Universidade de São Paulo

Faculdade de Filosofia, Letras e Ciências Humanas

Departamento de Letras Orientais

Programa de Pós-Graduação em Estudos Judaicos e Árabes

Milena de Mello Cassucci

Entre leões e tigres, entre chacais e raposos: aproximações entre poder e saber em fabulários

São Paulo 


\section{Universidade de São Paulo}

Faculdade de Filosofia, Letras e Ciências Humanas

Departamento de Letras Orientais

Programa de Pós-Graduação em Estudos Judaicos e Árabes

Entre leões e tigres, entre chacais e raposos: aproximações entre poder e saber em fabulários

Milena de Mello Cassucci

Dissertação apresentada ao Programa de Pós-Graduação em Estudos Judaicos e Árabes da Faculdade de Filosofia, Letras e Ciências Humanas da Universidade de São Paulo, para obtenção do título de Mestre em Estudos Árabes.

Orientador: Prof. Dr. Mamede Mustafa Jarouche

São Paulo 
Autorizo a reprodução e divulgação total deste trabalho, por qualquer meio convencional ou eletrônico, para fins de estudo e pesquisa, desde que citada a fonte.

\section{Catalogação da Publicação}


Para o Té e para o Mario.

Não chegaram a se conhecer, mas tenho certeza: teriam se gostado. 
AGRADECIMENTOS

À minha família.

Ao meu orientador, professor e amigo, Mamede Jarouche.

Ao meu namorado, melhor amigo e companheiro, Mario Rodas.

À minha amiga Juliana Cruz.

Aos meus amigos todos.

À Universidade de São Paulo.

Ao meu avô. 
Nada se encontra com procura ligeira;

deves, isso sim, lançar seu balde ao poço:

às vezes te virá cheio, mas em outras

te virá com lodo e bem pouca água.

(Abū Alaswad Addu'alī) 
Nome: CASSUCCI, Milena de Mello

Título: Entre leões e tigres, entre chacais e raposos: aproximações entre poder e saber em fabulários

Dissertação apresentada ao Programa de Pós-Graduação em Estudos Judaicos e Árabes da Faculdade de Filosofia, Letras e Ciências Humanas da Universidade de São Paulo, para obtenção do título de Mestre em Estudos Árabes.

Aprovado em:

Banca Examinadora

Prof. Dr.

Julgamento:

Instituição:

Assinatura:

Prof. Dr.

Julgamento:

Instituição:

Assinatura:

Prof. Dr.

Julgamento:

Instituição:

Assinatura: 


\section{RESUMO}

\section{CASSUCCI, M. M. Entre leões e tigres, entre chacais e raposos: aproximações entre poder}

e saber em fabulários. 2015. Dissertação (Mestrado). Faculdade de Filosofia, Letras e Ciências Humanas da Universidade de São Paulo. São Paulo, 2015.

A presente dissertação se propôs a analisar quatro fabulários, tendo como fio condutor dessa escolha o Kalīla e Dimna, fabulário árabe do século VIII d.C. Partindo desta obra, os estudos se orientaram tanto às suas origens, que remontam à compilação indiana Pañcatantra, datada do século I d.C. e que teve entrada no mundo árabe, bem como aos seus frutos, o Livro do tigre e do raposo e $O$ leão e o chacal Mergulhador, dois fabulários árabes produzidos, respectivamente, nos séculos IX d.C., XI d.C. e XII d.C. e que tiveram, em relação aos anteriores, menor disseminação. Os dois primeiros fabulários tratam de uma série de temas que podem atender às normas mais gerais de decoro na sociedade, sendo que o Pañcatantra chega até mesmo a ser classificado como um "tratado sobre a conduta" em manuais de literatura sânscrita. Entre esses temas diversos, é notável o espaço privilegiado dado às relações políticas e aos seus trâmites. Os outros dois livros, embora inseridos na mesma tradição, deixam de lado aspectos mais gerais da convivência e passam a se deter apenas nos temas especificamente políticos. No que se refere a esse assunto em comum, é possível perceber uma série de elementos recorrentes nos quatro fabulários, entre eles, o fato de que todos tratam das vicissitudes das relações entre poder e saber, personificada em personagens-tipo que ora se aproximam, ora se afastam, mas que se mantém atrelados a uma estrutura que os molda conforme os resultados que almeja atingir. Além disso, foram estudadas as estruturas - que, no caso, se apoiam na maior parte das vezes em "narrativas-quadro” ou "prólogos-moldura” a partir dos quais se desenvolvem subnarrativas - e outros elementos que nos possibilitaram, ao término do estudo, apontar o que há de particular na universalidade a que se propõem os fabulários.

Palavras-chave: literatura oriental, narrativas, fabulários, narrativas circulares, espelhos de príncipe. 


\begin{abstract}
CASSUCCI, M. M. Between lions and tigers, between jackals and foxes: relationships between power and knowledge in fable collections. 2015. Dissertation (Master's degree). Faculdade de Filosofia, Letras e Ciências Humanas da Universidade de São Paulo. São Paulo, 2015.
\end{abstract}

This dissertation aims to analyze four collections of fables, choosing as the central work from which further analysis will stem the Kalīla and Dimna, an Arab collection of fables dating from the VIII century A.D. From this starting point, these studies were furthered by revisiting its origins in the Panchatantra, an Indian compilation of fables from the I century A.D. that left its marks on the Arab world, as well as its developments in the books that directly follow its legacy, the "Livro do tigre e do raposo" and "O leão e o chacal Mergulhador", two arab collections of fables dating, respectively, to the IX century A.D. and the XI and XII century A.D. which had, however, far less dissemination than the last two works here cited. The first two collections develop around a variety of subjects relating to rules regulating manners in a broader sense, to the point that the Panchatantra has been classified as a "treatise on manners" in Sanskrit literature manuals. Between the diversity of subjects broached, the privileged attention given to political relations and their formalities is readily noticeable. The two other works, though part of the same literary tradition, set aside more general or day-to-day aspects of good manners to focus exclusively on political relations and political conduct. Regarding this shared thematic, a number of recurring elements can be identified, one of many being the fact that all of them deal with the specifics of the relationship stabilished between power and knowledge, personified in character types that alternate between approaching and distancing themselves from one another, but that are always attached to a structure that moulds them according to the results it desires. Beyond that, the narrative structures of the works were studied - they usually make use of frame narratives or "frame prologues" from which further subnarratives are developed - along with other elements that made it possible, at the end of this study, to point towards the particularities of the universality that the collections of fables undertake as their purpose.

Key-words: oriental narrative, narratives, fables, circular narrative, mirrors for princes. 


\section{Lista de figuras}

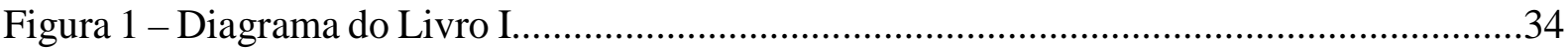

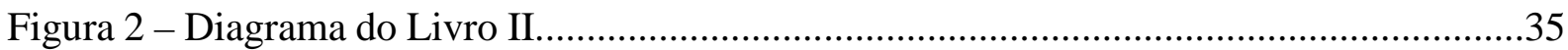

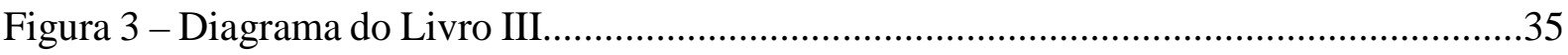

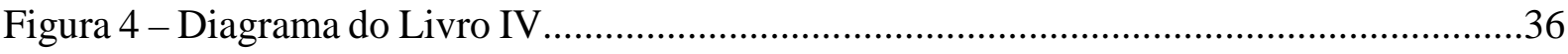

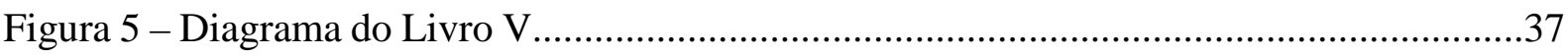

Figura 6 - Diagrama do capítulo I - O leão e o touro..............................................................65

Figura 7 - Diagrama do capítulo II - Investigação acerca de Dimna.......................................67

Figura 8 - Diagrama do capítulo III - A pomba de colar.......................................................68

Figura 9 - Diagrama do capítulo IV - Os corujões e os corvos...............................................69

Figura 10 - Diagrama do capítulo V - O macaco e o cágado...................................................70

Figura 11 - Diagrama do capítulo VI - O devoto e o mangusto................................................71

Figura 12 - Diagrama do capítulo VII - Iblād, Īrāhnt e Xārdam, rei da Índia..............................71

Figura 13 - Diagrama do capítulo VIII - Mihrãyaz, o rei dos ratos.........................................72

Figura 14 - Diagrama do capítulo XI - O asceta e o hospede..................................................73 


\section{Sumário}

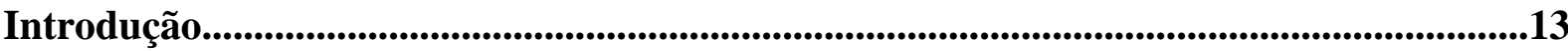

Capítulo I - Sobre o Pañcatantra.............................................................................24

Estabelecendo relações - Pañcatantra e Kalīla e Dimna.........................................................24

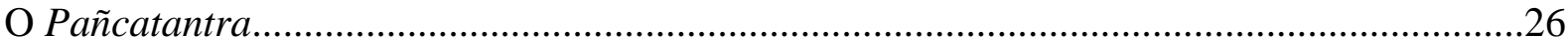

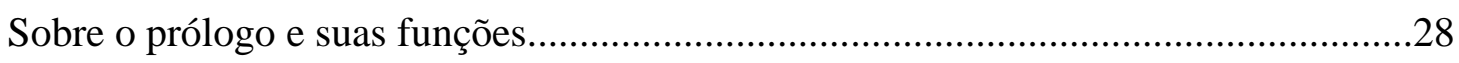

A narrativa-quadro ou prólogo-moldura....................................................................32

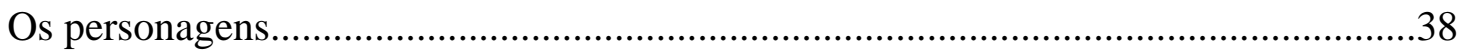

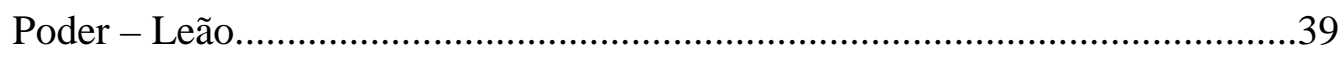

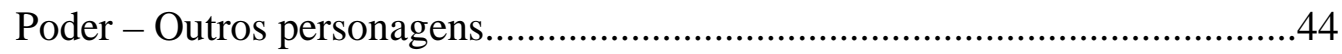

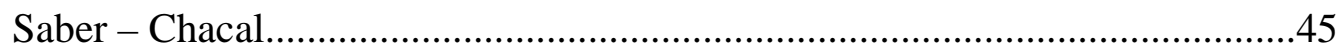

Capítulo II - Sobre o livro de Kalīla e Dimna.......................................................................50

Dois chacais: sagacidade e decoro ao invés de cinco tratados sobre a conduta........................50

Um único Deus para Kalīla e Dimna......................................................................52

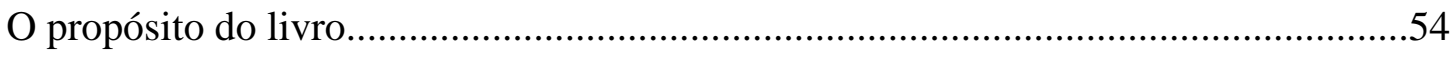

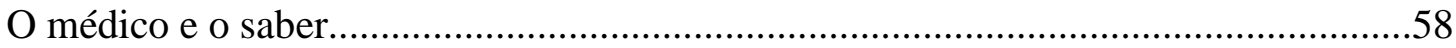

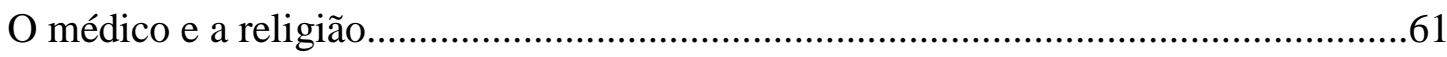

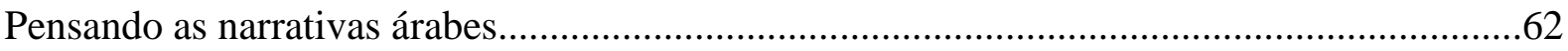

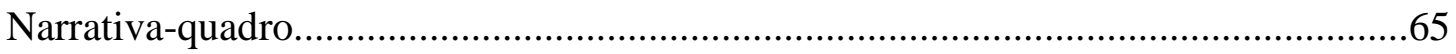

Das semelhanças - Prólogo para o estudo dos personagens..................................................73

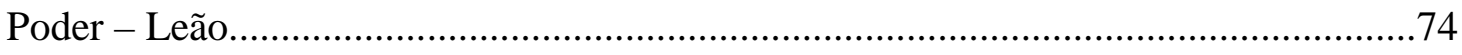

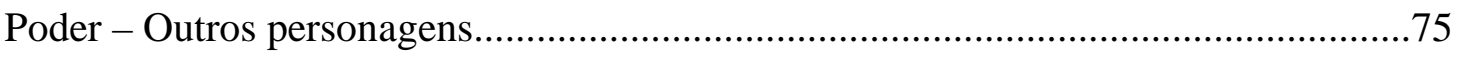

Os personagens masculinos humanos e suas ocorrências................................75 
Saber - Chacal.

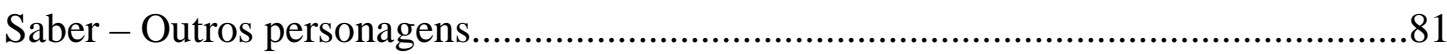

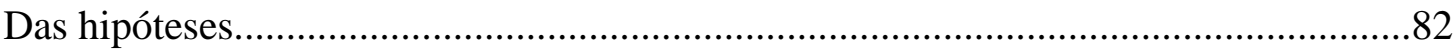

Capítulo III - Sobre O leão e o chacal Mergulhador e o Livro do tigre e do raposo............83

Estabelecendo novas relações - dando continuidade à tradição............................................83

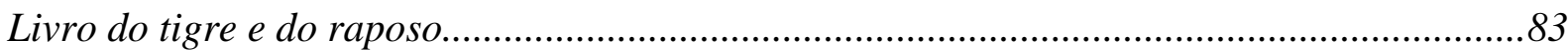

Sobre os personagens - O leão, o tigre e as novas representações de poder.................87

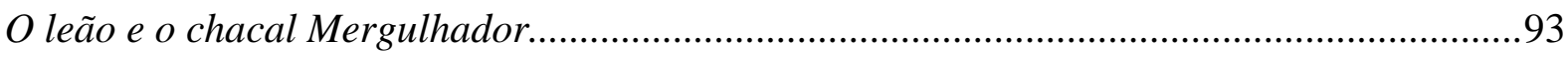

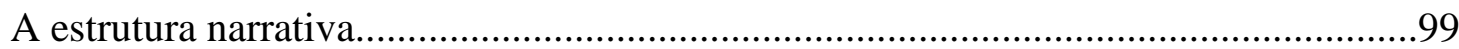

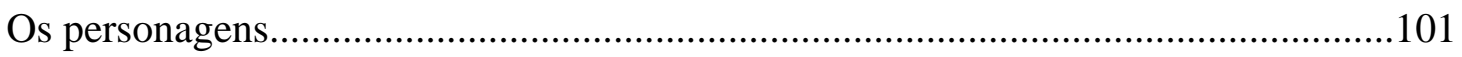

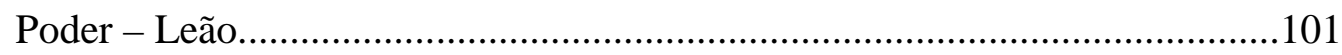

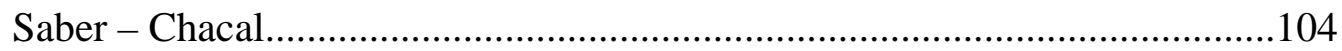

Capítulo IV - Discussões...............................................................................................109

Contexto histórico em que os fabulários se inserem..............................................................109

Pañcatantra - A Índia do século XV a.C. ao I d.C..................................................109

Kalīla e Dimna - O Irã do século VI d.C. ao VIII d.C...............................................114

O livro do tigre e do raposo - O Irã do século VIII d.C. ao IX d.C...........................117

O leão e o chacal Mergulhador - O Irã do século IX d.C ao XI d.C..........................120

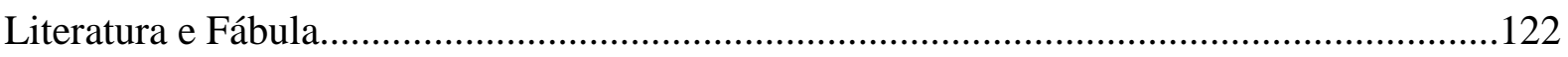

A fábula - definições e considerações...................................................................123

Apontamentos diversos sobre os fabulários.........................................................133

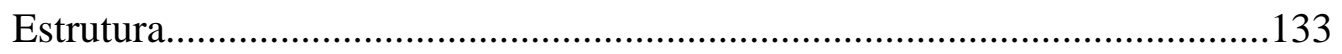

Traduções, versões e apagamentos - Sobre narrativas e soberanos.................139

Por quê e por quem: o que ainda se pode dizer sobre as fábulas....................140 


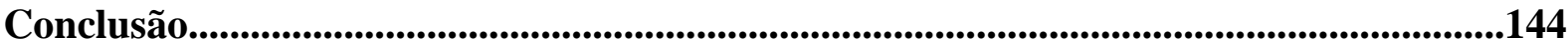

Referências bibliográficas...............................................................................................148 


\section{Introdução}

O livro de Kalīla e Dimna, obra inscrita na cultura árabe-islâmica cuja composição data, segundo a tradição, aproximadamente do século VIII d.C., é de inegável importância: traduzido em diversos idiomas repetidas vezes e amplamente disseminado tanto no Oriente como no Ocidente $^{1}$, é considerado, ao lado de obras como o Pañcatantra e as fábulas de Esopo, uma respeitável referência do fabulário universal. ${ }^{2}$

Tamanha importância, no entanto, não isenta o fabulário de ser objeto de uma série de discussões e contendas que envolvem desde suas fontes e origens até a sua autoria. Com uma estrutura principal e uma série de narrativas originárias da Índia e atribuídas à epopeia Mahãbhãrata e ao Pañcatantra - que, por sua vez, foi reelaborado em um texto perdido em pehlevi - Kalīla e Dimna é conferido - não sem uma série de discussões - ao escriba 'Abdullah Ibn-Almuqaffa ${ }^{\mathrm{c}}$, que, segundo alguns estudiosos, teria se baseado sem obrigatória fidelidade ${ }^{3}$ na versão pehlevi e inserido algumas narrativas de circulação no mundo islâmico na sua composição ${ }^{4}$. Assim, há quem considere, de modo bastante depreciativo, o fabulário árabe como uma simples tradução do compêndio de apólogos indianos Pañcatantra ou que julgue 'Abdullah Ibn-Almuqaffa ${ }^{\mathrm{C}}$ como um simples copista, além daqueles que lhe recusam inclusive essa função, negando-lhe a autoria ${ }^{5}$. Ao nos determos mais aprofundadamente nos estudos do livro de Kalīla e Dimna podemos perceber que nem sequer a sua recepção entre os antigos árabes era unânime, posto que muitos eram os estudiosos de diversas áreas que o consideravam

\footnotetext{
${ }^{1} \mathrm{O}$ livro de Kalīla e Dimna foi traduzido a uma grande variedade de idiomas, da qual é possível destacar, entre as línguas ocidentais, o grego (século X), latim (séculos VII, XVI), espanhol (séculos XIII, XV, XVII e XVIII) e italiano (século XVI). A maioria das traduções foram feitas do árabe ou de alguma tradução do árabe, produzindo uma extensa cadeia de transmissão.

${ }^{2}$ IBN ALMUQAFFAc, Kalīla e Dimna. Tradução, organização, introdução e notas de Mamede Mustafa Jarouche. São Paulo: Biblioteca Martins Fontes, 2005, p. 17.

${ }^{3}$ Segundo Lancereau "L'exemplaire de la version pehlvie dont Abdallah s'était servi est perdu, et l'on ignore si le traducteur en a suivi fidèlement le texte”. ANÔNIMO. Pañcatantra. Tradução de Edouard Lancereau. Paris: Éditions Gallimard/UNESCO, 1965, p. 27.

${ }^{4}$ Conforme é possível constatar no levantamento realizado por Mamede Jarouche na introdução Vicissitudes de um livro e de seu autor, há fábulas inseridas nos capítulos II, XV, XVI e XVII no livro de Kalīla e Dimna que são da tradição árabe-muçulmana, não encontrando correspondência em nenhum outro fabulário indiano ou de outra fonte. IBN ALMUQAFFAc, Kalīla e Dimna. Tradução, organização, introdução e notas de Mamede Mustafa Jarouche. São Paulo: Biblioteca Martins Fontes, 2005.

${ }^{5}$ Há, segundo o jesuíta turco-libanês Luis Cheikho, um manuscrito datado de 1447 d.C. que atribui a tradução do Kalīla e Dimna do persa ao árabe a 'Abdullah Ibn 'Ali Al'ahwazi, e não a 'Abdullah Ibn-Almuqaffac. CHEIKHO, 1905, apud JAROUCHE, 2005.
} 
uma obra de qualidade discutível ${ }^{6}$, havendo, inclusive, obras que deliberadamente buscaram superá-lo, tal como um dos fabulários estudados nesta dissertação, O livro do tigre e do raposo.

É adequado dizer, no entanto, que, independentemente da origem ou originalidade da obra, foi o fabulário árabe que teve maior penetração no Ocidente, graças a um sem número de traduções e versões, e que foi a partir dele que tais narrativas foram disseminadas mundo afora. Também vale dizer que, se considerarmos o número de citações - positivas ou não - de Kalīla e Dimna entre os autores e estudiosos de sua época e, além disso, o número de obras que vieram ou em uma tentativa de superá-lo, ou baseados em seu modelo, somos obrigados a reconhecer a relevância que o fabulário teve não apenas em sua época, mas que se mantém através do tempo.

Alguns autores atribuem a importância dessa obra a uma suposta maior riqueza textual da versão árabe em relação a indiana. Com efeito, pode-se dizer que o fabulário árabe possui estrutura narrativa bastante complexa, que pode ser definida atualmente como estrutura-emcadeia ou narrativa circular, em que há um eixo principal (ou um prólogo-moldura) de onde partirão diversas outras narrativas, que podem dar origem a inúmeros níveis ou camadas de fábulas num desenvolvimento que ora ou outra culminará no retorno à narrativa original. Embora o fabulário indiano também apresente essa estrutura narrativa - e talvez possa ser considerado, senão o primeiro a utilizá-la, um dos percussores de tal estratégia -, é possível verificar que o fabulário árabe faz um uso mais sofisticado e menos ritualizado da estruturaem-cadeia, que influencia diretamente a leitura, tornando-a mais fluída e prazerosa. Considerando que ambas as obras tiveram forte circulação oral, podemos sugerir superficialmente, posto que voltaremos a desenvolver o assunto aprofundadamente adiante que lançavam mão de diferentes estratégias tanto para fins de memorização como para mesmerizar o público. Considera-se inclusive que o contato com a estratégia utilizada de forma tão bem-sucedida em Kalīla e Dimna possa ter influenciado, mais tarde, As mil e uma noites considerada um cânone da literatura ocidental e uma das obras fundamentais do gênero maravilhoso $^{7}$-, na qual se observam os mesmos prólogo-moldura e estrutura-em-cadeia. Novamente, revela-se evidente a importância do fabulário que, de um modo ou outro, contribuiu

\footnotetext{
${ }^{6}$ Segundo Jarouche "o prestígio do formato de fábula de Kalīla e Dimna parece ter sido relativizado, ao menos entre os letrados, pela rejeição a esse gênero, a despeito da recorrente citação de suas máximas, numa evidente citação de desapreço [...]”. ANÔNIMO. O leão e o chacal Mergulhador. Tradução de Mamede Mustafa Jarouche. São Paulo: Editora Globo, 2009, p. 200.

${ }^{7}$ TODOROV, T. As estruturas narrativas, São Paulo: Editora Perspectiva, 1970, p. 121.
} 
e contribui não apenas no que se refere a um procedimento, mas também na construção de um escopo de literatura maravilhosa ${ }^{8}$.

Um outro elemento que pode ser responsável pela importância e disseminação da obra é o fato de que ela aborda de modo agradável - ou deleitoso, como nos aponta seu suposto autor $^{9}$ - uma gama bastante ampla de temas que podem ser agrupados sob um grande mote: o viver em sociedade. Assim como ocorre na obra indiana, do livro de Kalīla e Dimna é possível depreender uma série de situações exemplares que podem ser aplicadas ao cotidiano, em um caráter de universalidade que, ao se utilizar de personagens sem tempo ou sem nome, podem servir, consequentemente, a qualquer tempo, a qualquer um de nós, submetidos a um viver em grupo que pressupõe certas regras, organizações e hierarquias. Cabe destacar, no entanto, que, dentre os temas tratados, há um que se sobressai, se não ao longo de todo o livro, inegavelmente nos dois primeiros capítulos: a política. Segundo o tradutor Mansour Chalita, o livro de Kalīla e Dimna "contém realmente, toda a sabedoria humana, orientada para a mais prestigiosa e influente das atividades: a política, a arte de governar, de guiar o destino dos homens e dos povos e de moldá-los pouco a pouco conforme convicções e concepções próprias” ${ }^{10}$ e, de fato, os liames da política são trabalhados e apresentados de modo esmerado em diversas das fábulas que compõem a obra, encontrando em O leão e o touro (capítulo análogo ao Livro I do Pañcatantra, A desunião de amigos) e Investigação acerca de Dimna um espaço de desenvolvimento privilegiado.

O título do fabulário, Kalīla e Dimna, além de se relacionar metonimicamente com a obra - já que se trata justamente dos nomes de dois personagens bastante importantes dos dois primeiros capítulos/prólogos-moldura - é a forma arabizada, a partir do pehlevi, do nome de dois personagens do Pañcatantra, Karațaka e Damanaka ${ }^{11}$, chacais que têm participação importante no desenvolvimento do prólogo-moldura do Livro I do fabulário indiano, A

\footnotetext{
${ }^{8} \mathrm{O}$ termo literatura maravilhosa está relacionado ao uso dado por Tzvetan Todorov em obras como As estruturas narrativas, Teoria da Literatura e Introdução à literatura fantástica. Oportunamente, será verificado cuidadosamente e discutido, sobretudo a respeito de sua pertinente utilização ou não nas obras estudadas.

${ }^{9}$ Segundo Ibn-Almuqaffac “[...] o livro, reuniu sabedoria e diversão. Os sábios elegeram-no por causa da sabedoria, e os néscios, por causa da diversão”. IBN ALMUQAFFA', Kalīla e Dimna. Tradução, organização, introdução e notas de Mamede Mustafa Jarouche. São Paulo: Biblioteca Martins Fontes, 2005, p. 5.

${ }^{10}$ IBN AL-MUQAFFA ${ }^{c}$. Calila e Dimna. tradução de Mansour Challita, São Paulo: Catavento Distribuidora de Livros S/A, 1975. Note-se, ainda, que a tradução latina de Jean de Capua intitulou-se Directorium Vitae Humanae, ou seja, "guia da vida humana".

${ }^{11}$ Os nomes dos chacais do fabulário Karațaka, "gralha" e Damanaka, "domador" - que dizem muito a respeito dos personagens, principalmente o de Damanaka que, literalmente doma o leão e o manipula conforme seus interesses - foram provavelmente adaptados ao árabe por meio de corruptelas do persa, chegando aos nomes que intitulam o fabulário árabe, Calila e Dimna.
} 
desunião de amigos. Tal alusão aponta para algo que talvez não estivesse tão claro no fabulário indiano: os dois mencionados primeiros capítulos nos quais figuram Kalīla e Dimna, outrora Karațaka e Damanaka, além de serem de proeminente temática política têm - talvez justamente por esse motivo - muita importância, chegando a nomear a obra. Vale lembrar que os dois personagens que intitulam a obra são construídos como detentores de saber e se dispõem a uma arriscada tentativa de proximidade com o leão, personagem ao qual é atribuído o poder soberano. Assim, saber e poder travam, nos dois primeiros capítulos da obra, uma delicada aproximação que trará consequências a ambos, enquanto o leitor entra em contato com uma floresta fictícia e alegórica que espelha as relações do rei com seus súditos e dos jogos políticos que marcam essa dinâmica.

O livro de Kalīla e Dimna pode, ademais, ser considerado como um dos primeiros exemplares do que seria definido posteriormente como fabulário político, devido à temática que permeia grande parte de suas narrativas: por meio de uma série de reflexões morais e políticas delineiam-se as relações de poder entre aqueles que não o detêm e o almejam e aqueles que necessitam (e desejam) mantê-lo ou aumentá-lo. Esse fabulário teria influenciado a composição de muitos outros com semelhantes características - em alguns casos mais voltados para o aspecto pedagógico que literário -, os quais teriam, por sua vez, relação com os Specula principum (espelhos de príncipes), gênero de obras deveras prolífico, produzido não apenas na cultura árabe, mas também no Ocidente a partir do século IX até o século XVI d.C., já em pleno Renascimento ocidental. A mais conhecida entre elas é O Príncipe ${ }^{12}$, de Maquiavel.

Além de tudo que já fora dito, graças às diversas traduções, versões e adaptações, o Kalīla e Dimna ficou conhecido mundo afora e teve influência na composição de diversos outros fabulários, conforme podemos observar na passagem:

[...] título que não abarca o conteúdo dos dezoito livros da coleção, uma vez que se refere apenas aos nomes dos dois personagens principais (Karațaka e Damanaka, em sânscrito) do primeiro livro do Pañcatantra, [Kalīla e Dimna] pode ser considerada como fonte de muitas coleções de fábulas que se manifestaram na Idade Média e que, posteriormente, forneceram material para a composição dos Livros VII a XI de Fables de La Fontaine.

Deve-se também considerar que, ao lado dessa tradição da fábula indiana, a tradição da fábula grega (esópica) passava, na Idade Média, a ter papel fundamental na consolidação desse gênero literário. É, aliás, do encontro das duas tradições - a esópica e a indiana - que a fábula vai adquirir o modelo que será adotado pelos fabulistas posteriores, entre eles La Fontaine e Monteiro Lobato. ${ }^{13}$

\footnotetext{
${ }^{12}$ O Príncipe teve a sua primeira versão em 1.513, porém, foi publicado apenas em 1.532 .

${ }^{13}$ ANÔNIMO. Pañcatantra: Fábulas Indianas - Livro I. Tradução de Maria da Graça Tesheimer; Maria Valíria Aderson de Mello Vargas; Marianne Erps Fleming. 2. Ed. São Paulo: Humanitas, 2004, p. 11.
} 
Dada não apenas a sua importância histórica para disseminação e fixação do gênero, mas também sua complexidade estrutural, o Kalīla e Dimna pode ser estudado sob diversos recortes e justificativas, e, aqui nesta dissertação, será estudado tanto em relação às suas características particulares como em comparação a outros que se relacionam a ele em uma tradição, especialmente sob aspectos que serão apresentados adiante, após a exposição das obras que também farão parte deste estudo.

Conforme já fora citado e possivelmente observado até o momento, também a importância do Pañcatantra não pode ser diminuída, pois o fabulário árabe, embora tenha inegáveis méritos e características muito próprias (e que serão melhor discutidos ao longo deste trabalho) entabula uma série de relações com o compêndio indiano que, se ignoradas, influenciam negativamente na sua leitura e interpretação. Assim, consideramos adequado nos deter em uma análise pormenorizada do Pañcatantra, inclusive para que possamos apontar com maior propriedade em que pontos o fabulário árabe o reafirma e em quais outros toma a liberdade de trilhar diferentes caminhos, sem que isso represente, contudo, um prejuízo à tradição em que passa a se inserir. Inscritos em culturas que, embora mantenham certo diálogo em alguns aspectos, apresentam, entre si, diferenças bastante contundentes, os fabulários são produzidos também em contextos históricos diversos, o que possivelmente pode provocar interferências nas composições, conforme se pretende verificar. Como já dito, o Pañcatantra é tido por muitos estudiosos como uma espécie de matriz para o livro de Kalīla e Dimna e as relações entabuladas entre as duas obras - que serão melhor explicitadas no decorrer do trabalho - vão desde a estrutura-em-cadeia já mencionada, até os personagens e as fábulas contadas. Vale ressaltar aqui que os dois compêndios apresentam, não obstante, diferenças e matizes entre um e outro que tornam ambas as leituras essenciais para quem quer que deseje entender mais sobre fabulários.

Classificados como manuais de conduta ${ }^{14}$, os cinco livros que compõem o Pañcatantra tratam de temas diversos além da política, e lidam com esses temas de forma a oferecer a quem lê orientações de conduta. É possível observar, inclusive, que nessa orientação ele difere do

\footnotetext{
${ }^{14}$ Foram encontradas duas traduções possíveis para o termo sânscrito nîtisâstra, a saber: manual de conduta; segundo Lancereau (1965), nîti significa conduta ou arte de se conduzir e sâstra significa manual/livro de ciência. Dessa forma, temos tanto traduções que indicam o Pañcatantra como um manual de conduta ou como um tratado sobre política ou sobre a arte de governar. Assim, teríamos, ao considerar a segunda possibilidade de tradução, a associação direta do fabulário indiano à política desde o seu momento de produção. Embora o livro de Kalīla e Dimna tenha aspectos acentuadamente políticos, não foi assim considerado pela crítica de sua época, evidenciando diferentes contextos de leitura e recepção.
} 
fabulário árabe, sugerindo diferenças na construção moralizante de cada sociedade. Se em determinadas fábulas não cabe punição no compêndio indiano, o livro de Kalīla e Dimna já sugere outras possibilidades de desfecho e, em contrapartida, fábulas árabes em que aquele que realiza determinada artimanha é bem-sucedido não encontram espelho no Pañcatantra, trazendo, por vezes, a mesma fábula, mas com um desenlace completamente diferente. Há, ainda, a possibilidade de mudança de ações de um personagem-tipo para outro ${ }^{15}$, e pretendemos apontar hipóteses para a variação dessa utilização, conforme seguirá.

Inserido na mesma tradição literária que alinha as já mencionadas obras e posterior, nessa ordem, ao Kalīla e Dimna, também está o Livro do tigre e do raposo, que, embora apresente muitas diferenças, a começar pelo título - que traz como personagens-tema animais ou inexistentes ou pouco relevantes nos dois outros fabulários -, possui uma série de elementos essenciais que o associam especialmente ao livro de Kalīla e Dimna. Produzido como tentativa de superar o seu antecessor árabe, o Livro do tigre e do raposo já se destaca ao abrir mão das subnarrativas (ou narrativas encaixadas) para apresentar uma narrativa planiforme e mais linear, simplificada, mas que ao mesmo tempo já exige de saída um leitor/receptor com conhecimentos prévios - destoando novamente de seus predecessores, que, pelo contrário, almejavam e declaravam a intenção de alcançar como público não apenas os sábios, mas também os néscios ${ }^{16}$ -, desenvolvendo uma sequência de enredo que, embora destoe dos outros fabulários estudados, apresenta, ainda, pontos importantes de aproximação: há, tal como em Pañcatantra e Kalīla e Dimna, uma relação entre poder e saber que se estabelece em um panorama escancaradamente político e que oferece risco, principalmente àquele que ocupa a posição de saber.

Curiosamente, o Livro do tigre e do raposo deixa de lado os temas que, concernentes ao viver em sociedade, não se relacionam à política. Outrora tratados, se não com equivalente importância, com reconhecida presteza e abordagem interessada, assuntos como a manutenção da amizade são descartados e dão lugar a diálogos que expõem estratégias belicosas e realçam o caráter político do fabulário.

Elaborado entre os séculos XI d.C. e XII d.C., O leão e o chacal Mergulhador, assim com os demais fabulários elencados, tem aqui sua presença e estudo justificados por se tratar

\footnotetext{
${ }^{15}$ Há fábulas que serão estudadas adiante em que se observará que, comparativamente, animais diferentes praticam ações na obra indiana e na obra árabe. Podemos adiantar aqui o exemplo das fábulas respectivamente indiana e árabe: O leão o camelo, o lobo, o chacal e o corvo e “O leão Madotkața”, em que chacal e corvo trocam de função. 16 Tanto o Pañcatantra como o livro de Kalīla e Dimna anunciam em seus prólogos que se voltam àqueles que precisam aprender muito em pouco tempo, aos jovens do mundo (versão indiana) e aos néscios (versão árabe).
} 
de uma obra já inserida em uma tradição consolidada e que, além disso, passa a ser classificada como híbrida entre fabulário e tratado político, expondo um caminho que já se vislumbrava em Kalīla e Dimna e que é reforçado no Livro do tigre e do raposo. Claramente inspirada no Kalīla e Dimna, traz novamente um panorama político em que uma floresta alegórica passa a ser palco de uma série de tramas e articulações políticas de favorecimento e trapaças, na qual outra vez poder e saber travam relações que se revelam daninhas, aqui alvos de inveja e maldizer. As questões políticas passam a assumir uma importância privilegiada e as narrativas ficcionais, que antes tinham sua importância e qualidade relativizadas pelos estudiosos, passam a figurar - não sem antes passar por alterações que serão devidamente apontadas - como leituras necessárias para se alcançar êxito, tanto nas relações com o poderio como na manutenção dos benefícios adquiridos, além de servirem também aos potentados.

Uma outra obra que pode ser mencionada no que se refere aos aspectos que serão estudados é Sindabâd ou Os sete vizires, texto originalmente indiano ${ }^{17}$ que, apesar de ter tido seus originais em sânscrito perdidos, continuou a ser transmitido em versões de outras línguas, entre elas o árabe. No fabulário, as mesmas relações entre poder e saber são abordadas, expondo a possibilidade de o soberano ser posto em risco dentro de sua própria corte, caso seus agregados não sejam confiáveis. O rei pode vir a perder o poder tanto pela traição dos seus como pelos próprios erros e, para que se proteja dessa possibilidade, é fundamental que se aproxime de quem possa lhe dar conselhos acertados, ou seja, daqueles providos de saber. Assim como o livro de Kalīla e Dimna, Os sete vizires também foi bastante disseminado, chegando à Península Ibérica a partir de versões traduzidas diretamente do texto árabe e é tido em alta conta, por ser considerado um dos percussores dos contos de fadas tal como os conhecemos. As fábulas dele diferem das demais pois, de modo diverso do corrente, apresentam a maioria de seus personagens como humanos - embora ainda sem maiores definições que pudessem particularizá-los - e não animais antropomorfizados. Vale apontar que a transmissão através dos tempos acabou por assimilar essas fábulas ao corpus de As mil e uma noites ${ }^{18}$, mas, apesar

\footnotetext{
${ }^{17}$ Maçoudi, historiador do século X indica a Índia como berço desta obra, assim como de Hézar Afsaneh (Os mil contos), que seria, posteriormente, conhecida como As mil e uma noites. ANÔNIMO. Pañcatantra. Tradução de Edouard Lancereau. Paris: Éditions Gallimard/UNESCO, 1965, p. 38.

${ }_{18}$ De fato, ao verificarmos o terceiro volume de As mil e uma noites traduzido por Mamede Jarouche, nos deparamos com a vigésima quarta noite do mês e entramos em contato com a fábula $\mathbf{O}$ rei e a esposa de seu secretário (pg. 293), que, segundo notas do tradutor, seria uma apropriação de um dos relatos constantes em Os sete vizires. Vale expor ainda o relato que relaciona as duas obras "Das crônicas [o filho do rei] deve decorar as [conquistas do islã], as biografias [de reis] e as coisas sucedidas aos califas, e não aos amantes, nem as tolices do Livro de Sindabâd, Hazâr Afsân [Mil fábulas] e assemelhados, pois com esses livros ele se distrai, porém mais deforma que se forma [...]". Abū Bakr Assuli. Livro das folhas. Cairo, 1935. Apud: ANÔNIMO. O leão e o chacal Mergulhador. Tradução de Mamede Mustafa Jarouche. São Paulo: Editora Globo, 2009.
} 
disso, não deixaram de circular autonomamente e afirmar sua importância ao longo do tempo, tendo sua relevância atestada inclusive na literatura medieval espanhola, onde chegou através de traduções feitas diretamente do árabe a mando de Dom Fadrique, irmão de Afonso X, o sábio.

Expostos os livros que servirão de base para a produção desta dissertação, apresentamos agora nossos objetivos: situar as obras mencionadas histórica e literariamente, além de assinalar de forma mais aprofundada as relações brevemente delineadas entre elas; apontar traços compositivos de cada obra explicitando semelhanças e diferenças; sugerir hipóteses para determinadas composições e funções de certos personagens que se apresentam ou como recorrentes ou como detentores de funções-chave, trabalhando o conceito de personagem-tipo; sugerir proposições para a solução de problemas teóricos de interpretação moral de certas fábulas. Alcançados esses objetivos, pretende-se ainda delinear o que seja uma ideia de gênero do discurso, sua caracterização e identificação de certas constâncias formais e temáticas. Quais traços compositivos seria necessário respeitar para que fossem cumpridos os efeitos de pertencimento esperados e quais seriam os aspectos que, em contrapartida, poderiam ser flexibilizados sem que isso causasse, por consequência, uma descaracterização ou desligamento do gênero.

Para tanto, serão estudados, predominante e aprofundadamente, o primeiro dos cinco livros que constituem o Pañcatantra, intitulado A desunião de amigos, os primeiros dois capítulos do Kalīla e Dimna, respectivamente O leão e o touro e Investigação acerca de Dimna $^{19}$, o Livro do tigre e do raposo e O leão e o chacal Mergulhador. Apenas quando necessário se recorrerá aos outros livros do Pañcatantra e ao restante do Kalīla e Dimna; essa opção se faz, de início, pelo fato de os capítulos e livros citados terem em comum uma narrativa na qual, irremediavelmente, poder e saber se relacionam estreitamente - e é dessa relação que todo o restante advém - e também pelo fato de que esse material já traz consigo uma infinidade de elementos a ser analisada e que muito contribui para os estudos e para formulações acerca do gênero abordado. Além disso, vale lembrar que, embora as obras todas sejam constituídas de muitos elementos importantes para a compreensão sobre os fabulários e que, ao

\footnotetext{
19 Aqui é adequado dizer, para fins didáticos: optamos por colocar os capítulos das obras em negrito para diferenciá-los das fábulas, pois muita vez nós nos referiremos a certos nomes ora fábulas, ora como capítulos, como acontece com “O leão e o touro”, por exemplo, já que o mesmo nome pode servir para identificar o primeiro capítulo do livro de Kalīla e Dimna e, ao mesmo tempo, a narrativa-quadro de uma fábula de mesmo nome e no qual se encaixam diversas outras subnarrativas.
} 
estabelecermos um recorte que deixa de fora certos livros e capítulos, deixamos também de lado possibilidades de entendimento, também é necessário nos adequarmos à natureza sucinta de um mestrado, e acreditamos que já os capítulos e livros selecionados nos trarão elementos bastante relevantes. O fabulário Sindabâd ou Os sete vizires, embora bastante relevante na tradição, não será estudado especificamente, mas utilizado de aporte quando necessário, dada a já ampla quantidade de livros estudados.

É necessário antecipar, contudo, que ao menos em dois momentos não será possível evitar o contato com a completude do Pañcatantra e o Kalīla e Dimna: o primeiro, quando, ao estudar as duas obras comparativamente, tratarmos das estruturas narrativas que conduzem uma e outra em comum e que justificam uma análise detalhada tanto por se diferenciarem das outras duas obras - que apresentam narrativas mais simplificadas, uma delas inclusive planiforme -, como pela complexidade de elaboração e importância que têm na tradição literária, servindo, como já fora mencionado, de precursoras/influenciadoras de clássicos como As mil e uma noites. O segundo momento, quando, ao iniciarmos o exame detalhado dos personagens, nos depararmos com a recorrência de personagens-tipo cuja importância se verifica, além dos papéis/funções que ocupam, justamente na repetição: é por meio dela que podemos apontar elementos estruturais/constitutivos, ou seja, só podemos dizer que o leão é uma alegoria do poder porque ele aparece, repetidas vezes, como detentor deste papel. Assim, será necessário o levantamento de todos os momentos em que este e outros personagens que se almeja estudar aparecem para que sejam construídas hipóteses para os seus funcionamentos.

No que se refere ao estudo das características que constituem os personagens e compõem suas funções, ainda é necessário dizer que os fabulários são povoados por uma série tão diversa de personagens que elencá-los e detalhá-los, embora não fosse impossível, mais uma vez não atenderia aos propósitos tão concisos que um mestrado contempla. Por conta disso, optamos por um novo recorte que é avaliado adequado: considerando que, ao nos determos nos livros e capítulos previamente selecionados, é possível apontar personagens que possuem importância elevada, seja por conduzirem as ações ou por serem elementos motivadores para tomada dessas ações, serão esses os personagens que, carregados de significância, também aqui receberão atenção mais dedicada. Assim, podemos apontar, a priori, os personagens-tipo chacal, leão, tigre e raposo, pois entabulam as principais relações ente poder e saber, mas, no estudo de cada obra, poderão surgir outros personagens que chamarão para si a importância e, assim, justificarão seu posterior detalhamento neste trabalho. 
Antes de iniciarmos este estudo, é necessário fazer um último apontamento: dadas as características de produção e disseminação das obras que serão analisadas, há uma série de versões e traduções para cada uma delas, e, dentre essas inúmeras possibilidades de acesso aos fabulários, há notáveis diferenças de uma versão para outra, de um caminho de tradução para outro. O livro de Kalīla e Dimna, por exemplo, possui uma série de manuscritos bastante dissonantes entre si, que podem ser divididos em seis diferentes famílias ${ }^{20}$ e chegam ao ponto de tornar impossível uma edição crítica ${ }^{21}$; cada uma dessas famílias teve suas traduções e, por conta disso, é possível perceber nítidas variações nas histórias conforme a versão e edição que se consulta, sendo que a mesma situação se repete em relação ao Pañcatantra. No caso do Livro do tigre e do raposo e O leão e o chacal Mergulhador, a situação é diferente, e nem por isso melhor: o primeiro chegou aos dias de hoje relativamente inteiriço ${ }^{22}$, com poucas discussões circunscritas a trechos determinados, e o segundo, dada a limitada disseminação, conta com apenas dois ou três manuscritos em relativo bom estado para consulta ${ }^{23}$; há, no entanto, uma grande dificuldade de se encontrar traduções dessas obras, diretamente relacionada à restrita circulação delas.

Levando essas características peculiares em consideração, adotaremos versões principais nas quais nos basearemos para os estudos, sem, com isso, nos furtarmos a buscar, sempre que possível, a verificação de outras possibilidades de desenvolvimento e outras traduções das obras. Tendo em vista ainda o fato de que há respeitáveis traduções diretas para o português dos quatro fabulários, nos concentraremos nessas leituras, que são as seguintes:

- Pañcatantra: Tradução direta do sânscrito por Maria da Graça Tesheiner, Marianne Erps Fleming e Marília Valíria Aderson de Mello Vargas²4;

- Kalīla e Dimna: Tradução direta do árabe por Mamede Mustafa Jarouche ${ }^{25}$;

\footnotetext{
${ }^{20}$ SPRENGLING, M. "Kalīla Studies. I”, in: The American Journal os Semitic Languages and Literatures, 1924, apud JAROUCHE, 2005.

${ }^{21}$ Fala-se aqui, num sentido bem tradicional e hoje considerado superado por parte da crítica filológica, da edição dita lachmaniana.

${ }^{22} \mathrm{O}$ manuscrito aparentemente completo do referido livro foi encontrado na Tunísia na década de 60 .

${ }^{23}$ Foram encontrados dois manuscritos do livro no Egito e um na Î́ndia, sendo que o mais antigo deles, egípcio, data de 1543 d.C.

${ }^{24}$ As autoras fazem a tradução a partir da edição em sânscrito de Kâle (Pañcatantra of Viṣnuçarman) publicada por Motilal Banarsidass Publishers Ltd. e se utilizam também de G. Bühler como edição de apoio.

${ }^{25}$ A tradução utilizou a edição de ${ }^{\mathrm{C}}$ Abdulwahhāb ${ }^{\mathrm{C}} \mathrm{Azzām}$, derivada do manuscrito mais antigo, de 1221 d.C., valendo-se tanto da primeira edição, de 1941, quanto da segunda, de 1973. Utilizou-se também como edições de apoio a edição do jesuíta turco-libanês Luis Cheiko, por ser baseada em um manuscrito também antigo, de 1339 d.C., a edição de 'Aḥmad Ḥasan Tabbāra, baseada em um manuscrito de 1675 d.C. e a edição do Cairo, última revisão de 'Ibrāhīm Addasūqī c Abdulg̀affār, em 1868 d.C., baseada na edição criticada do arabista francês Silvestre de Sacy.
} 
- Livro do tigre e do raposo: Tradução direta do árabe por Mamede Mustafa Jarouche ${ }^{26}$;

- O leão e o chacal Mergulhador: Tradução direta do árabe por Mamede Mustafa Jarouche ${ }^{27}$.

${ }^{26}$ A obra é traduzida a partir da fixação em árabe do manuscrito descoberto por cAbdulqādir Almahīrī na década de 1960, publicada em 1973 pela Universidade da Tunísia.

${ }^{27} \mathrm{O}$ autor se vale, em sua tradução, do manuscrito n. 1825, Khuda Bakhsh, descoberto na cidade de Patne por Raḍ̂ān Assayyid, pesquisador da Universidade Libanesa. O manuscrito representa a versão mais completa da obra conhecida até hoje. 


\section{Capítulo I}

\section{Sobre o Pañcatantra}

\section{Estabelecendo relações - Pañcatantra e Kalīla e Dimna}

Ao contextualizar historicamente o livro de Kalīla e Dimna, é impossível ignorar a proximidade da obra indiana Pañcatantra, à qual pode ser relacionado em diversos aspectos. É preciso apontar as relações existentes entre as duas obras, relações que o fabulário árabe Kalīla e Dimna reconhece, visto que sua própria introdução (fictícia ou não) o apresenta como compilação dos conhecimentos adquiridos pelo médico persa Burzuwayh, enviado à Índia em busca de certo manual de decoro ${ }^{28}$ que punha animais de diversas espécies vivenciando situações passíveis de fornecer padrões de ética e conduta, i.e., o próprio Pañcatantra.

Sobre as semelhanças merece menção o seguinte passo, que se encontra na abertura do capítulo Propósito do livro, por 'Abdullah Ibn Almuqaffac ${ }^{29}$ : "Este é o livro de Kalīla e Dimna, composto pelos sábios da Índia a partir de paradigmas e histórias mediante os quais procuraram lograr a maior eloquência no discurso, na direção por eles pretendida”, que não apenas explicita a relação entre as obras mas trata do livro de Kalīla e Dimna como se fosse ele próprio o manual composto pelos sábios da Índia.

Lê-se, ainda, no encerramento do mesmo capítulo ${ }^{30}$ :

Quando verificamos que os persas traduziram este livro, passando-o da língua indiana para a persa, anexamos este capítulo em árabe a fim de que seja o alicerce mediante o qual se esclareça o que é este livro para quem o pretenda ler, compreender e citar. ${ }^{31}$

Tais passagens, se consideradas fidedignas, seriam suficientes para nos fazer crer que o livro de Kalīla e Dimna é uma tradução indireta ou versão do Pañcatantra e nada mais; no entanto convém, neste momento, problematizar a questão da autoria da tradução, originalmente

\footnotetext{
${ }^{28}$ Utilizaremos sistematicamente a palavra decoro para traduzir o termo árabe 'adab.

${ }^{29}$ Ibn Al-Muqaffac. Kalīla e Dimna. "Propósito do livro, por 'Abdullah Ibn Almuqaffac”, Tradução, organização, introdução e notas de Mamede Mustafa Jarouche. São Paulo, Martins Fontes, 2005. - (Biblioteca Martins Fontes). ${ }^{30}$ Segundo a edição consultada, há outro trecho divergente que encerra este capítulo, contudo, aí também se fala do caminho da tradução do livro, c.f.: "Disse 'Abdullah Ibn Almuqaffac: quando vi que os persas traduziram este livro do sânscrito ao persa e lhe anexaram um capítulo [...]”.

${ }^{31}$ Ibid., p. 13.
} 
- mas não unanimemente - atribuída a 'Abdullah Ibn AlMuqaffa ${ }^{c}$, um letrado de origem persa convertido ao islamismo.

Embora uma série de registros históricos atribua a composição da obra árabe a Ibn Almuqaffa ${ }^{c}$, possui esse personagem uma biografia envolta em incertezas, de dados tão pouco precisos quanto prováveis, chegando a ser, em alguns momentos, mais próximos da narrativa fantástica que da realidade. Por consequência, até mesmo a credibilidade de sua autoria tem sido frequentemente contestada; havia aqueles que a rejeitavam completamente e aqueles que a atribuíam não apenas a ele, mas a um grupo de escribas de que fazia parte. Houve, contudo, um erudito, 'Abū Rayhan Albiruni ${ }^{32}$ que, embora reforçasse a hipótese de o livro de Kalīla e Dimna ser uma tradução indireta do original indiano (cf: "Eu apreciaria muito poder traduzir o livro Pañcatantra, conhecido entre nós como Kalīla e Dimna, e que circulou entre o persa e o hindu [sic, por "sânscrito”], e a seguir entre o árabe e o persa [...]”), noutro passo colocava em dúvida a integridade da versão árabe, ao suspeitar que Ibn AlMuqaffa $^{c}$ teria alterado texto original, corrompendo-o:

[...] 'Abdullah Ibn AlMuqaffac', que nele [livro de Kalīla e Dimna] acrescentou o capítulo de Burzuwayh, objetivando gerar dúvida naqueles cuja fé religiosa é débil, e levá-los a propagar a doutrina maniqueísta. Sendo ele suspeito no que acrescentou, não deixaria de o ser no que traduziu. $^{33}$

Vale dizer que, a depender da edição que se utiliza, duas são as possibilidades para a autoria do capítulo referido por Albiruni ${ }^{34}$. Na tradução direta para o português, Mamede Jarouche adota a variante do texto árabe que dá o capítulo de Burzuwayh como parte do livro, mais especificamente seu ponto de partida, depois do prólogo de 'Abdullah Ibn AlMuqaffa'; nas outras edições de apoio, adota-se outra variante do texto em que o mesmo capítulo, nas palavras de 'Abdullah Ibn AlMuqaffac', é dado como uma inserção persa, como é possível observar no seguinte passo: “[...] quando vi que os persas traduziram este livro do sânscrito ao persa e lhe anexaram um capítulo, que é o do médico Burzuwayh [...]”. Dessa forma, temos três hipóteses de autoria para um único capítulo: 1. 'Abū Rayhan Albiruni o atribui a 'Abdullah Ibn AlMuqaffac $^{c}$, 2. um manuscrito o considera parte da obra e 3. outro mostra 'Abdullah Ibn AlMuqaffa ${ }^{c}$ responsabilizando os persas por sua inserção; dentre tais possibilidades, no entanto, não haveria como assinalar a mais segura.

\footnotetext{
32 ALBIRUNI, 1983 apud JAROUCHE, 2005.

${ }^{33}$ Ibid.

${ }^{34}$ Ibid.
} 
Assim sendo, com base nos breves apontamentos realizados, verifica-se que é possível elaborar mais suposições que certezas acerca da relação entre o livro de Kalīla e Dimna e o Pañcatantra. Embora muitas das evidências nos levem a crer que a obra em sânscrito seria uma espécie de matriz a partir da qual teria sido elaborada uma tradução pehlevi e que a partir desta, por sua vez, foi composta a tradução árabe, não é possível afirmar com segurança quem seja autor do texto árabe e, consequentemente, em que momento teriam sido inseridas determinadas passagens bastante dissonantes do "original” sânscrito. Os manuscritos árabes de Kalīla $e$ Dimna são muitos, e é impossível fazer uma edição crítica do texto, uma vez que as variantes são de tal modo que impediriam esse trabalho. Uma leitura e análise mais detalhada de ambas as versões, sânscrita e árabe, pode evidenciar traços muito peculiares de cada uma delas; observa-se no livro de Kalīla e Dimna uma série de diferenças, adaptações e acréscimos em relação ao seu precursor indiano, desde a alteração da estrutura narrativa passando pela mudança do desfecho de certas fábulas e até mesmo o acréscimo de um novo capítulo, que influencia todo o desenvolvimento de uma construção moralizante. Por conta de aspectos tais, não é possível, portanto, simplificar a questão da relação entre essas obras e solucioná-la nomeando a obra indiana como original e a árabe como cópia, ainda que seja necessário verificar a complexidade da relação extremamente próxima entre as duas obras.

Considerando o que foi dito até o momento sobre os dois fabulários, o presente trabalho doravante se dedicará a estabelecer, tanto quanto possível, os matizes dessa relação complexa, identificando e analisando os pontos em que as obras se aproximam e se afastam, a fim de corroborar ou descartar as hipóteses apresentadas.

\section{O Pañcatantra}

O Pañcatantra, (Cinco Tratados ou Cinco Princípios) é considerado precursor da fábula na tradição literária indiana e, como já mencionado, uma das bases do fabulário universal. Trata-se de uma compilação de textos realizada por volta do século I d.C. e posteriormente traduzida ao pehlevi, por volta do século VI d.C.. Não se atribui um autor à obra; de seu prólogo consta apenas que os “Cinco Tratados” foram elaborados por um sábio brâmane chamado Viṣnuç̧arman; nada impede, porém, considerar esse sábio (além de todo o fabulário e por que não dizer, o próprio prólogo?) um personagem criado e inserido na obra a fim de lhe conferir valor e legitimidade, hipótese que será retomada e analisada oportunamente. 
Os cinco livros que compõem o Pañcatantra chamam-se: A desunião de amigos (Mitrabheda), A aquisição de amigos (Mitra-samprāpti), A história dos corvos e das corujas (Kākolūkīya), A perda do bem conquistado (Labdha-praṇāśa) e A ação impensada (Aparīkṣita$k \bar{a} r a k a$ ). Independentes entre si, cada um deles apresenta uma linha condutora ou narrativaquadro na qual se inserem diversas outras histórias, ditados e provérbios, na maioria das vezes vivenciados por animais antropomorfizados e, vez ou outra, também por humanos. É possível observar que as fábulas que compõem os cinco livros da coleção são constituídas por narrativas fictícias nas quais exemplos práticos são apresentados e sustentados por razões teóricas que se baseiam em preceitos dos códigos de moral e ética da Índia Antiga, notavelmente o Código de Leis de Manu (Manavadharmaçãstra). Segundo estas características constitutivas, as fábulas indianas eram/são classificadas em manuais de literatura sânscrita ${ }^{35}$ como "tratados sobre a conduta” (nîtisâstra).

Os “Cinco Tratados”, a partir dessa relação com os preceitos morais indianos, teriam como funções principais apreender e ilustrar uma série de situações universais para as quais se propunham conduções mais adequadas, ou situações nas quais, por não se adotar os preceitos de conduta explicitados, a punição se daria por certa. É possível depreender do prólogo que acompanha o primeiro livro que, além dessa função principal, também havia um direcionamento original, ou um público específico: inicialmente destinado aos três filhos néscios do rei Amara-śakti, seriam os cinco tratados posteriormente ofertados a jovens que precisavam aprender, em pouco tempo e de forma concisa, as ciências políticas e morais, para que pudessem ter condições de governar corretamente e conduzir adequadamente as questões do reino.

Tais propósitos podem ser observados na seguinte passagem do prólogo do livro:

Desde então, o tratado de moral chamado Pañcatantra
circula pelo mundo com o
propósito de educação dos jovens. Por que
argumentar mais?
Quem estuda este tratado de moral e o conhece de
cor jamais é apanhado pela destruição, mesmo que esta seja
proveniente de Çakra

A partir desta passagem é possível observar que a obra atribui a si mesma funções de alta importância; foi encomendada a um sábio brâmane, trata de temas caros e de grande

${ }^{35}$ In.: ANÔNIMO. Pañcatantra: Fábulas Indianas - Livro I. Tradução de Maria da Graça Tesheimer; Maria Valíria Aderson de Mello Vargas; Marianne Erps Fleming. 2. Ed. São Paulo: Humanitas, 2004.

36 Ibid. 
interesse, está voltada a objetivos elevados, devendo, portanto, ser considerada de grande relevância, pois aqueles que a acessarem (segundo explicita o prólogo) poderão adquirir conhecimentos como os dos príncipes a quem ela primeiramente se endereçara. Vale apontar que entre o que o texto diz ser e o que ele de fato é, há uma grande distância que não pode ser ignorada, pois, aqui, novamente, é necessário que coloquemos em questão o quanto esse discurso não seria, assim como a introdução de um personagem sábio como elaborador dos Cinco Tratados, um artífice, submetido também a regras constitutivas do gênero.

\section{Sobre o prólogo e suas funções}

Além do que foi dito até o momento, cabem outros apontamentos especificamente acerca do prólogo do Pañcatantra antes de nos voltarmos para o conteúdo do livro; atrelado e antecedente à leitura do fabulário, é possível obter dele muito além dos brevemente apontados propósitos e destinatários da obra, como tentaremos explicitar a seguir.

O Pañcatantra, embora composto de cinco livros ou tratados, apresenta um único prólogo, que precede o primeiro livro. A abertura do prólogo - segundo a tradução utilizada neste trabalho ${ }^{37}$ - é realizada por meio de uma reverência aos "veneráveis Lakṣmĩ, Durgã e Ganeça! Glória aos grandes poetas!” e aos deuses do panteão indiano, conforme é possível observar a seguir:

Brahman, Rudra, Kumãra, Hari, Varuna e Yama, Vahni, Indra, Kubera, Candra e Ãditya, Saravastĩ, os oceanos, os yuga, as montanhas, Vãyu, a terra, as serpentes, os Siddha, os rios, os Açvin, Çrĩ, Diti e os filhos de Aditi, as mães divinas - Caṇḍikā e outras - os Veda, os lugares de peregrinação, os ritos sacrificiais, os Gaṇa, os Vasu, os grandes sábios e os planetas sejam sempre propícios! ${ }^{38}$

Essa reverência ou invocação aos deuses não está, no entanto, presente em todos os manuscritos da obra; consequentemente, os estudiosos não são unânimes em considerá-la parte da composição original ou interpolação.

\footnotetext{
${ }^{37}$ A tradução para o português utilizada como base para esta monografia se apoia em duas edições indianas, a saber: a de Çriçyãmãnacaranapãndeya (1975) e de M. R. Kãle (1912), Pañcatantra of Vsnuçarman, edição esta que constitui a principal fonte em sânscrito da obra.

${ }^{38}$ In.: ANÔNIMO. Pañcatantra: Fábulas Indianas - Livro I. Tradução de Maria da Graça Tesheimer; Maria Valíria Aderson de Mello Vargas; Marianne Erps Fleming. 2. Ed. São Paulo: Humanitas, 2004, p. 21.
} 
Seja como for, ao longo da leitura dos cinco livros alude-se a deidades em diversos pontos, já mesmo no encerramento do prólogo, que se refere à Çakra, epíteto de Indra, deus dos fenômenos atmosféricos.

Ainda que o fabulário não fizesse referência aos deuses, o personagem (fictício ou não) responsável pela elaboração dos cinco tratados, segundo o prólogo, é o brâmane Viṣnuçarman, “proficiente em todas as ciências”. O fato de ser caracterizado como brâmane confere teor religioso aos tratados, uma vez que os brâmanes são os representantes da casta sacerdotal, a primeira casta dos hindus, relacionados diretamente ao conhecimento provido por Brahman, criador do mundo e primeiro da tríade de deuses do Hinduísmo. Ainda que não seja possível falar do Hinduísmo nesse período da história, é inegável que o termo já se referia a um universo religioso indiano predecessor do que conhecemos hoje como Hinduísmo. Assim sendo, não é possível dissociar a composição do fabulário indiano dos diversos aspectos religiosos que o cercam.

Depois da reverência a todas essas divindades, lê-se uma homenagem a Manu, considerado o autor do código de leis que rege as condutas do fabulário, Vãcaspati, Çukra, autor de uma obra sobre política, Parãçara, autor de uma obra de jurisprudência e seu filho, possível compilador da epopeia Mahãbhãrata e, por último, a Cāṇakya, autor de outro tratado de política.

Só após as devidas reverências e homenagens seguidas da ressalva de que o próprio brâmane Viṣnuçarman teria percebido ser essa “a essência de toda a ciência política do mundo”, o propósito do livro passa a ser narrado. A partir da descrição da abertura do prólogo é possível afirmar que três temas ou áreas do conhecimento - Política, Religião e Letras - convivem e influenciam a obra com graus de importância, se não equivalentes, bastante próximos um dos outros. Considerando então a obra como um dos primeiros fabulários de que se tem notícia, permanecem as dúvidas - que serão retomadas mais adiante - acerca de como e em que medida tais temas estariam na base do gênero em questão: a Religião estaria de alguma forma presente na estrutura dos demais fabulários islâmicos ou seria apenas reflexo de um contexto de produção? Da mesma forma, como isso se dá com relação à Política e às Letras? E em que medida um fabulário poderia se aproximar mais de um tratado político ou de uma obra literária? É possível dissociar esses dois aspectos ao tratarmos da fábula enquanto gênero ou eles estariam intrinsicamente ligados? São questões que tornarão a ser retomadas ao longo do trabalho, mas, 
já na abertura do prólogo do Pañcatantra, encontramos alguns elementos que poderão fundamentar a análise dos problemas.

Depois da invocação/reverência aos deuses e a proeminentes figuras do conhecimento, o prólogo relata a história que "sempre se ouve" (2004), de um rei chamado Amaraçakti que, apesar de possuir um grande reino, as mais altas qualificações e conhecimentos, tinha três filhos muito ignorantes, fato que o preocupava e entristecia muito.

Para resolver essa questão, o rei convocou seus ministros e uma assembleia de quinhentos sábios, que se puseram a dialogar a fim de alcançar uma solução. Na discussão, dois novos problemas surgiram: a grande quantidade de conhecimentos que se precisava ensinar e de tempo exigido para apreendê-los, em contraposição ao curto prazo de que dispunham os jovens príncipes para adquiri-los.

Diante de tal contenda, sugeriu-se recorrer ao brâmane Viṣnuçarman, "proficiente em todas as ciências, famoso entre os estudantes” (2004) que, ao ser convocado, instruiu em seis meses os filhos do rei em todas as ciências necessárias. O método utilizado pelo brâmane para atingir tal proeza teria sido o manual por ele mesmo elaborado, o Pañcatantra, um tratado de moral com o “propósito de educação dos jovens” (2004).

O que se pode verificar a partir dessa narração é que a força motriz auto-atribuída, o motivo que leva à composição do fabulário, é a obtenção de conhecimento, conhecimento tido como muito importante, conforme se pode observar em passagens como "Dentre os filhos, um não nascido, um morto ou um estúpido, são preferíveis aqueles dois, o morto e o não-nascido, pois eles causam pequena dor; o tolo, por outro lado, pode atormentar durante toda a vida”39. O valor do conhecimento sobrepõe-se até mesmo às grandes riquezas, como se observa, e.g., em:

É preferível o aborto, é preferível abster-se de relações sexuais no período fértil, é preferível o natimorto e é preferível até que nasça mulher; é preferível a esposa estéril e é mesmo preferível que permaneça no útero, a ter um filho ignorante, mesmo dotado de bela aparência, riqueza e virtudes. ${ }^{40}$

Desta forma, é o conhecimento, segundo a narrativa do prólogo, o mais elevado bem a ser obtido, sem o qual de nada valem grandes somas de dinheiro ou mesmo outras virtudes. A

\footnotetext{
${ }^{39}$ ANÔNIMO. Pañcatantra: Fábulas Indianas - Livro I. Tradução de Maria da Graça Tesheimer; Maria Valíria Aderson de Mello Vargas; Marianne Erps Fleming. 2. Ed. São Paulo: Humanitas, 2004, p.23.

${ }^{40}$ Ibid.
} 
importância do saber é então laureada e, consequentemente, o valor do que será apresentado posteriormente, no fabulário, torna-se ainda mais inestimável, já que se trata, ele próprio, de um manual sobre conhecimentos de moral e ciências.

Neste ponto é válido ressaltar o fato de que já o prólogo da obra é apresentado em forma de narrativa, narrativa esta que, embora possa ser composta de elementos reais, se aproxima muito mais das características ficcionais que permeiam todo o manual. Assim sendo, não é possível afirmar que o personagem Viṣnuçarman, a quem se atribui no prólogo a composição do manual, seja o responsável empírico por essa intenção, podendo ser apenas um personagem devidamente elaborado com determinadas características para conferir um caráter de importância e sabedoria à obra.

Ainda é possível perceber no prólogo a existência do mesmo recurso utilizado nos cinco tratados, a inserção de máximas, como na passagem “A ciência das palavras é deveras infinita, enquanto a vida é diminuta e os obstáculos são numerosos; portanto, a essência deve ser recolhida, rejeitando-se o inaproveitável, do mesmo modo que o cisne recolhe o leite do oceano” (2004). Esta máxima é apresentada por meio das palavras de um ministro, tal como se dará ao longo de todo o fabulário, em que a ocorrência das máximas se dá sempre na relação entre um sujeito que detém determinado conhecimento e o transmite para outro, tendo, assim, função didática, observável já neste momento que antecede a narrativa propriamente dita.

Pode-se dizer, portanto, que prólogo já contém as mesmas estratégias discursivas utilizadas no fabulário, o que relativiza seu conteúdo: até que ponto a narrativa elaborada não seria, ao invés do relato de uma verdade, a produção de um efeito de verossimilhança ${ }^{41}$ ? Ao se ler que um rei põe o conhecimento acima de toda sua riqueza e da extensão de seu reino, e confere a um sábio respeitado e reconhecido a tarefa de elaborar um manual com "a essência de toda ciência política do mundo” - que, com efeito, e de forma bem-sucedida, é a obra em questão -, quem colocaria em dúvida a importância de seu conteúdo e, mais além, quem não almejaria acessar tal obra? Claramente estamos, aqui, tratando do leitor como figura ideal, construída pela obra por meio das injunções que apresenta, ou seja, leitor que interage com a

\footnotetext{
${ }^{41}$ Considerando os conceitos clássicos de verossimilhança, talvez eles não pudessem ser aplicados à fábula, posto que, segundo Aristóteles uma de suas características principais é o fato que de ela é fictícia, mentirosa. Contudo, nos referimos a um "efeito de verossimilhança” justamente para aludir à artificialidade do conceito, a fábula não é verdade, por mais que se preencha de estratégias nesse sentido.
} 
obra tal como mais um personagem construído por ela, em uma imagem refletida do discurso de convencimento ${ }^{42}$.

Como se pôde observar, o prólogo do Pañcatantra se apresenta na forma de uma narrativa, de aspecto ficcional, que se propõe a dar uma justificativa anterior à composição do fabulário, uma razão de ser para ele. Dessa forma, ao longo do prólogo obtém-se então o objeto (a educação dos jovens), a forma (um compêndio conciso) e a conexão entre a forma e o objeto resultante do curto espaço de tempo para o aprendizado. É interessante apontar que em muitas tradições é recurso discursivo importante falar da brevidade do livro ${ }^{43}$. A concisão da forma é uma redução do tempo (consistindo, assim, em um ganho de tempo), podendo ser esse mais um recurso retórico para falar do valor da obra.

Vale expor ainda que o prólogo não se propõe a realizar uma análise da obra nem a dizer quais artifícios serão utilizados na elaboração dos tratados. Não há menção às fábulas, ao formato de narrativa que será (e já é) utilizado, muito menos a uma chave de leitura que deva ser adotada; não há direcionamento. O brâmane-personagem-autor do manual só se encarrega de dizer que "Quem estuda sempre este tratado de moral e o conhece de cor jamais é apanhado pela destruição, mesmo que esta seja proveniente de Çakra” (2004). Esta observação, aparentemente desnecessária, se fará relevante quando contrapusermos os prólogos de Pañcatantra e Kalīla e Dimna, o que será feito adiante.

\section{A narrativa-quadro ou prólogo-moldura}

Esgotadas por ora as observações acerca do prólogo do fabulário indiano, passemos agora a uma breve apresentação e discussão de outra característica que o Pañcatantra e o Kalīla e Dimna têm em comum, a narrativa-quadro ou prólogo-moldura, ou, como ainda é possível dizer, a narrativa circular ou estrutura-em-cadeia. Todos esses termos se referem a um procedimento narrativo que salta aos olhos nos dois fabulários e que consiste no fato de que, a partir de uma narrativa principal, vão se desenvolvendo outros níveis de narrativa (ou

\footnotetext{
${ }^{42}$ Iser insiste naquilo que ele chama de repertório, isto é, o conjunto de normas sociais, históricas, culturais trazidas pelo leitor como bagagem necessária à leitura. Mas também o texto apela para um repertório, põe em jogo um conjunto de normas. Para que a leitura se realize, um mínimo de interseção entre o repertório do leitor real e o repertório do texto, isto é, o leitor implícito, é indispensável. As convenções que constituem o repertório são reorganizadas pelo texto, que desfamiliariza e reforma os pressupostos do leitor sobre a realidade. (COMPAGNON, 2006, p. 152- 153).

${ }^{43}$ Aqui podemos lembrar da clássica, por exemplo.
} 
subnarrativas), outras fábulas vão sendo contadas, tanto pelos personagens da narrativa-quadro como por outros personagens, inseridos nas fábulas contadas por eles. Assim, uma narrativaquadro pode conter, por exemplo, dois animais que conversam entre si e um deles, para convencer ou demover o outro de algo, lhe contará uma fábula em que dois outros animais podem estar conversando entre si e um deles pode contar uma fábula para o outro, e assim por diante, até que as fábulas cheguem, cada uma delas, ao seu encerramento moralizante, retornando nível por nível até chegar à narrativa-quadro ou prólogo-moldura. Isso confere um caráter circular e intertextual à narração, pois “cada fábula passa a ser um intertexto de outra que é também intertexto de outra e assim por diante” (TESHEINER; FLEMING; VARGAS, 2004, p.12).

Tal procedimento de uma narrativa que contém subnarrativas que também contêm subnarrativas pode ser observado em outros fabulários e contos indianos e árabes, sendo $O$ Livro das Mil e Uma Noites um exemplo de sua aplicação bem-sucedida: ao contar a cada noite uma estória que é intercalada por outra e por outra seguidamente até que, ao raiar do dia, uma delas seja suspensa (deixando, por consequência, todas as outras sem encerramento), Šahrāzād mantém suspensa também a curiosidade do rei Šāhriyār e com isso ganha mais uma noite, usando seguidamente seu artifício e escapando de sua sentença de morte noite após noite, até conseguir mudá-la. O efeito alcançado por Šahrāzād sobre o rei Šāhriyār pode ser usado aqui como justificativa para tal procedimento narrativo: manter, de forma deleitosa e fluente, a atenção e a curiosidade do leitor; antes que uma fábula se encerre já existe uma outra em desenvolvimento e outras a ser iniciadas, e assim sucessivamente.

No Pañcatantra, conforme foi dito anteriormente, há cinco livros ou tratados, independentes entre si, e em todos eles é possível observar a utilização desse recurso, porém, de diferentes formas. Podemos ilustrar cada uma delas da seguinte maneira: 


\section{Diagrama do Livro I}

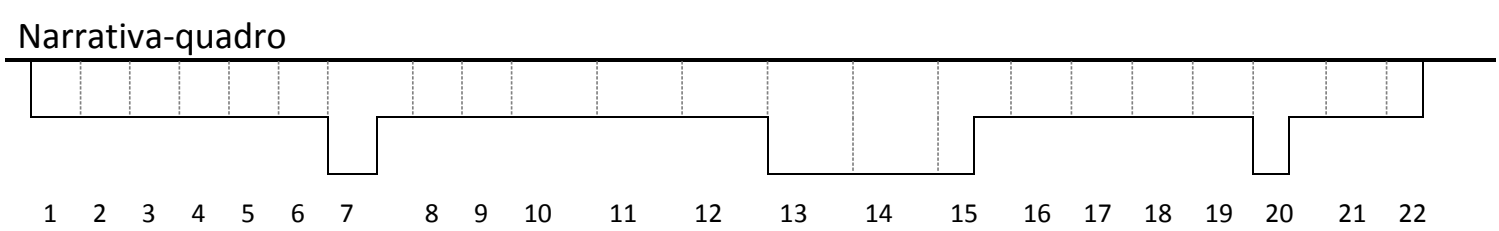

Figura 1

Há uma narrativa-quadro no livro intitulado como “A desunião de amigos” que pode ser resumida pela seguinte estrofe de abertura "A grande amizade que crescia entre um leão e um touro, na floresta, foi completamente destruída por um chacal maledicente e muito ambicioso" (2004) e, ao longo de seu desenvolvimento, vinte e duas fábulas são contadas, em camadas diferenciadas. É possível dizer que, além da narrativa-quadro, há outros dois níveis da narrativa, conforme foi ilustrado na figura 1. Isso significa que dentro da narrativa principal há narrativas contadas que abarcam outras narrativas, como podemos verificar no trecho entre as fábulas seis e sete. A partir de uma fábula (seis) contada por Damanaka para Karațaka, dois dos personagens principais da narrativa-quadro, surge um novo personagem, um chacal, que irá contar a um casal de corvos uma nova fábula (sete). Quando esta nova fábula é contada, as duas narrativas anteriores entram em suspensão e só voltam a se desenvolver quando ela alcança seu objetivo moralizante. Assim que este objetivo é alcançado, verificamos que o nível narrativo em que estava inserida a fábula seis pode voltar a se desenvolver, chegando, por conseguinte, à fábula oito. Podemos observar na figura 1 que esse procedimento será utilizado em outros dois momentos até que, ao final da fábula vinte e dois, se encerre também mais um nível narrativo e, por fim, a narrativa-quadro. 


\section{Diagrama do Livro II}

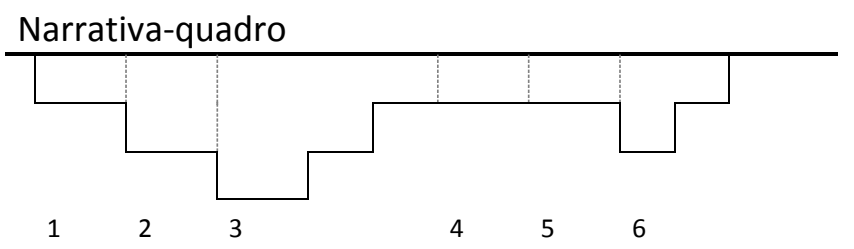

Figura 2

No segundo livro, “A aquisição de amigos”, a narrativa-quadro pode ser resumida pela estrofe "Mesmo desprovidos de riquezas, os sábios versados nos Veda alcançam facilmente seus objetivos, como sucedeu com o corvo, o rato, a gazela e a tartaruga” (2008) e abarca mais seis fábulas que, por sua vez, se desenvolvem em três níveis além do emoldural. Isso significa que, além dos níveis desenvolvidos no primeiro livro, há neste um novo, que mantém a mesma condição de desenvolvimento dos demais. Assim, novamente será possível perceber na leitura que, quando uma nova fábula é iniciada, as demais são suspensas e cada nível só retoma seu desenvolvimento quando o anterior é encerrado.

\section{Diagrama do Livro III}

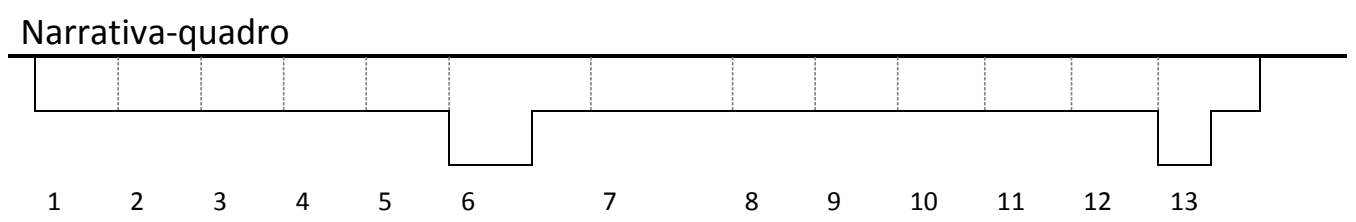

Figura 3

O terceiro livro, “A história dos corvos e das corujas”, traz a seguinte estrofe-resumo como narrativa-emoldural: "Ninguém deve confiar em um ex-oponente ou em um inimigo que se tornou amistoso: olha a caverna, cheia de corujas, consumida pelo fogo ateado pelos corvos”. Assim como nos livros anteriores, este também tem narrativas que se desenvolvem em outros 
níveis - dois, a saber - e que suspendem a narrativa principal. O mesmo método apresentado até então é observado de uma maneira mais simplificada, e poucas vezes se recorre a outras camadas. Conforme é possível observar na figura 3, o segundo nível da narrativa será utilizado em dois momentos (nas fábulas seis e treze) até que, ao final da fábula treze, se encerre também mais um nível narrativo e, por fim, a narrativa-quadro. Esse livro, especificamente, em diversas passagens retiradas do tratado de política indiano chamado Kãmandakĩyanĩtisãra, escrito por Kãmandaki ${ }^{44}$, aproximando então a fábula tanto dos manuais de conduta como dos tratados de política, desde épocas bastante longínquas.

\section{Diagrama do Livro IV}

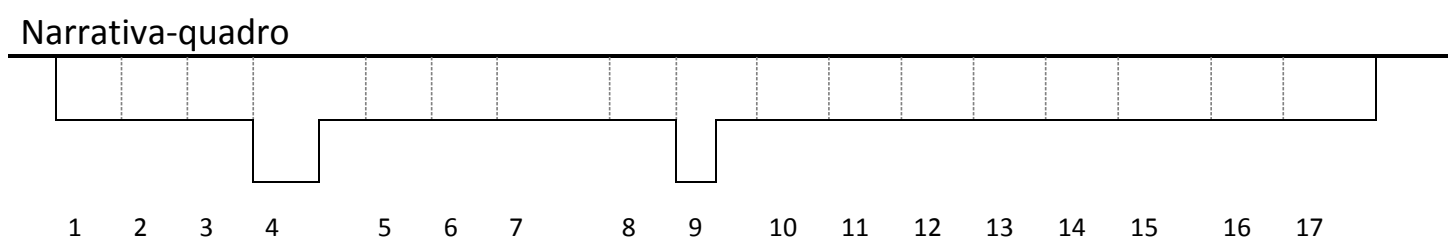

Figura 4

Em “A perda do bem conquistado”, a narrativa-quadro é resumida pela seguinte estrofe: “Aquele que conserva a presença de espírito quando surgem imprevistos supera as dificuldades, como fez o macaco que estava no meio da água”. Novamente se apresenta o mesmo modo de elaboração que constitui todos os outros livros: a narrativa quadro nos é brevemente apresentada e em seguida os personagens passam a interagir entre si de tal modo, e, com os objetivos previamente apresentados, contam uns aos outros fábulas que, em certos momentos, propiciam outros níveis narrativos à leitura. Tal como nos livros I e III, este também apresenta, além da narrativa principal, dois outros níveis que se intercalam e se desenvolvem. Não há, como foi possível observar no Livro II, a interposição de muitos níveis na narrativa e mesmo quando se utiliza do segundo nível é em pouca proporção e pontualmente, apenas nas fábulas quatro e nove, que rapidamente se encerram e, assim, retornam ao primeiro nível da narrativa. Ao

\footnotetext{
${ }^{44}$ ANÔNIMO. Pañcatantra: Fábulas Indianas - Livro II e III. Tradução de Maria da Graça Tesheimer; Maria Valíria Aderson de Mello Vargas; Marianne Erps Fleming. 2. Ed. São Paulo: Humanitas, 2004, p. 12.
} 
término da fábula dezessete, o primeiro nível se encerra e rapidamente se dá o fechamento da narrativa-quadro.

\section{Diagrama do Livro V}

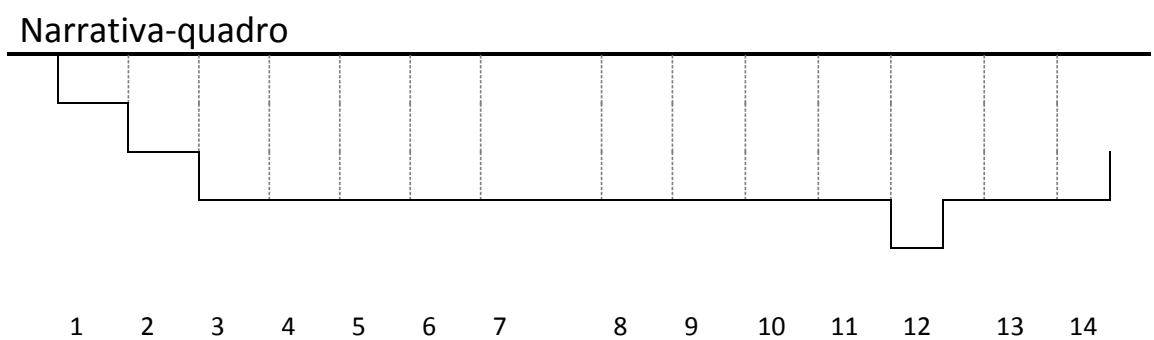

Figura 5

O quinto livro ou “A ação impensada” destoa dos anteriores porque, embora, tal como os outros quatro, mantenha o procedimento de estrutura-em-cadeia, não faz, em seu encerramento, a amarração que dá o caráter circular ao fabulário. Há uma narrativa-quadro, explicitada na estrofe "O homem não deve fazer o que o barbeiro fez - algo visto de modo indistinto, pouco compreendido, mal ouvido e mal examinado", e o desenvolvimento de outros quatro níveis, mas apenas dois são devidamente finalizados. A partir da narrativa-quadro passa a se desenvolver o primeiro nível, em que magistrados contam a um personagem a fábula " $\mathrm{O}$ brâmane Devaçarman” e, no desenvolvimento desta fábula, uma brâmani passa a contar uma fábula ao personagem-título, dando início a um outro nível narrativo, com a fábula dois, “História do homem portador de uma roda na cabeça”. A partir deste nível narrativo ainda outro é iniciado na fala do brâmane que encontrara ouro, o qual começa a contar a fábula três, "Os brâmanes estúpidos que ressuscitaram um leão”. O terceiro nível narrativo se desenvolve até a fábula doze, em que o quarto nível passa a ser desenvolvido e logo é encerrado, para que em seguida se retome o anterior. Ao chegarmos à fábula quatorze, percebemos que ela dá um encerramento ao terceiro nível, mas não retoma os anteriores, ou seja, sabemos como se encerra o nível narrativo que tem início na fábula dois e que abrange a situação de uma conversa entre o brâmane que portava a roda na cabeça e o brâmane que encontrara ouro, mas não sabemos como se encerram os níveis anteriores. Poder-se-ia dizer que a tradução do quinto livro, por 
conta deste encerramento, denunciava, na verdade, uma incompletude, e que a obra original traria consigo um encerramento tal como os observados nos livros anteriores, porém, ao término do quinto livro há uma conclusão que, além de dar conta dele, conclui também os demais livros em uma unidade, como se pode observar:

Depois de ouvir essa última história, o brâmane que encontrara ouro, tendo recebido a permissão do brâmane que portava a roda, partiu de volta para a sua casa.

Conclui-se, assim, o quinto livro do Pañcatantra, intitulado “A ação impensada”, composto pelo venerável Viṣnuçarman.

Conclui-se também o tratado de moral intitulado Pañcatantra. ${ }^{45}$

Poderíamos sugerir ainda que esta conclusão, por ser excessivamente abrupta, seria posterior à obra original, o que nos parece bastante adequado, tendo em vista a forma como se desenvolveram todos os livros anteriores e as suas narrativas.

\section{Os personagens}

O Pañcatantra é povoado por uma série de animais muito diversos como personagens antropomorfizados, e também por humanos. A princípio, isso poderia provocar no leitor menos iniciado nos fabulários o seguinte questionamento: "Mas não deviam ser apenas animais que agem como humanos os personagens das fábulas?” De fato, ao procurarmos por definições acerca do gênero literário, muitas serão as vezes em que nos depararemos com referências às fábulas como obras em que animais se comportam como humanos em situações moralizantes, tal como é possível observar em:

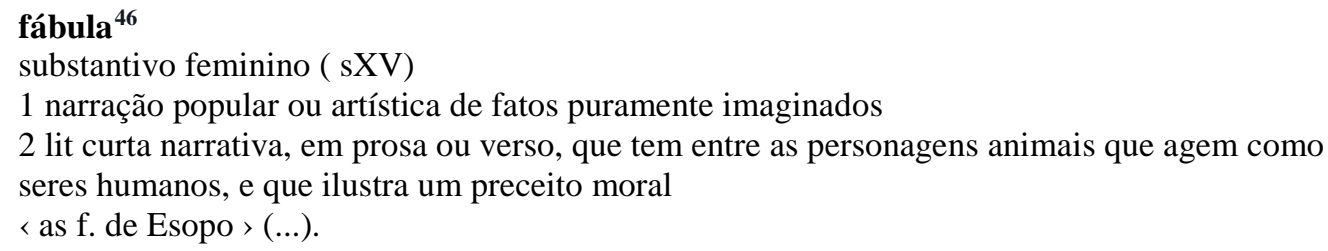

Se formos mesmo observar ao longo da tradição, entre aqueles que se dedicaram ao gênero e seus fabulários, é possível verificar que os personagens que povoam os fabulários são majoritariamente animais, em pouca medida objetos inanimados e em menor ainda, humanos, homens e mulheres. Contudo, cá estão eles presentes, tanto no fabulário Pañcatantra como no

\footnotetext{
${ }^{45}$ ANÔNIMO. Pañcatantra: Fábulas Indianas - Livro IV e V. Tradução de Maria da Graça Tesheimer; Maria Valíria Aderson de Mello Vargas; Marianne Erps Fleming. 2. Ed. São Paulo: Humanitas, 2004, p. 228.

${ }^{46}$ HOUAISS, Antonio; VILLAR, Mauro Salles. Dicionário Houaiss da Língua Portuguesa. Rio de Janeiro: Objetiva, 2009.
} 
Kalīla e Dimna, podendo se pensar também em fabulários ocidentais e cristãos, como o Livro das bestas ${ }^{47}$, de Raimundo Lúlio (século XIII) e, neste trabalho, ao nos propormos a apresentar hipóteses para as construções e funções dos personagens das fábulas, nos deparamos também com a necessidade de explicar: por quê, em determinadas fábulas e contextos, são utilizados humanos e não animais?

Não sendo este o tema principal do presente trabalho, nos deteremos em apresentar hipóteses apenas ao uso de personagens humanos quando eles estiverem presentes em fábulas aqui trabalhadas, e seguindo os propósitos previamente delineados, ou seja, embora haja uma série de personagens humanos (tanto homens como mulheres) povoando os dois fabulários mencionados, neste trabalho focaremos apenas naqueles que ocupam lugares que poderiam, em princípio, sem uma análise mais adequada, ser ocupados por aqueles personagens animais que interagem nas posições e relações de poder-saber.

O primeiro livro do Pañcatantra e os dois primeiros capítulos de Kalīla e Dimna tratam de um tema em comum, num pano de fundo político, que envolve as vicissitudes das relações entre o poder e o saber. Esse tema será revisitado nos outros dois livros estudados neste mestrado, O livro do tigre e do raposo e O leão e o chacal mergulhador, em releituras que trazem tanto outras possibilidades de interpretação como outros contextos, que, conforme se observará adiante, interferem na construção dos personagens e na condução das narrativas. Independentemente das peculiaridades de cada texto, personagens alegóricos sempre representarão - ainda que de formas diferentes - aspectos da relação já mencionada, podersaber. A seguir, passaremos a analisar os personagens que encabeçam essa ligação aparentemente antagônica e como cada um desses pólos se constrói.

\section{Poder - Leão}

Logo na narrativa-quadro do primeiro livro do Pañcatantra, “A desunião de amigos”, nos deparamos com este personagem e com a sua importância para a fábula, que pode ser verificada inclusive em seu preâmbulo, com o adágio que anuncia: “A grande amizade que crescia entre um leão e um touro na floresta foi completamente destruída por um chacal

\footnotetext{
${ }^{47}$ Segundo Steve Jaulent, o Livro das bestas se inspira fortemente nos fabulários árabes e, em menor medida, nos fabulários franceses para, por meio de animais antropomorfizados, fazer uma crítica à sociedade humana. Nele, novamente o leão ocupa o lugar de soberano, e as temáticas se aproximam das dos espelhos de príncipes.
} 
maledicente e muito ambicioso”. De fato, ao longo da leitura é possível averiguar que por meio desse fio narrativo é que se desenvolverão não apenas uma série de fábulas que servirão de intertextos entre si e para a narrativa-quadro, mas também a recorrência do leão, reforçando a sua importância enquanto personagem-tipo. Além do personagem leão que abre a narrativaquadro, Piñgalaka, há ainda mais quatro fábulas no Livro I em que a presença desse personagem-tipo - e sua importância - é verificada. Adiante, iniciar-se-á a análise dessas ocorrências.

Piñgalaka, em Livro I, narrativa-quadro - “A desunião de amigos”: Inicialmente atemorizado pelo som ao longe de um animal que não identifica, mas que imagina ser tão forte como sua possante voz, não diz nada aos seus servos sobre seu medo para não demonstrar fraqueza, mas dois chacais o percebem. É convencido pelo chacal Damanaka a deixá-lo aproximar-se do animal em nome do rei, e é informado que aquele animal é Samjĩvaka, um touro que ali estava por ter se ferido e, por conta disso, fora deixado para trás pelos homens. Ao descobrir que o possuidor da voz que o aterrorizava era uma criatura comedora de ervas, o leão não apenas se acalma como também convida o touro a fazer parte de seu séquito e dele se aproxima. Na aproximação e estabelecimento de uma amizade com o touro, há uma passagem que se refere a esta relação como transformadora do “simplório Piñgalaka num sábio”. Por entabular uma amizade tão próxima com o touro, o leão acaba afastado e desinteressado de seus servos que, por sua vez, passam a abandoná-lo tomados pela fome. Diz-se que o touro afasta-o da lei da selva, integrando-o aos costumes da cidade. Por conta de tudo isso, Damanaka, o chacal, elabora um ardil para encerrar a amizade do leão e o touro e acaba por provocar a morte do touro pelas garras do próprio Piñgalaka.

Bhãsuraka, em Livro I, fábula VIII - “O leão Bhãsuraka”: o personagem é descrito como detentor de um vigor tal que provocava a morte de "muitas gazelas, lebres e outros animais” e, por conta disso, os animais se mobilizam para saciar a sua fome e manter a sobrevivência da maioria. É tratado pelos animais como soberano, embora na narrativa, em certos momentos, haja referências a sua estupidez. Representa um poder enfurecido, raivoso, porém desprovido de saber ou de figuras dele detentoras ao seu redor. Por conta disso, é facilmente enganado por uma lebre.

Leão, em Livro I, fábula X - “O chacal Caṇụarava”: o leão e os demais habitantes de uma floresta são momentaneamente enganados pelo chacal que dá nome à fábula e que estava irreconhecível por ter sido banhado em tinta azul-índigo. Tomado como uma deidade, o chacal 
domina todos os animais e lhes distribui cargos, sendo que o leão recebe o de ministro, ou seja, o segundo após o chacal. Descoberto ao uivar para a lua, o chacal é morto e feito em pedaços “pelo leão e os outros”.

Madotkața, em Livro I, fábula XI - “O leão Madotkața”: personagem que tinha como “serventes, entre outros, um tigre, um corvo e um chacal” recebe um camelo perdido de sua caravana e lhe oferece segurança. Não podendo ser contrariado, por sua força e soberania, sofre um ardil dos mencionados servos, encabeçado pelo chacal, e é convencido a permitir que o camelo dê sua vida em salvação dos demais.

Vajradamișțra, em Livro I, fábula XVI - “O leão Vajradam̦șțra”: novamente o leão que dá título à fábula tem entre seus servos um chacal que promove um ardil para que um pequeno filhote de camelo que havia crescido ao lado do leão e se afeiçoado a ele seja morto com a permissão de Vajradamișțra.

Graças a este levantamento, é possível observar algumas recorrências na construção do personagem-tipo leão no Livro I do Pañcatantra: detentor de força e poder em todas as fábulas, ocupa invariavelmente a posição de soberano diante dos outros animais, que se organizam ao redor dele para obter proteção, alimentação e sobrevivência - sendo que alguns dos animais também almejam privilégios outros, de natureza política. Em todas as fábulas o leão é descrito como consciente de sua posição hierárquica e de seu poder e, em decorrência disso, pode tanto revelar características protetoras - como em relação ao touro Samjĩvaka ou aos camelos das fábulas XI e XVI -, como autoritarismo e tirania - tal como narrado na fábula VIII.

Curiosamente, apesar de seu poder e força, o personagem-tipo leão é enganado, vítima de ardis, em todas as cinco fábulas em que é utilizado. É possível dizer, aliás, que as fábulas VIII, X, XI, XVI são, em certa medida, pequenas repetições e antecipações do que acontecerá ao leão Piñgalaka ao término da narrativa-quadro: ele será vitimado por um estratagema. O poder se mostra, a partir dessa elaboração, como vulnerável e sujeito a manipulações, independentemente de seu tamanho e abrangência.

Aqui é interessante observar que, excetuando a fábula VIII, em que o personagem-tipo leão é descrito apenas em seus aspectos mais negativos, quase como um perigo aos seus servos (com características não de realeza, mas de tirania), em nenhuma outra das fábulas em que o leão aparece seu poder é questionado ou o ardil elaborado contra ele almeja eliminá-lo; de 
alguma forma, a posição ocupada pelo leão é validada pelos outros personagens que, mesmo capazes de ludibriá-los, não atentam diretamente contra ele nem desejam para si o papel de soberanos. Novamente, podemos elaborar, a partir desses dados, inferências sobre o poder que é delineado no fabulário: é mais comum o desejo pela proximidade do poder e a possibilidade de manipulá-lo em direção ao alcance de seus propósitos do que o desejo pelo poder em si. Todos os personagens que elaboram estratagemas contra o leão pretendem, com isso, algum favorecimento pessoal, mantendo, contudo, o rei em seu lugar (talvez até mesmo para que ele permaneça manipulável). Mesmo a lebre da oitava fábula, após aniquilar o leão tirano que oferecia risco a ela e aos demais animais da floresta, mantém seu papel, sem se alçar à posição antes ocupada por Bhãsuraka. Ainda seria possível relativizar esta hipótese após a leitura da fábula X, “O chacal Cạ̣ḍarava”, mas, embora nesta fábula o chacal detenha momentaneamente o poder e chegue até mesmo a ser conclamado como rei pelos outros animais, em sua breve soberania elege o leão como ministro - cargo mais próximo do rei e que é costumeiramente ocupado por personagens considerados sábios, característica que não aparece em nenhum momento como atribuída ao leão -, ou seja, o mantém próximo de si e com elevada função, reconhecendo assim a sua importância. É interessante observar que, entre todos os ardis elaborados em relação ao personagem-tipo leão, este, especificamente, falha: o chacal é desmascarado, não tem condições de manter o poder (inclusive por sua natureza/instinto - pois é devido justamente a ele que seu plano falha) e, por consequência, é “morto e feito em pedaços pelo leão e os outros”48. Talvez esta seja mais uma ilustração em favor de nossa hipótese de que é mais atraente e acertado aos animais manter o leão no poder mesmo que - e sobretudo manipulado, a tomar o seu lugar.

Fica ainda uma questão a respeito deste personagem-tipo e sua caracterização do poder: aquele que detém o poder deve, inclusive, não ser sábio? Não ter acesso ao saber se não o que vem direcionado de certos membros de seu séquito e, consequentemente, estar sujeito a manipulações e trapaças? As questões apresentadas são consideradas importantes principalmente com base na leitura da narrativa-quadro: quando Piñgalaka passa a ter acesso ao saber, por intermédio de sua relação com o touro Samjjĩvaka, e assim se distancia de seus afazeres - afazeres estes que mantêm o equilíbrio e a subsistência de todos os animais ao seu redor -, passa a representar um problema: o seu distanciamento da "lei da selva” é um risco para toda a floresta e, por isso, Damanaka elabora um ardil para afastar leão e touro. O

\footnotetext{
${ }^{48}$ ANÔNIMO. Pañcatantra: Fábulas Indianas - Livro I. Tradução de Maria da Graça Tesheimer; Maria Valíria Aderson de Mello Vargas; Marianne Erps Fleming. 2. Ed. São Paulo: Humanitas, 2004, p.147.
} 
personagem-tipo leão, então, precisa ser, como dito na própria narrativa, "simplório”? Uma observação que pode ser acrescentada a essas já mencionadas reside no fato de que, em momento algum, nenhum dos leões presentes nas fábulas conta uma fábula, eles são sempre e apenas ouvintes de outros animais, que lhes trazem as narrativas com os mais variados propósitos (alguns deles já descritos aqui). O leão não transmite saber, ele apenas recebe saber, sendo pouco possível observar inclusive se ele chega a apreender de fato esse saber - e a aplicálo a outras situações - ou se se utiliza dele apenas pontualmente, convencido pelos outros ao seu redor. Ao término de uma análise mais aprofundada, que envolva os outros fabulários, talvez seja possível verificar qual a resposta para essas dúvidas.

Vale apontar, no entanto e novamente, a importância desse personagem-tipo, que ocupa, na maioria das vezes, o papel-título da fábula e, se não a nomeia, figura entre os personagens principais dela, na maioria das vezes como motivador de ações.

Antes de nos dedicarmos aos próximos personagens, ainda é possível e necessário nos voltarmos para certos aspectos dessa composição de personagem-tipo. Adiante, trataremos de verificar a ocorrência do personagem-tipo leão e também a ocorrência de outros tipos de personagens que, em determinados momentos, ocupam a posição de poder associada ao reinado: há, ao longo dos cinco livros, tanto outros leões como homens que ocupam essa posição, além de outras espécies de animais. Vamos então estudá-los para que adiante seja possível dizer em que medida diferem ou se aproximam do personagem-tipo leão.

Além das cinco fábulas em que o personagem-tipo aparece no Livro I, ao longo dos outros quatro livros ainda há seis outras vezes em que podemos verificar um leão em ação. Embora elas não tenham, como as cinco fábulas já mencionadas, caráter mais político, em todas elas ainda há pontos recorrentes iguais aos que já foram previamente tratados: o leão continua a ser uma alegoria de poder, temido por todos, homens e animais a seu redor e detentor de muita força, sendo, em várias situações, mencionado como rei. Outra recorrência ocorre em duas fábulas em que é enganado por um chacal, tal como em situações anteriores. Os leões que ilustram as fábulas dos outros livros já não são personagens-chave para todas as fábulas, mas ainda nomeiam algumas delas e continuam a servir como elementos motivadores para ações. O leão, mesmo quando tem uma participação pequena na fábula, é um personagem determinante. 


\section{Poder - Outros personagens}

Não é apenas o leão quem ocupa a posição de rei ou detentor do poder nas fábulas do compêndio Pañcatantra. No decorrer da leitura desta obra, somos apresentados a outros animais caracterizados dessa forma e, como dito anteriormente, há fábulas em que humanos (exclusivamente homens) são representados como reis. De acordo com os propósitos inicialmente estabelecidos para este trabalho, nos cabe agora analisar quais são esses personagens e se o poder se manifesta por meio deles da mesma forma que foi possível observar no personagem-tipo leão.

Humano - É o personagem que mais aparece representado como rei no decorrer dos cinco livros; detentor da soberania, suas ocorrências neste papel chegam até mesmo a superar as do leão: enquanto os humanos são representados em treze fábulas como rei, o leão aparece em onze. Contudo, é necessário que se leve em conta o fato de que humanos são representados diversas vezes, em diversos papéis (rei, brâmane - não necessariamente sábio ${ }^{49}$-, ladrão etc.); já leões são representados apenas onze vezes, mas em todas elas são reis. Enquanto ao humano cabe uma série de papéis, para o leão só existe uma possibilidade, ele só pode ser representação/alegoria do poder. Até mesmo quando o leão é acompanhado por apenas um personagem $^{50}$ ou anda só ${ }^{51}$, ainda assim é tratado como soberano, como se de fato essa soberania fosse sua condição inerente. Além disso, vale apontar também que mesmo os reis representados por humanos não são utilizados para atuar em fábulas que tenham como pano de fundo situações em que a política e seus trâmites são desenhados: quando um rei humano é utilizado em uma fábula, ela invariavelmente o emprega como coadjuvante, apenas para ilustrar situações cotidianas; a posição ocupada, embora traga consigo, necessariamente, poder, não é a mesma do leão e, consequentemente, o modo como esse poder é delineado também difere: talvez os jogos políticos não pudessem ser, nem mesmo em uma fábula, representados por homens.

Corvo, Coruja, Elefante, Rã e Rato - Também representados em algumas fábulas como reis, esses personagens têm, no entanto, pouquíssimas ocorrências nesse papel, o que dificulta a análise e comparação. Com exceção da rã, que é utilizada em duas fábulas como

\footnotetext{
49 As fábulas “Os brâmanes estúpidos que ressuscitaram um leão” - Livros IV e V, p. 157 e “Os eruditos mentecaptos” - Ibid, p. 163 contém exemplos de brâmanes não sábios.

${ }^{50}$ A fábula "A história de Karalakesara” - Ibid, p. 39 trata de um leão que tem como único acompanhante um chacal de nome Dhusaraka

${ }^{51}$ A fábula “O chacal chamado Mahacaturaka” - Ibid, p. 123 tem como personagem um leão sem séquito.
} 
soberana, todos os outros elencados são ilustrados como reis uma única vez cada no Pañcatantra. O que se pode observar em princípio é que esses animais são representados como reis apenas de suas respectivas espécies, ao contrário do leão, que ocupa o cargo mais alto da hierarquia entre todas as variedades de animais. Não há ocorrência em nenhuma fábula, mas é possível supor, com base na leitura de todo o compêndio que, caso esses reis estivessem na presença de um leão, ainda assim se subordinariam a ele, de modo que o poder do leão é apresentado como absoluto, enquanto o dos demais animais é relativo, limitado. O rei corvo e a coruja são os que atuam em uma fábula ${ }^{52}$ de maior caracterização política, que ilustra justamente a disputa entre duas diferentes espécies de animais. Talvez seja possível apontar que tal fábula não pudesse existir caso mudássemos os personagens: não haveria como um bando de leões travar batalha com qualquer outro bando, de qualquer outra espécie, justamente pelo fato de que todas elas seriam submissas aos leões. Podíamos supor que um bando de tigres pudesse ocupar um lugar em tal contenda, contudo, em mais de uma fábula é possível verificar que mesmo os tigres são submissos aos leões. Destarte, entendemos que os reis representados por essa fábula são outros animais por se tratar de uma contenda entre dois reinados inimigos e, por esse motivo, não podem ser representados por leões; eles ilustrariam disputas de poderes de certo modo equânimes, fato impossível de ocorrer entre caso um dos lados fosse ocupado por esse felino.

\section{Saber - Chacal}

O chacal, assim como o leão, é um dos personagens principais na narrativa-quadro que compõe o primeiro livro do Pañcatantra. Além de sua presença determinante para o desenvolvimento dessa fábula, serão recorrentes as situações em que aparecerá: ao longo dos cinco livros ele será representado treze vezes, em doze fábulas, sendo que apenas no primeiro livro há sete chacais, distribuídos ao longo de seis fábulas. Apresentaremos brevemente as ocorrências deste personagem-tipo no primeiro livro para em seguida verificar o que se pode apreender de sua construção.

Karațaka e Damanaka, em Livro I, narrativa-quadro - “A desunião de amigos”: na fábula os dois chacais interagem e Damanaka é definido, logo no preâmbulo, como um “chacal maledicente e muito ambicioso”. Ao perceber o receio do leão diante de uma voz potente e

\footnotetext{
${ }^{52}$ Fábula/narrativa quadro “A história dos corvos e das corujas” - Livros II e III, p. 107.
} 
desconhecida, Damanaka se aproveita da situação para tentar uma aproximação do poder. Trava, ao longo de toda fábula, diálogos com Karațaka, que tenta constantemente demovê-lo de sua ideia. Ao obter aparente sucesso inicial, descobrindo qual era a fonte do som que incomodava o rei, Damanaka imagina que alçará a postos mais altos e que se posicionará ao lado do rei, como seu conselheiro privilegiado. Esse fato não ocorre, pois o leão, ao invés disso, estabelece laços com o touro. Incomodado com o seu novo esquecimento e com os rumos que a nova amizade vai tomando, Damanaka elabora um novo estratagema para encerrar a relação do leão com o touro, que acaba resultando na morte deste. Karațaka, por sua vez, alerta sempre Damanaka dos riscos que corre ao tomar suas decisões e elaborar seus ardis, e é principalmente por meio do diálogo entre esses dois personagens que surgem as outras fábulas do primeiro livro.

Chacal, em Livro I, fábula IV - “O monge mendicante Devaçarman”: nesta fábula o chacal é brevemente retratado em uma passagem observada pelo monge Devaçarman, na qual dois carneiros, em meio a uma luta, atraem a atenção do chacal. Embora o monge preveja a possível morte do chacal em decorrência do ato impensado de se colocar entre a possível rota de colisão dos dois carneiros, nada pode ser feito, pois, por conta da voracidade de saborear o sangue, aconteceu com o chacal exatamente o previsto pelo monge.

Chacal, em Livro I, fábula VI - “O casal de corvos”: um casal de corvos tem problemas com uma cobra naja, e para tentar resolvê-lo, procura pelo chacal, personagem que não apenas lhes oferece uma estratégia para castigar a cobra como também o faz por meio da narração de uma fábula, em que uma situação similar é ilustrada. O chacal nesta fábula aparece como detentor de conhecimento necessário para resolução de problemas e também como narrador que insere intertextos na obra. $\mathrm{O}$ ardil elaborado pelo chacal é bem-sucedido e o casal de corvos se livra da ameaça constante da cobra sobre suas ninhadas.

Caṇụarava, em Livro I, fábula X - “O chacal Caṇḍarava”: em uma tentativa de fugir do ataque de cães da cidade, Caṇḍarava é banhado por uma tintura azul-índigo e, ao retornar para a floresta, não é reconhecido pelos demais animais. Ao perceber a situação, em que vários animais chegaram até mesmo a fugir, tomados pelo medo, o chacal vislumbra a possibilidade de se aproveitar da situação dizendo a todos que se tratava de um enviado de Brahman; assim, consegue como súditos aqueles a quem antes era submisso e recebe alimento de feras por quem cuja saciedade antes aguardava para só então atacar os restos deixados. Expulsa todos os chacais da floresta para evitar seu reconhecimento, porém, ao ouvir mesmo que a longa distância o 
uivar de um bando de chacais, respondeu ao seu instinto e foi descoberto pelos animais ao seu redor, que o mataram.

Chacal, em Livro I, fábula XI - “O leão Madotkața”: encabeça um ardil que convence o leão a permitir a morte de um camelo para alimentar a ele e aos seus súditos.

Caturaka, em Livro I, fábula XVI - “O leão Vajradam̦șțra”: novamente o chacal que promove um ardil para que um pequeno filhote de camelo que havia crescido ao lado do leão e se afeiçoado a ele seja morto com a sua permissão e a do leão.

Como é possível perceber em praticamente todas as fábulas do Livro I, o personagemtipo chacal está diretamente ligado à elaboração de estratagemas que visam a trazer vantagem para ele ou para outros (embora seja perceptível que a vantagem para si se sobressai), sendo bem-sucedido muitas vezes em seus propósitos. Ele costuma ser possuidor de um saber que se revela útil para situações de sobrevivência ou de caráter político. É importante observar que Damanaka e Karațaka são personagens de extrema importância no primeiro livro, pois são justamente eles os responsáveis pela transmissão da maioria das fábulas que compõem a obra; grande parte delas é trazida ao nosso conhecimento por meio do diálogo travado entre Damanaka e Karațaka, nas sucessivas tentativas de convencimento que um realiza sobre o outro: enquanto Damanaka quer convencer o amigo de que suas ações se fazem necessárias, Karațaka tenta, fábula após fábula, demovê-lo de suas ideias e estratagemas. Não há, no entanto, fábula capaz de impedir Damanaka de dar continuidade aos seus planos e, para cada tentativa de Karațaka, Damanaka tem uma resposta, num embate de conhecimentos que revela Damanaka, se não como o mais sábio, o mais sagaz, melhor manipulador dos saberes que possui. Se considerarmos a função didática como característica das fábulas, não podemos negar que, ao menos no primeiro livro do Pañcatantra, são os chacais os principais responsáveis por esse emprego.

No levantamento de características do personagem-tipo chacal, outra recorrência chama a atenção e merece verificação: em duas das sete fábulas em que este personagem é utilizado no primeiro livro seus instintos o traem: ao entrar, tomado pela voracidade, no meio de uma briga de carneiros, na fábula IV, e ao uivar para lua na fábula V, o chacal é prejudicado. Tal dado é curioso, porém, sem mais amostras dessa ocorrência - que não se repete nos outros livros - pouco se pode afirmar, não sendo possível associá-lo ao personagem-tipo chacal. 
Ao darmos continuidade ao estudo deste personagem-tipo, encontramos diversas outras utilizações dele nos outros quatro livros que compõem o Pañcatantra: além dos sete chacais já mencionados no Livro I, ainda há, ao longo dos outros quatro livros, seis outros chacais ilustrados, sempre em posição destacada, se não de protagonismo. É possível verificar que, embora as fábulas dos demais livros não possuam caráter político tão explicitado como no Livro I, a construção do personagem se mantém a mesma, já que nessas seis fábulas em que o chacal é retratado ele é constantemente representado como sábio, esperto e sagaz, dotado de conhecimentos que podem tanto lhe servir contra perigos como para arquitetar artimanhas que lhe tragam vantagem, ou ainda para aconselhar outros personagens ao seu redor. Apenas em uma das fábulas, a IV do Livro IV, a maneira como o chacal é representado difere do habitual e talvez se aproxime das suposições que se esboçavam anteriormente acerca de seu instinto como elemento constitutivo de tipo: criado em uma família de leões, um filhote de chacal recua diante da possibilidade de se juntar aos seus irmãos em um ataque a um elefante; ao ser objeto de chacota, se ressente contra seus irmãos e, irado, é avisado pela leoa que não faz parte daquela família e advertido a fugir antes que seja destroçado pelos leõezinhos. Embora tenha sido criado como um igual pela família de leões, seu instinto de chacal se mantém e lhe impede de agir como um animal caçador e atacar o elefante. Consequentemente, também não é possível seguir com aquela família, pois sua diferença em relação aos demais se evidencia e revela o risco que ele corre.

Poderíamos nos questionar se, assim como no caso do personagem-tipo leão, também não haveria outros personagens que pudessem representar o saber além do chacal. De fato, se verificarmos todas as fábulas, encontraremos personagens que são qualificados como sábios, tal como o touro Samjĩvaka da narrativa-quadro do primeiro livro (que chega até mesmo a contar fábulas para outros, assim como os chacais) e há até mesmo aqueles que, como a lebre da fábula VIII deste mesmo livro, se utilizam de seus conhecimentos para a elaboração de ardis. Ocorre que nenhum desses animais pode ser equiparado aos chacais pelo fato de que não há, na construção dos personagens de outras espécies, a delicada nuance do apreço pelo poder: a sabedoria e os conhecimentos desses animais, sejam quais forem, nunca são utilizadas com o objetivo de tirar proveito de alguma situação ou de provocar uma aproximação do poder: conforme já foi dito, a lebre, por exemplo, elabora um ardil contra o leão, mas é apenas com o propósito de salvar sua vida que se encontra em risco iminente e a dos demais animais da floresta, sem que, no entanto, pretenda assumir o lugar de poder ocupado pelo leão. Da mesma forma o touro, mesmo detentor de saberes elaborados e até mesmo refinados, não se abala pela 
proximidade do poder nem se deixa levar por essa circunstância, mantendo uma amizade desinteressada com o leão Piñgalaka. Ainda poderíamos citar outros animais, mas nenhum deles exibiria nem a importância nem a recorrência que o personagem-tipo chacal apresenta.

É interessante observar, por meio de um levantamento quantitativo, que em grande parte das fábulas em que aparece um leão ou um chacal, eles estão associados de alguma maneira, mesmo que essas fábulas não sejam, necessariamente, de caráter político. Dentre as diversas fábulas que compõem o Pañcatantra, são retratados onze leões e treze chacais, sendo que em oito fábulas (que se encontram concentradas especialmente nos livros I e IV) há o relacionamento entre os dois personagens. Este relacionamento pode ocorrer de diversas formas, mas se dá majoritariamente - conforme já fora mostrado - na elaboração de alguma artimanha da parte do chacal contra o leão. As artimanhas têm os fins mais variados, seja a aproximação do poder, a obtenção de vantagem em alguma situação ou mesmo a fuga de uma situação de risco, mas evidenciam sempre uma tensão entre poder e saber, na qual o poder sempre se impõe e o saber sempre tenta - e muitas vezes consegue - manipulá-lo. 


\section{Capítulo II}

\section{Sobre o livro de Kalīla e Dimna}

\section{Dois chacais: sagacidade e decoro ao invés de cinco tratados sobre a conduta}

Segundo a tradição, o livro de Kalīla e Dimna foi traduzido ao árabe ${ }^{53}$ por volta de VIII d.C., mas não existe uma edição crítica dessa tradução pois há uma série de manuscritos divididos em seis famílias - que dificultariam muito esse procedimento. Ainda seguindo essa tradição, com as ressalvas já explicitadas no capítulo anterior, adota-se, na maioria das vezes, o escriba 'Abdullah Ibn-Almuqaffac como responsável pela obra. O autor teria vivido em contato privilegiado tanto entre os omíadas como entre os abássidas, ocupando a posição de letrado em ambas as cortes, mas, segundo registros históricos - por vezes tão fantasiosos quanto as fábulas que aqui estudamos - teria morrido vítima justamente de intrigas palacianas, o que não deixa de ser um fim bastante curioso, tendo em vista o paralelo que pode ser feito em relação aos fabulários estudados - poder e saber se aproximam, em condições que podem apresentar risco a ambos mas que, invariavelmente, acabam trazendo mais danos aos letrados.

Segundo se verifica nos manuais de literatura árabe, Ibn-Almuqaffa ${ }^{\mathrm{c}}$ teria dedicado boa parte de sua atividade à tradução de obras do pehlevi e do grego e às obras originais $a$ ' $a d a b$ alkabīr (Grande Literatura ${ }^{54}$ ), al-‘adab așsaḡīr (Pequena Literatura), Epístola sobre os companheiros [do potentado] e o Livro da coroa sobre a conduta de [Kisrà] Anū Xirwān. Contava, para isso, com a ascendência da importância dos escribas, que vinha em um crescente desde o império Omíada e encontrava seu auge no império abássida. Segundo Juan Vernet ${ }^{55}$, o desenvolvimento da prosa literária árabe se dá em consonância com o triunfo do Islamismo, pois, com ele, desaparecem os oráculos e sacerdotes que se utilizavam de prosas rimadas para lançar seus feitiços. Até então, a poesia era mais disseminada e contava com um público maior que a prosa, além de já se ancorar em uma tradição mais sólida.

\footnotetext{
${ }^{53}$ IBN ALMUQAFFA', Kalīla e Dimna, op. cit, p. XVIII.

${ }^{54}$ É necessário apontar que o termo adab tem uma possibilidade bastante ampla de traduções, ao que Jarouche (2005) aponta, além de "literatura”, "boa conduta”, "bons modos”, “urbanidade”, “cortesia”, “decoro” e Juan Vernet (1972) ainda explica que o valor semântico da palavra sofreu flutuações ao longo dos séculos, e que "significa en una primera aproximación al conjunto de disciplinas necesarias que dan la cultura general para desenvolverse en la vida o, en sentido más restringido, em el ejercicio de un cargo”.

${ }^{55}$ VERNET, J. Literatura árabe. Barcelona: Editorial Labor, S.A. 1962, p. 91.
} 
Consta em alguns estudos ${ }^{56}$ que Ibn-Almuqaffa ${ }^{c}$, persa convertido tardiamente ao Islamismo, fora encarregado de traduzir a versão pehlevi do Pañcatantra ao árabe pelo próprio califa Abū Jafar Almansur, segundo da dinastia abássida, cujo governo foi reconhecido pela valorização do conhecimento e erudição, e graças ao qual diversas áreas das ciências e do saber floresceram no mundo árabe. Foi um período de crescimento cultural inestimável o que serviu de contexto para a produção do livro de Kalīla e Dimna, e grande parte desse conhecimento se baseou na cultura e legado persa, que foi, ironicamente, destruído pelos árabes ${ }^{57}$. Note-se, todavia, nas fontes antigas não existe comprovação de que tal tradução tenha sido feita a pedido do califa, sendo mais verossímil pensar que se trata antes de especulação.

Não nos deteremos aqui em um aprofundamento nas diversas contendas que envolvem a produção do livro por acreditar que elas são infrutíferas para as finalidades pretendidas, e acreditamos que o que já foi dito a respeito das discussões sobre a obra atende aos propósitos de apresentação do fabulário. Limitamo-nos a apresentar o levantamento realizado por Jarouche em Vicissitudes de um livro e de seu autor, pois consideramos que ele já expõe com bastante clareza quais são as diversas fontes em que se baseia a composição do livro de Kalīla e Dimna:

2) O livro de Kalīla e Dimna propriamente dito apresenta a seguinte distribuição de capítulos do manuscrito de 1221: I) "O leão e o touro"; II) "Investigações sobre Dimna”; III) “A pomba de colar"; IV) "As corujas e os corvos"; V) "O macaco e o cágado"; VI) "O leão e o mangusto"; XII) "O viajante e o joalheiro"; XIII) "O filho do rei e seus amigos”; XIV) "A leoa e o animal xachar"; e XV) "O asceta e o hóspede”. Alguns manuscritos mais recentes apresentam, ademais, dois outros capítulos: XVI) “A garça e a pata”; e XVII) "A pomba, a raposa e a garça”, ambos os quais constam da tradução espanhola de 1251, o que indica a antiguidade com que foram incorporados ao livro.

3) Versões dos capítulos I, III, IV, V, VI e uma parte do XII foram localizados no Pañcatantra, coletânea bramânica da Índia antiga composta em sânscrito, e numa outra do século XI d.C., o Hitopadeça (este, na verdade, uma recompilação tardia do mesmo Pañcatantra). E versões dos originais IX, X e XI foram encontrados na epopeia sânscrita Mahãbhãrata. Além disso, há outros três capítulos de fonte presumivelmente (pois os originais não foram encontrados) indiana: o VII (do qual se localizou uma tradução tibetana, um século mais antiga do que a árabe) e o XIII; ambos, VII e XIII, pertencem à tradição budista. Também de origem supostamente indiana, mas pertencente à tradição bramânica, é o capítulo XIV. Tem-se por certo que os capítulos II, VIII, XV, XVI e XVII são árabe-muçulmanos ${ }^{58}$.

Como é possível observar, reduzir a obra árabe a uma cópia é não considerar a riqueza com que ela se constitui e ignorar nela elementos genuínos do patrimônio cultural muçulmano,

\footnotetext{
${ }^{56}$ ANÔNIMO. Pañcatantra. Tradução de Edouard Lancereau. Paris: Éditions Gallimard/UNESCO, 1965, p. 27.

57 Ibid.

${ }^{58}$ IBN ALMUQAFFA ${ }^{\mathrm{C}}$, Kalīla e Dimna. Tradução, organização, introdução e notas de Mamede Mustafa Jarouche. São Paulo: Biblioteca Martins Fontes, 2005, p. XLIV.
} 
pois, mesmo quando as fontes são outras, dá-se a elas tratamento muito próprio e se adotam liberdades compositivas bastante peculiares. A seguir, abordaremos algumas dessas diferenças.

\section{Um único Deus para Kalīla e Dimna}

Ao darmos início à leitura da principal versão do livro de Kalīla e Dimna adotada para realização deste trabalho, já podemos observar um aspecto em que destoa claramente do compêndio Pañcatantra: ela se inicia ${ }^{59}$ com o louvor a Deus, o misericordioso, o misericordiador, e a declaração de que não há divindade senão Deus, para que, em seguida, o autor rogue pela salvação no dia do juízo final e declare Muhammad servo e apóstolo de Deus, “criado para conduzir ao bom caminho: quem o seguir triunfará" ${ }^{60}$. O autor da tradução ainda nos permite entrar em contato com uma outra versão, de um texto utilizado como apoio em seu trabalho graças à antiguidade do manuscrito ${ }^{61}$, datado de 739 H./1339 d.C., e nesta versão podemos verificar uma ainda mais exaltada religiosidade islâmica, da qual destacamos a passagem:

Declaro que não há divindade senão Deus, único e sem assemelhado, o qual é louvado pelas línguas em todas as linguagens. E declaro que Muhammad é seu servo e enviado, e seu mistério no círculo da criação, distinguido com a ascensão [aos céus] e a audição da convocação [divina] por todos os lados. Que as bênçãos de Deus sejam sobre ele, sobre seus parentes e sobre seus companheiros enquanto existirem a terra e os céus. ${ }^{62}$

Ao contrapor essas aberturas e o início do prólogo de Pañcatantra, conseguimos observar a mudança de foco em relação à religião. Embora seja possível notar que os dois fabulários apresentam essa característica e dão à religião um lugar bastante privilegiado, não apenas nas aberturas das obras, mas ao longo delas, cada um dedica uma abordagem específica ao tema: enquanto a obra indiana invoca divindades do universo religioso bastante numeroso dos indianos, a árabe louva, roga por proteção e salvação a apenas um deus, o islâmico e, além disso, nega a existência de outras divindades.

\footnotetext{
59 Assim começa a versão denominada A pela edição brasileira adotada como base da tradução e fundada no manuscrito mais antigo, de 1221 d.C.. Há uma variante desse começo, denominada B e datada de 1339 d.C., que seria, aparentemente, uma combinação da abertura de A e do capítulo Propósito do livro, por 'Abdullah Ibn Almuqaffac.

${ }^{60}$ IBN ALMUQAFFAc, Kalīla e Dimna. Tradução, organização, introdução e notas de Mamede Mustafa Jarouche. São Paulo: Biblioteca Martins Fontes, 2005, p.03.

${ }^{61}$ Ibid., p. XIII.

62 Ibid., p. 287.
} 
Cabe aqui situar histórica e religiosamente a elaboração do livro árabe. Meados do século VIII d.C. se referem também ao século II da Hégira, ou seja, o segundo século após a fuga de Muhammad de Meca para Medina, em 622 da era cristã, que marca o ano inicial do calendário muçulmano. Este dado evidencia o caráter religioso presente na abertura da obra e ressalta mais uma diferença entre os dois fabulários: se o indiano circulava em uma sociedade politeísta, o árabe apaga esse traço e o substitui pela profissão de fé monoteísta do Islã, ao afirmar que não há outra divindade senão "Deus, único e sem assemelhado” ${ }^{63}$. Esse procedimento pode ser analisado não apenas sob um ponto de vista religioso, mas também político, pois, se considerarmos o contexto histórico de produção da obra, perceberemos que o islamismo, tanto para se firmar como para ser disseminado, contava com o apagamento das outras religiões que tinham presença bastante forte nos territórios da região até pouco tempo. O califado abássida, que baseava a estruturação de seu poder principalmente no fato de ser composto por descendentes da linhagem de Muhammad ${ }^{64}$, ao se voltar para a constituição de uma cultura e tradição genuinamente árabe-islâmica possivelmente se utilizara dessa estratégia tanto para enfraquecer vestígios de outras religiões como para se fortalecer e fortalecer o islamismo, se utilizando de um corpus que já tinha atestada recepção e dando a ele características árabe-islâmicas.

Nos textos introdutórios que seguem, quaisquer alusões feitas ao fabulário originário da Índia se referem a sábios, filósofos ou quando muito ascetas, desconsiderando a existência de brâmanes e apagando quaisquer traços alusivos ao universo religioso indiano. O fabulário árabe segue na mesma linha, sempre que possível, sem a presença de referências à religiosidade indiana, recorrendo em seu lugar continuamente a Deus e ao islamismo para introduzir qualquer olhar religioso nas narrativas e, com isso, conferindo uma característica genuinamente cultural à obra. Só são abertas exceções em casos de fábulas que exijam a presença de brâmanes e de vocabulário religioso congruente para que suas dinâmicas e coerências interiores não sejam corrompidas, como é o caso, por exemplo, da fábula de “Iblād, Īrāĥt e Xārdam, rei da Índia”, que sequer consta do Pañcatantra, sendo, provavelmente, de outra fonte ${ }^{65}$. De fato, seria pouco plausível que a narrativa em questão pertencesse ao Pañcatantra, pois se trata, sobretudo, de

\footnotetext{
${ }^{63}$ IBN ALMUQAFFAc, Kalīla e Dimna. Tradução, organização, introdução e notas de Mamede Mustafa Jarouche. São Paulo: Biblioteca Martins Fontes, 2005, p. 03.

${ }^{64}$ Dinastia que descende de Al 'Abbas ibn 'Abdl al-Muttalib, tio do Profeta.

${ }^{65}$ A fábula consta nas versões siríacas e tibetanas, mas não consta na versão sânscrita.
} 
um ataque aos brâmanes, que são apontados como ardilosos e não confiáveis ${ }^{66}$ e que buscam, por meio de um estratagema, fazer mal ao rei, forçando-o a matar os seus. É interessante observar a sua inserção no fabulário Kalīla e Dimna por reforçar a hipóteses de que os apagamentos da religiosidade indiana não apenas eram deliberados como se pretendia, além disso, atribuir a ela um valor negativo.

Uma outra mudança bastante significativa nesta direção pode ser apontada na abertura do prólogo-moldura do fabulário árabe: se antes - no compêndio indiano - ele aludia a uma conversa entre um rei da Índia e um brâmane chamado Viṣnuçarman (ou “aquele que detém o saber”), no fabulário árabe observamos não apenas a mudança do nome como a redefinição do posto do sábio, que deixa de ser tratado como brâmane, ou seja, tem sua característica religiosa apagada, para ser apenas filósofo ou “sábio Baydabā”, como é mencionado em O leão e o touro e Investigação acerca de Dimna.

\section{O propósito do livro}

Além do que expusemos sobre as referências à religião, é possível apontar, no início do fabulário árabe, capítulos introdutórios que não constam do Pañcatantra, mas que fazem alusão a ele: Propósito do livro, por ${ }^{\mathbf{c}}$ Abdullah Ibn Almuqaffac ${ }^{\mathrm{c}}$, O envio do médico Burzuwayh à Índia pelo rei Kisrà'Anū Xirwān e O médico Burzuwayh, nas palavras de Buzurjmihr Ibn Albahtikan. A seguir, analisaremos peculiaridades de cada um desses capítulos.

O livro de Kalīla e Dimna não apresenta apenas um prólogo, mas uma série de textos introdutórios, e todos esses textos tratam de dar um propósito conciso à composição do tratado, justificá-lo e enobrecê-lo, conforme parâmetros que já foram explicitados anteriormente. Daremos atenção aqui ao capítulo Propósito do Livro, por 'Abdullah Ibn-AlMuqaffac, por apresentar características consideradas relevantes para o estudo em questão e que em muito se diferenciam das do fabulário indiano.

Como o título já indica, esse capítulo se dedica a estabelecer o propósito do livro, como exposto no trecho a seguir:

\footnotetext{
66 “Não permitas que teus inimigos se regozijem, sejam eles os brâmanes ou outros quaisquer, e fica ciente de que jamais te darão bons conselhos [...]”, IBN ALMUQAFFAc, Kalīla e Dimna. Tradução, organização, introdução e notas de Mamede Mustafa Jarouche. São Paulo: Biblioteca Martins Fontes, 2005, p. 182.
} 
Este é o livro de Kalīla e Dimna, composto pelos sábios da Índia a partir de paradigmas e histórias mediante os quais procuraram lograr a maior eloquência no discurso, na direção por eles pretendida. Os homens inteligentes de todas as épocas sempre estão em busca do que os faça ser compreendidos: para tanto, entabulam várias espécies de artimanhas e intentam dar a conhecer os argumentos que possuem. Isso os levou à composição deste livro, no qual condensaram os mais eloquentes e elaborados discursos na boca de aves, alimárias e feras, concatenando, aí, duas questões: quanto a eles, encontraram um lugar para dispor o discurso, e vertentes para percorrer; quanto ao livro, reuniu sabedoria e diversão. ${ }^{67}$

O trecho destacado é considerado especialmente importante para este trabalho porque esclarece não apenas o propósito do livro segundo o aludido autor Ibn Almuqaffac ${ }^{c}$, mas, além disso, expõe qual seria o propósito pretendido pela fábula como gênero narrativo: “os homens inteligentes de todas as épocas” (2005), recorrem à fábula para abordar assuntos de naturezas diversas - inclusive de natureza política -, pois, por meio da narração de situações paradigmáticas vividas por “aves, alimárias e feras”, podem, de maneira bastante eloquente, desenvolver ideias e expor argumentos que tanto convencem como agradam.

É interessante apontar uma outra mudança contida nos parágrafos iniciais deste capítulo, talvez fruto do tempo e da recepção da obra, ou de mais uma tentativa de lhe imputar um caráter nobilitado: os sábios não seriam apenas os compositores da obra, mas também, segundo o que consta neste capítulo, parte do público que procurava o fabulário para obtenção de conhecimento. Conforme é possível depreender da passagem "os sábios elegeram-no por causa da sabedoria, e os néscios, por causa da diversão" ${ }^{68}$, o livro passava a se propor como adequado a dois públicos bastante diferenciados, em um acréscimo em relação ao Pañcatantra, que, em seu prólogo, se apresentava como um livro direcionado àqueles que precisavam acumular muito saber em pouco tempo, e, ainda mais, circulava pelo mundo “com o propósito de educação dos jovens” ${ }^{69}$.

Retornando ao trecho destacado, é possível observar que ele contém diversos sinais relevantes, tal como no início, a referência ao fabulário de Kalīla e Dimna como um livro “composto por sábios” e, poucas linhas adiante, a referência às fábulas como recurso discursivo de "homens inteligentes de todas as épocas”. Esses sinais por si sós tentam induzir o leitor a crer que as fábulas são concebidas apenas pelos mais sábios, ou seja, enaltecem a sua produção e nos levam a imaginar que é um gênero a que recorrem os mais gabaritados. É necessário

\footnotetext{
${ }^{67}$ IBN ALMUQAFFA' ${ }^{c}$ Kalīla e Dimna. Tradução, organização, introdução e notas de Mamede Mustafa Jarouche. São Paulo: Biblioteca Martins Fontes, 2005, p. 05.

${ }^{68}$ Ibid.

${ }^{69}$ ANÔNIMO. Pañcatantra: Fábulas Indianas - Livro I. Tradução de Maria da Graça Tesheimer; Maria Valíria Aderson de Mello Vargas; Marianne Erps Fleming. 2. Ed. São Paulo: Humanitas, 2004, p. 25.
} 
relembrar que mesmo os capítulos introdutórios, por estarem ligados ao livro de Kalīla e Dimna, poderiam configurar estratégias narrativas utilizadas pelo próprio “autor”, com o intuito de elevar a obra. Não seria de estranhar que, conhecendo as diversas estratégias narrativas contidas no fabulário, delas se dispusesse com propriedade e desenvoltura, sem que, para isso, necessitasse admitir tal utilização. De fato, ao longo da leitura do capítulo essa hipótese se reforça, pois estão nele contidas já uma série de fábulas como “O homem e o tesouro" "70, "O dorminhoco e o ladrão"71 ou "O pescador e a pérola”72 e, além disso, máximas também bastante comuns em todo o fabulário, como “[...] se diz que duas coisas ninguém deve ter em pouca conta: o decoro e a morte"73. O modo como essas fábulas e máximas são inseridas no “propósito” da obra são absolutamente similares à utilização delas no fabulário.

Ainda levando em consideração o gênero narrativo a que pertence, pode-se verificar no trecho citado que o fabulário foi escolhido para condensar "os mais eloquentes e elaborados discursos na boca de aves, alimárias e feras" 74 e aqui se apresenta mais uma das características do trabalho: a escolha dos personagens. No início do trecho nota-se que a opção por colocar “mais eloquentes e elaborados discursos” na "boca de aves, alimárias e feras” não é aleatória, já que essa é uma das variadas artimanhas que "os homens inteligentes de todas as épocas” colocam em prática para “dar a conhecer os argumentos que possuem”. Ora, o uso de "aves, alimárias e feras” como personagens visa a atingir, se não o conhecimento, a diversão, pois, ao colocar animais de diversas espécies vivendo situações que podem ser facilmente espelhadas em situações vividas por humanos, se não fossem bem-sucedidos no intento de dar a conhecer suas ideias, os sábios causariam como efeito igualmente almejado o contentamento e o deleite na audição/leitura. Voltando à ideia de artimanha, ela parece indicar que se trata de uma obra de sábios para sábios (reafirmando o público explicitado anteriormente como acrescido em relação ao compêndio indiano); isso é o essencial, pois apenas os sábios entenderiam que dois aspectos aparentemente incongruentes segundo as tópicas que os constituem, sabedoria e diversão, estariam contidos num mesmo objeto.

Tais apontamentos não encontram espelhamento na obra indiana. Como foi observado anteriormente, o prólogo do Pañcatantra não se propõe a discutir nada que se refira à

\footnotetext{
${ }^{70}$ IBN ALMUQAFFA', Kalīla e Dimna. Tradução, organização, introdução e notas de Mamede Mustafa Jarouche. São Paulo: Biblioteca Martins Fontes, 2005, p. 06.

${ }^{71}$ Ibid, p.07.

${ }^{72}$ Ibid, p.16.

${ }^{73}$ Ibid, p.07.

${ }^{74}$ Ibid, p.05.
} 
composição dos cinco tratados ou justificar suas estratégias compositivas. Embora neles também se apresentem os mesmos elementos, não se verifica a necessidade de explicá-los. Assim, não se encontra na obra indiana justificativa para a utilização de animais antropomorfizados, nem para o uso de narrativas fictícias para tratar de temas como política e outros de similar importância.

O fato de não serem dadas justificativas no prólogo da obra indiana e, em contrapartida, um capitulo introdutório inteiro ser dedicado a este tema no livro de Kalīla e Dimna expõe uma diferença que pode ser atribuída a uma série de fatores, dos quais os mais plausíveis devem ser, primeiro, a questão religiosa, na qual a antropomorfização estava na esfera do mito (Hurāfa) que deturpa a verdadeira fé, e, segundo, e em decorrência do primeiro, a necessidade de estabelecer a importância e relevância do gênero e de suas estratégias. É possível que, na época e no contexto em que foram elaboradas as primeiras fábulas indianas, essa importância não fosse questionada, passando a ser necessária ao longo do tempo, de tal forma que, anteriormente, ao se apresentar o fabulário indiano como manual de conduta e decoro, tal argumento por si só já justificasse seus procedimentos e validasse a sua leitura, mas que, em outros momentos históricos e outras sociedades, tais justificativas não fossem mais suficientes, carecendo de outras, cada vez mais elaboradas, para nobilitar o gênero. Encontramos reforços para essa hipótese no fato de que a própria crítica da época tratava, muitas vezes, de diminuir os méritos do fabulário árabe, como é possível observar na passagem "e entre as histórias forjadas, e as notícias falsificadas e ornamentadas, está o livro de Kalīla e Dimna"75. Aparentemente, a assumida ficcionalidade da obra era desmerecida - e talvez por isso precisasse ser defendida como uma opção válida e adequada -, pois, segundo Jarouche em Conselhos e agruras de um chacal letrado, posfácio da obra O leão e o chacal Mergulhador, determinadas teorizações da época "desqualificavam a narrativa ficcional como forma inferior de conhecimento". ${ }^{76}$

Vale ainda apontar que o capítulo se justifica como necessário na passagem:

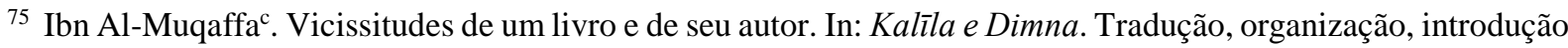
e notas de Mamede Mustafa Jarouche. São Paulo: Martins Fontes, 2005, p. XXXVI.

${ }^{76}$ ANÔNIMO. O leão e o chacal Mergulhador. Tradução de Mamede Mustafa Jarouche. São Paulo: Editora Globo, 2009, p. 201.
} 
De fato, quando verificamos que os persas traduziram este livro, passando-o da língua indiana para a persa, anexamos este capítulo em árabe a fim de que seja o alicerce mediante o qual se esclareça o que é este livro para quem o pretenda ler, compreender e citar. ${ }^{77}$

Estabelecendo-o deliberadamente como um acréscimo árabe e entendendo serem necessários contextualização e encaminhamento de leitura, o capítulo aponta para uma diferença na recepção da obra: sábios ou néscios, que fossem, precisavam de alguma preparação para a leitura da obra, que, anteriormente, não havia se verificado necessária.

É adequado dizer, por fim, algumas palavras sobre um ponto que se relaciona aos outros já indicados: ao visto, era necessária também a indicação de como ler a obra, pois, segundo IbnAlmuqaffac ${ }^{c}$, se impunha de pronto a quem procurasse pelo fabulário "iniciá-lo por uma boa e perseverante leitura; não seja o seu propósito atingir-lhe o final sem o ter bem compreendido, pois, do contrário, a leitura não lhe trará benefício nem terá utilidade alguma»78, num evidenciamento último de que, embora abarcasse dentro das possibilidades de leitor o néscio, mesmo este deveria assumir uma outra postura diante do livro, apesar de o deleite ser um aspecto tão desejado como o conhecimento.

\section{O médico e o saber}

No capítulo introdutório O envio do médico Burzuwayh à Índia pelo rei Kisrà'Anū Xirwān ${ }^{79}$, um rei da Pérsia, conhecido por sua sabedoria, justiça e bom parecer, "no auge de seu governo e no esplendor de seu poder” ${ }^{80}$ toma ciência da existência de um livro indiano "por sábios elaborado, por eruditos composto e por sagazes disposto: de capítulos coordenados, suas maravilhas foram registradas na boca de aves, alimárias, animais selvagens, feras, répteis e insetos rasteiros” ${ }^{81}$, e decide obtê-lo, a fim de aperfeiçoar sua ação política. Com tal propósito, envia um médico - assim como a escolha pelo brâmane na introdução indiana, lembramos que o médico também é um símbolo de sabedoria - para conquistar a confiança dos sábios indianos detentores da obra e, assim, obtê-la.

\footnotetext{
${ }^{77}$ Ibn Al-Muqaffac. Propósito do livro, por 'Abdullah Ibn Almuqaffac. In: Kalīla e Dimna. Tradução, organização, introdução e notas de Mamede Mustafa Jarouche. São Paulo: Martins Fontes, 2005, p.17.

${ }^{78}$ IBN ALMUQAFFA', Kalīla e Dimna. Tradução, organização, introdução e notas de Mamede Mustafa Jarouche. São Paulo: Biblioteca Martins Fontes, 2005, p. 06.

${ }^{79}$ Ibid. p.19.

${ }^{80}$ Ibid. p.20.

${ }^{81}$ Ibid.
} 
Deste capítulo é plausível inferir que o "livro indiano" seja o próprio Pañcatantra, porém, conforme dito anteriormente, são apagados os traços religiosos do fabulário, que deixa de ser composto por um brâmane para ser "por sábios elaborado, por eruditos composto e por sagazes disposto". ${ }^{82}$ Ao longo da leitura o livro é referido como "o livro de Kalīla e Dimna, que é propriedade dos reis de lá [Índia], e foi elaborado pelos sábios, polido pelos eruditos e fixado pelos sagazes; as bibliotecas dos reis não possuem nada semelhante, e os reis da Índia nele se apoiam quando ocorrem problemas graves” ${ }^{83}$, e entendemos que as raízes do livro estão sendo situadas: Kisrà'Anū Xirwān é a forma árabe do nome do rei sassânida da Pérsia, Hosrau Nuxirvan (531-579 d.C.) e, ao que nos informa o texto introdutório, foi o responsável por trazer o texto indiano ao pehlevi, incumbindo, para tal finalidade, o médico Burzuwayh. Entre as diversas versões dos manuscritos é possível encontrarmos diferentes justificativas para tal feito: na principal versão trabalhada aqui, a motivação para a busca pelo livro é política, como podemos deduzir da passagem:

E quando ele [rei Kisrà'Anū Xirwān] estava no auge de seu governo e no esplendor de seu poder, eis que recebeu a notícia de que havia na Índia um livro - por sábios elaborado, por eruditos composto e por sagazes disposto: de capítulos coordenados, suas maravilhas foram registradas na boca de aves, alimárias, animais selvagens, feras, répteis e insetos rasteiros - do qual necessitavam os reis para conduzir seu rebanho, atender suas demandas e fazer-lhe justiça, pois o rebanho não fica em bom estado senão com a boa condução dos reis e sua benevolência, compaixão e misericórdia. ${ }^{84}$

Contudo, existem outras justificativas, como as antiga versão espanhola do século XIII, editada por Antonio G. Solalinde em 1917:

Dicen que en tiempo de los reyes de los gentiles, reinando el rey Sirechuel, que fue fijo de Cades, fue un homne a que decían Berzebuey, que era físico e príncipe de los físicos del regno; e había con el rey grant dignidad e honra, e cátedra conoscida. Et como quier que era físico conoscido, era sabio e filósofo, et dio al rey de India una petición, la cual decía que fallaba en escripturas de los filósofos que en tierra de India había unos montes en que había tantas yerbas de muchas maneras, e que si conoscidas fuesen e sacadas e confacionadas, que se sacarían dellas melecinas con que resucitasen los muertos; e fizo al rey que le diese licencia para ir huscarlas, et que le ayudase para la despensa, e que le diese sus cartas para todos los reyes de India, que le ayudasen por que él pudiese recabdar aquello por que iba. ${ }^{85}$

\footnotetext{
${ }^{82}$ IBN ALMUQAFFA', Kalīla e Dimna. Tradução, organização, introdução e notas de Mamede Mustafa Jarouche. São Paulo: Biblioteca Martins Fontes, 2005, p. 20.

${ }^{83}$ Ibid., p. 22.

${ }^{84}$ Ibid., p. 20.

85 SOLALINDE, A. G. Calila y Dimna, fábulas; antigua version castellana. Madrid: Calleja, 1917. 293 p. Disponível em: <http://www.dominiopublico.gov.br/download/texto/bk000006.pdf>. Na verdade, tal justificativa se encontra no Shah Nama, “o livro dos reis”, do letrado e poeta persa Alfirdusi.
} 
Ao término da busca, Berzebuey (variação de Burzuwayh) descobre que as ervas que na verdade procurava eram as palavras de sabedoria do livro de Kalīla e Dimna, e que os mortos que ressuscitavam eram os néscios que, ao terem acesso àquelas palavras, renasciam para o mundo.

Independentemente da versão, é possível observar o emprego de uma narrativa provavelmente fictícia que precede e justifica a composição do livro, tal como foi verificado no prólogo do fabulário indiano. Assim como aquele, este capítulo, onde quer que o busquemos, também é dotado de inúmeros elementos que reforçam a ideia de que o fabulário procurava para si - por meio de artifícios retóricos - características que o valorizassem, como a presença do médico, de sábios, reis e o tratamento do conteúdo do livro como "valioso decoro", entre outros.

Dando continuidade ao estudo da versão escolhida, é interessante observar a forma como ela constrói as figuras do rei e do sábio, preenchendo-as de símbolos nobres e, de certa forma, apontando para a necessidade do estabelecimento de uma relação entre eles (que se verificará adiante, na obra, porém com outros desenlaces): tanto o rei como o médico/sábio são descritos da maneira mais lisonjeira possível, e a relação positiva entre eles rende frutos a ambos, o reconhecimento para o sábio - que recebe um capítulo, o próximo, em sua homenagem e reverência - e o sucesso da empreitada do rei, que obtém o livro de Kalīla e Dimna e dele passa a fazer uso, beneficiando os seus. Ao término do capítulo, podemos ver inclusive que o reconhecimento dos méritos do sábio se faz para que funcione como "um estímulo à obediência aos reis”86, no enlace de uma relação que parece, tal como as fábulas, apresentar uma moral. Se, na obra, efetivamente, entramos em contato com uma situação em que um personagem, embora sábio, procura a proximidade do rei por meio de artimanhas, e é punido pelo mal que faz, parece que, sutilmente, obtemos neste capítulo a ideia de que uma outra postura do sábio pode resultar, em contrapartida, na sua consideração e exaltação. Embora este capítulo não conte com a inserção de narrativas, podemos dizer que ele, assim como as fábulas, tem finalidades moralizantes, podendo ser lido ele todo como uma.

Por fim, e, para reforçar nossas suposições, deixamos a passagem que encerra o capítulo:

Assim, quem ler este livro deverá conhecer o motivo pelo qual foi elaborado Kalīla e Dimna, e levado da terra da Índia para a terra da Pérsia; que conheça ainda a superioridade dos reis e da

\footnotetext{
${ }^{86}$ IBN ALMUQAFFAc, Kalīla e Dimna. Tradução, organização, introdução e notas de Mamede Mustafa Jarouche. São Paulo: Biblioteca Martins Fontes, 2005, p. 28.
} 
submissão a eles, pondo-as acima dos demais misteres, e que saiba que honrado é quem os reis honram e elevam em seu governo. ${ }^{87}$

\section{O médico e a religião}

No último capítulo introdutório - ou poderíamos dizer que já estamos, de certa forma, na produção do fabulário? - encontramos, conforme fora anunciado, as honrarias ao médico Burzuwayh, tido como o "mais eminente médico da Pérsia”"88. Entramos em contato com sua história e com o fato de que, ao longo da vida, o médico vai lidando com entraves que contrapõem seus conhecimentos de medicina e a opção por se dedicar à uma religião. Conforme vai seguindo, percebe não haver motivos para adotar nenhuma das religiões que se põe a observar, mas mesmo assim o tema o persegue e incomoda por muito tempo: ele chega a seguir a religião de seus pais, mas, após certo tempo, descobre que nem mesmo naquela religião encontrava solução, nem motivo, e muito menos justificativa. Percebemos, ao fim de sua história, que termina por se concentrar em consertar suas ações para a vida eterna - aceitando, de certa forma, a religião, que não chega a ser nomeada, e a Deus - e que, além disso, também mantém seu laço com o conhecimento, se dispondo a disseminá-lo.

O que mais nos chama a atenção no capítulo é o fato de que as religiões - que existiam em grande diversidade - vão sendo relativizadas e desmerecidas, e, embora não seja possível afirmar com exatidão, aparentemente o médico encontra a conciliação entre religião e conhecimento com o entendimento de que há um Deus único a quem ele deve seguir respeitando, o que pode levar algum incauto a supor que esteja se referindo ao islamismo. Essa conjectura se baseia também no fato de que a única religião que é de fato mencionada e reverenciada no livro de Kalīla e Dimna é a islâmica, mas seria anacrônico e inverossímil, obviamente, referi-la nessa altura da narrativa; ao mesmo tempo, essa figura tão dotada de características elevadas e responsável pela tradução do livro ao pehlevi já descartara seguir o zoroastrismo da família; portanto, a profissão de fé parece apresentar um cunho antes panteísta. Pode-se pensar, ainda, como fez, entre outros, o erudito Albiruni, que as palavras atribuídas a Burzuwaiy fossem, na verdade, do próprio Ibn Almuqaffac ${ }^{c}$, o qual, a um só tempo, apagaria as marcas da religiosidade indiana (cultura adversária, desde sempre, da persa) e relativizaria

${ }^{87}$ IBN ALMUQAFFAc ${ }^{c}$ Kalīla e Dimna. Tradução, organização, introdução e notas de Mamede Mustafa Jarouche. São Paulo: Biblioteca Martins Fontes, 2005, p. 28.

${ }^{88}$ Ibid., p. 29. 
outras, entre as quais, de maneira indireta, a muçulmana (isso depois de haver depreciado a religiosidade persa, zoroastrista).

Redundante dizer que este capítulo introdutório lança mão das mesmas estratégias que serão encontradas adiante no fabulário. Também o médico, ao expor sua história ao escriba, recorre às narrativas fábulares e máximas, aproximando-se do tom do livro que traduziu, e reafirmando na recepção a ideia de que todo ele fora pensado de acordo com estratégias de convencimento a fim de se fazer uma leitura não apenas desejável como necessária.

Encerrados os apontamentos sobre os capítulos introdutórios, nos deteremos agora em analisar o modo como as narrativas estão dispostas no livro de Kalīla e Dimna. Seria admissível fazer o mesmo procedimento retroativamente, pois, como dissemos, já nos capítulos que antecedem o compêndio é possível observar a utilização de estratégias narrativas similares, porém, vamos nos ater ao tratamento dado especificamente ao que se determina como "o livro de Kalīla e Dimna” pois, além desses capítulos serem apresentados admitidamente como acréscimos em relação ao "livro de Kalīla e Dimna, composto pelos sábios da Índia” 89 , não se assumem como ficcionais e, por isso, não vamos estudá-los sob esse viés.

\section{Pensando as narrativas árabes}

É interessante observar que a maioria das fábulas deste livro se apresenta da mesma forma, em que um personagem, diante de determinada situação, se refere a um breve resumo de uma situação similar - normalmente, já apresentando seu desfecho -, com a intenção de aconselhar - seja para demover, seja para incentivar -, e aquele com quem ele dialoga lhe pergunta “e como foi essa história?”; diante de tal questão, se apresenta a narrativa. Oferecemos a seguinte passagem apenas para ilustrar o recorrente recurso:

Disse o chacal: "é o pior dos estratagemas este que pretende adotar! Procura algo com o qual logres teu intento sem que sofras dano algum. E muita cautela para que o teu paradigma não seja semelhante ao da gaivota que quis matar o caranguejo e acabou se matando". O corvo perguntou: “e como foi isso?” O chacal respondeu [...]. ${ }^{90}$

${ }^{89}$ IBN ALMUQAFFAc, Kalīla e Dimna. Tradução, organização, introdução e notas de Mamede Mustafa Jarouche. São Paulo: Biblioteca Martins Fontes, 2005, p.05.

${ }^{90}$ Ibid., p. 62. 
Ao longo de todo o livro, será possível perceber essa repetição, sendo poucas as vezes em que as fábulas não partem de um diálogo entre personagens contidos na narrativa-quadro. Uma exceção a esse procedimento ocorre quando o narrador principal - no caso, o sábio/filósofo Baydabā - insere uma fábula breve no contexto do prólogo-moldura, sem que isso parta necessariamente da interação de personagens, e que pode ser observado, por exemplo, em "O homem que fugia do lobo"

Aqui, vale uma contraposição: sabendo que o recurso apresentado não é necessariamente constitutivo do gênero, e que está muito mais ligado à tradição de narrativas do extremo Oriente - pois não se assemelha, por exemplo, à tradição helênica de fabulários, da qual citamos Esopo ${ }^{92}$ dentre inúmeros outros autores possíveis -, nos pomos a verificar a existência dele no Pañcatantra, no qual encontramos uma estratégia próxima, porém com suas peculiaridades; por sorte, a passagem recém-apontada se encontra também no compêndio indiano e, para demonstrar o que dizemos, apresentamo-la a seguir:

\footnotetext{
- Nessa situação - disse o chacal -, não se deve desesperar nem um pouco. Certamente, sem uma estratégia, aquela voraz não será castigada.

Com estratégia, a vitória sobre o inimigo torna-se tão certa que não se compara à vitória por meio de armas; o bom estrategista, mesmo de pequena estatura, não é sobrepujado pelos poderosos.

- Deste modo:

Por avidez excessiva, depois de comer muitos peixes grandes, pequenos e médios, uma certa garça foi morta no abraço de um caranguejo.

- Como foi isso? - ambos perguntaram.

O chacal contou [...].
}

Conforme é possível observar, na versão indiana o diálogo entre personagens é atravessado por trechos - ou çlokas - em que se apresentam razões teóricas que têm a finalidade de orientar os procedimentos. Muitas dessas razões encontram origem no Código de Leis de Manu (Manavadharmaçãstra). Esses entremeios corroboram o fabulário como um "tratado sobre a conduta” (nîtisâstra) e trazem apontamentos bastante importantes acerca do comportamento humano, porém, tornam o texto mais ritualizado e menos fluido. O livro de Kalīla e Dimna, não tendo de se basear ou se remeter ao mesmo código de leis, pega para si o que há de universal na história e trabalha de modo mais flexibilizado as noções e morais que pretende passar, obtendo, assim, efeitos mais dinâmicos e facilitando a leitura, eliminando as

\footnotetext{
${ }^{91}$ IBN ALMUQAFFA', Kalīla e Dimna. Tradução, organização, introdução e notas de Mamede Mustafa Jarouche. São Paulo: Biblioteca Martins Fontes, 2005, p. 47.

92 ESOPO, Esopo - Fábulas Completas. Tradução de Maria Celeste D. Dezotti. São Paulo: Cosac Naify, 2013.
} 
pausas/quebras que, embora fossem justificadas e apropriadas dentro de determinado contexto de produção, não se mantinham como necessárias.

Provavelmente, por conta dessa associação tão direta ao Código de Leis de Manu, o fabulário indiano não precisasse se afirmar ou se justificar como um importante manual de conhecimento; se afastando dessa referência, o livro de Kalīla e Dimna, então, precisaria se escorar em justificativas próprias para convencer o público de sua relevância, lançando mão, então, do prólogo, que foi estudado recentemente.

Nesse sentido, apontamos ainda outra diferença entre as obras: enquanto Pañcatantra significava Cinco tratados e, de fato - como já fora explicado no capítulo anterior - era apresentado no formato de cinco livros que, independentes entre si, traziam direcionamentos de condutas para temas variados, o Kalīla e Dimna se constitui em uma unidade que não segue a ordem indiana e se organiza de modo bastante diferenciado, próprio, chegando a apresentar narrativas únicas que não se desenvolvem num prólogo-moldura e, consequentemente, não se utilizam do esquema de estrutura-em-cadeia. Assim, enquanto a abertura de cada um dos cinco livros apresenta em uma frase, de forma abreviada, o tema do qual tratará (ou, em outras palavras, seu prólogo-moldura), sem a necessidade de se remeter ao anterior, o livro árabe assume a liberdade de estabelecer uma unidade a partir da relação entre Dabxalīm - rei da Índia - e Baydabā - “o mais eminente de seus filósofos”93 -, que, em mais uma ilustração podersaber, conduzem em diálogos cada uma das narrativas-quadro. Destarte, cada novo capítulo árabe se inicia com o soberano solicitando ao sábio um paradigma aplicável a uma situação que lhe provoca interesse, e assim vai se desenvolvendo a obra.

Apresentamos, a seguir, uma passagem para ilustrar o que fora dito:

Disse o rei ao filósofo: já ouvi o paradigma que aplicaste. Aplica-me agora, se considerares conveniente, a paradigma do homem cujos inimigos aumentaram e o cercaram por todos os lados, deixando-o à beira da aniquilação, mas ele então busca escapatória conciliando-se e pactuando com um de seus inimigos, salvando-se dos inimigos que temia e cumprindo o pacto. Informa-me, pois, como deve dar-se tal conciliação e como buscá-la. ${ }^{94}$

O capítulo se liga ao anterior, pois o rei vai pedindo a aplicação de paradigmas ao sábio e, conforme este lhe sacia a curiosidade, recebe, em seguida, um novo pedido. Essa estratégia, segundo nossa análise, também é associada a uma tentativa de nobilitar a obra: não são

${ }^{93}$ IBN ALMUQAFFAc, Kalīla e Dimna. Tradução, organização, introdução e notas de Mamede Mustafa Jarouche. São Paulo: Biblioteca Martins Fontes, 2005, p. 45.

94 Ibid., p. 213. 
quaisquer temas selecionados a esmo os que a compõem, mas sim os que suscitaram interesse em um rei, temas esses que um sábio - e não qualquer deles, mas o mais eminente - teria meios para abordar. Lembrando que, na obra indiana, o prólogo nos apresenta uma situação em que o rei solicita ao brâmane Viṣnuçarman um modo de tornar os filhos "rapidamente sábios inigualáveis na ciência política” ${ }^{95}$ sem, no entanto, definir mais especificamente quais seriam os temas que, em seu entendimento, comporiam esse saber de forma adequada, ou seja, deixando a cargo do brâmane essa eleição de conhecimentos. Aqui, o rei assume uma função mais ativa e, com isso, se efetua um redirecionamento: o sábio sempre está em relação ao rei, mas, no fabulário árabe, essa hierarquia ganha cores e contornos mais vivos. Era necessário explicitá-la, talvez? A pergunta se estabelece na mesma linha que tem sido delineada ao longo do estudo e, com mais elementos, pretendemos vislumbrar o que seja uma resposta satisfatória a ela.

Passaremos a apresentar adiante o modo como se estruturam os capítulos do livro, no que se refere às narrativas-quadro e suas subnarrativas.

\section{Narrativa-quadro}

\section{Diagrama do capítulo I - O leão e o touro}

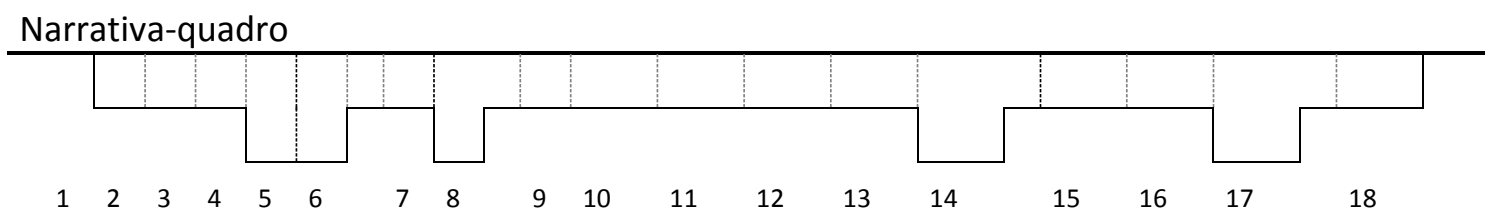

Figura 6

Capítulo que talvez mais se aproxime do correspondente nos tratados indianos, se relaciona, no caso, ao Livro I, “A desunião de amigos” no Pañcatantra. O rei pede ao sábio que

\footnotetext{
${ }^{95}$ ANÔNIMO. Pañcatantra: Fábulas Indianas - Livro I. Tradução de Maria da Graça Tesheimer; Maria Valíria Aderson de Mello Vargas; Marianne Erps Fleming. 2. Ed. São Paulo: Humanitas, 2004, p. 24.
} 
lhe dê "um paradigma aplicável a dois homens que muito se estimam entre os quais se interpõe um mentiroso traiçoeiro que os carrega à inimizade e ao ódio" ${ }^{96}$, e, a partir dessa narrativaquadro se desenvolvem outras dezoito narrativas, sendo que apenas uma delas não encontra similar no livro indiano. Nem por isso podemos dizer que se trata de uma cópia: o fabulário árabe toma a liberdade de deixar algumas fábulas para trás, se utilizando de apenas dois terços das fábulas indianas e, mesmo entre essas fábulas “escolhidas”, opera mudanças de ordem e até mesmo de personagens. Há fábulas em que os personagens são trocados e, em outras, eles até são os mesmos, mas têm diferentes ações atribuídas a eles, como na fábula “O leão o camelo, o lobo, o chacal e o corvo”, que encontra equivalência na indiana “O leão Madotkața” e, que, embora apresente a mesma configuração e presença de personagens, diferente dela, tem como principal articulador da artimanha que resultará na morte do camelo o corvo, e não o chacal, originalmente responsável no Pañcatantra. Um exemplo de fábula em que há a troca de personagens é “A raposa e o tambor”, que, embora se espelhe na indiana “O chacal e o tambor”, troca as espécies de animais que protagonizam as fábulas. Um aspecto interessante dessas alterações é que elas apontam para uma classe de animais que pode ser utilizada para representar determinadas características: um elefante jamais poderia ocupar o lugar de um chacal, mas animais que são representados como sagazes e ardilosos, em contrapartida, podem ocupar esses lugares sem prejuízo à moral que se pretende enunciar.

Vale dizer ainda algumas palavras a respeito desse capítulo, especificamente acerca da forma como se organizam as narrativas e subnarrativas: as dezoito fábulas que são inseridas na narrativa-quadro vão se desenvolvendo em dois níveis além do prólogo moldura, ou seja, além dele, há o nível primeiro, em que os animais da narrativa-quadro dialogam e, vez ou outra, personagens de suas fábulas tomam a voz para contar, também, outras fábulas. Conforme dito anteriormente, a estrutura se apresenta sempre da mesma forma, ou seja, cada fábula iniciada pode abrir espaço à inserção de outra ou se encerrar, em um movimento retroativo, nível a nível, para que se retorne à narrativa-quadro e ela possa ter seu desfecho.

${ }^{96}$ IBN ALMUQAFFAc, Kalīla e Dimna. Tradução, organização, introdução e notas de Mamede Mustafa Jarouche. São Paulo: Biblioteca Martins Fontes, 2005, p. 45. 


\section{Diagrama do capítulo II - Investigação acerca de Dimna}

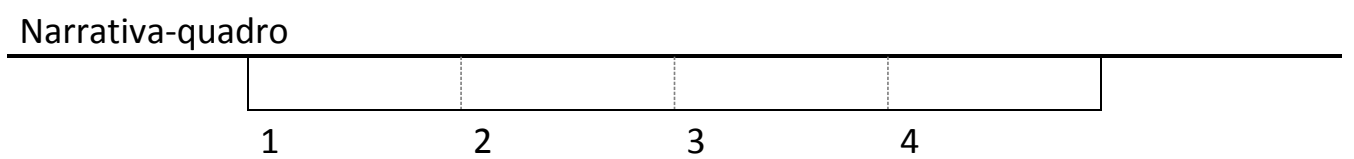

Figura 7

Continuação da primeira história, este capítulo é todo ele uma adição, provavelmente árabe, inexistente no fabulário indiano. É possível perceber diferenças bastante marcantes em sua estrutura e o acréscimo de personagens na dinâmica que não haviam sido apresentados anteriormente, além da exibição de uma espécie de julgamento que apresenta, de certa forma, uma organização de leis. Apesar das diferenças e da originalidade, o segundo capítulo também se utiliza de subnarrativas, quatro, a saber, de modo bastante simplificado, sem recorrer a outros níveis além do primeiro. A inserção deste capítulo dá ao primeiro um redirecionamento que reposiciona a moral inicial: se, inicialmente, no fabulário indiano, o touro Samjĩvaka havia sido morto por conta das artimanhas de Damanaka e, assim, o chacal operava uma aproximação bem-sucedida do leão, no primeiro capítulo de Kalīla e Dimna até chegamos imaginar que o mesmo ocorrerá, dado o seu fechamento, mas, com a adição deste capítulo, somos apresentados a uma investigação e punição, tanto a Dimna como a Kalīla, que fora cúmplice passivo de toda a ação primeira. Percebe-se que na reapresentação da obra ao mundo árabe não bastava a moral inicial apontar o dano que pode causar um invejoso e maledicente a um casal de amigos, era necessário também mostrar ao leitor que aquele que causasse o mal a outrem seria punido, e não bem-sucedido em seus desígnios, como acontece com Damanaka. 


\section{Diagrama do capítulo III - A pomba de colar}

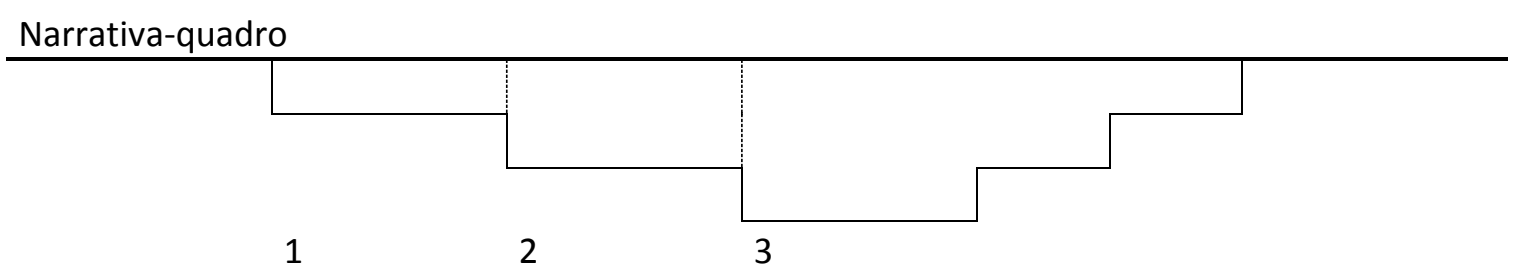

Figura 8

Com a estrutura narrativa mais elaborada, que tem, além da narrativa-quadro, três subníveis, este capítulo tem um paradigma/narrativa-quadro inicial: "sobre os amigos sinceros: como encetam suas primeiras relações, e como se comprazem uns com os outros”, e encontra semelhanças no segundo livro indiano, “A aquisição de amigos”.

A partir da narrativa-quadro se desenvolvem três subnarrativas, a saber: "O rato, o asceta e o hóspede”, “A mulher que trocou sésamo descascado por sésamo com casca”, “O caçador, o veado, o javali e o lobo”, sendo que todas essas fábulas encontram espelho no livro indiano, com uma observação: na fábula “A mulher que trocou sésamo descascado por sésamo com casca”, há uma diferença de desenlace e moral em relação à fábula indiana “A venda do gergelim descascado”, pois, enquanto a mulher indiana é desmascarada em sua artimanha e não consegue trocar seu gergelim por outro não descascado graças à observação atenta e desconfiada de um estudioso de um tratado de política indiano chamado Kãmandakĩyanĩtisãra, escrito por Kãmandaki, a mulher do fabulário árabe, embora atraia olhares desconfiados de sua ação, é bem sucedida em seu estratagema e consegue adquirir novo sésamo, mesmo que com casca, mas limpo. Talvez porque, novamente, quando se eliminam as referências aos tratados indianos, faz-se necessária uma adequação a essa nova condição, que chega a interferir no sucesso ou no fracasso dos intentos. 


\section{Diagrama do capítulo IV - Os corujões e os corvos}

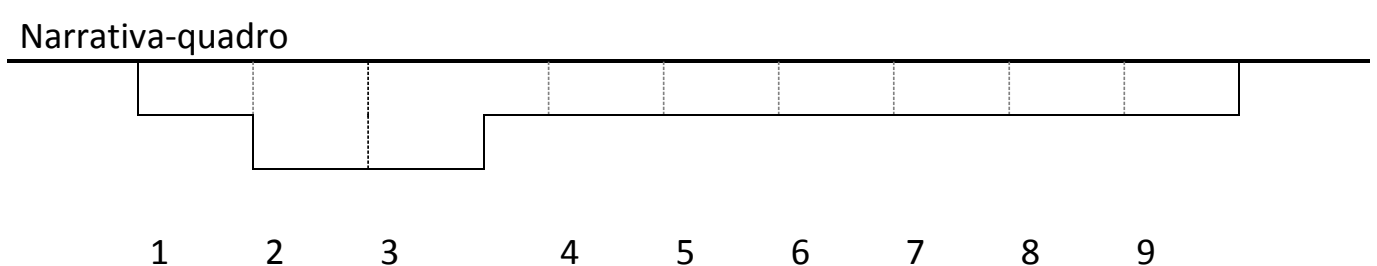

Figura 9

O quarto capítulo, que se inicia com o paradigma "de quem se ilude com o inimigo que afeta humildade”, apresenta uma estrutura narrativa mais simplificada, indo ao segundo nível apenas uma vez e mantendo a maioria das fábulas no primeiro nível. Encontramos as fontes para suas histórias tanto no Livro III, “A história dos corvos e das corujas” como no Livro IV do compêndio indiano, "A perda do bem conquistado”, dividindo-as da seguinte maneira: as fábulas “A origem da inimizade entre corvos e corujas”, “O leão e o rei dos elefantes”, “O pássaro medroso”, “A lebre e o gato devoto”, “O asceta, o cabrito e os trapaceiros”, “O asceta, a vaca leiteira, o ladrão e o demônio” e “A serpente envelhecida e o rei dos sapos” são encontradas, com sutis diferenças, no terceiro livro indiano, já as fábulas “O mercador velho, sua jovem esposa e o demônio”, “O carpinteiro, sua esposa e o amante dela” e “O asceta e a rata transformada em menina” encontram seus pares no Livro IV. 


\section{Diagrama do capítulo V - O macaco e o cágado}

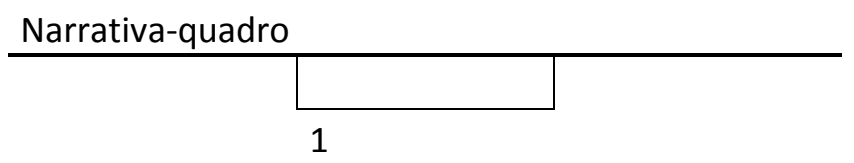

Figura 10

Este capítulo, de estrutura bem simplificada, encontra suas fontes do Livro IV do Pañcatantra, “A perda do bem conquistado”, sendo a narrativa-quadro de uma, indiana, origem da outra, árabe. A fábula que é contada dentro desta narrativa-quadro, ou seja, sua subnarrativa em primeiro nível é “O leão, o chacal e o burro sem orelhas nem coração”, similar à fábula II do quarto livro indiano, “A história de Karãlakesara”. Nela, uma passagem é especialmente interessante para o nosso estudo: o leão, debilitado, solicita ao chacal, seu súdito, que lhe traga um asno de quem possa arrancar as orelhas e o coração; embora o chacal seja - graças à sua sagacidade - bem-sucedido em sua tarefa, o leão perde o asno, não conseguindo agarrá-lo adequadamente e permitindo sua fuga, ao que se segue:

Disse o chacal ao leão; “o que fizeste? Se acaso soltaste o asno de propósito, por que me deixaste
esforçar-me para trazê-lo? Mas se porventura não o pudesse agarrar, isso é bem pior, pois
estaremos todos liquidados caso o nosso líder não esteja conseguindo agarrar um asno! O leão -
percebendo que se dissesse "soltei-o de propósito" estaria fazendo pouco caso do chacal e se
dissesse "não consegui agarrá-lo por fraqueza” perderia seu respeito - disse: "se conseguires
trazer o asno de novo até mim eu responderei à tua pergunta". ${ }^{97}$

Percebe-se uma importante nuance na construção do personagem leão: ao entender-se líder soberano graças - se não completamente, em grande parte - à sua força, não pode denunciar seu momento de fraqueza ao chacal, não podendo, consequentemente, ser franco em suas justificativas. Ao mesmo tempo, para que se mantenha líder também é necessário que respeite aquele que se posiciona como seu súdito, pois caso contrário será um rei solitário, o que se assemelha a não ser rei.

\footnotetext{
${ }^{97}$ IBN ALMUQAFFAc, Kalīla e Dimna. Tradução, organização, introdução e notas de Mamede Mustafa Jarouche. São Paulo: Biblioteca Martins Fontes, 2005, p. 171.
} 


\section{Diagrama do capítulo VI - O devoto e o mangusto}

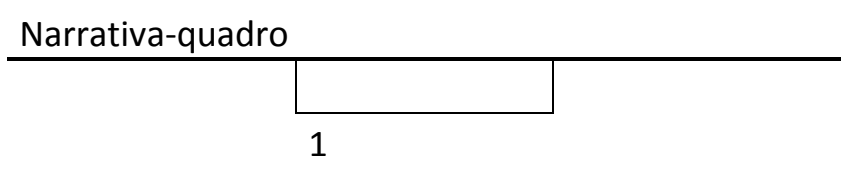

Figura 11

Neste capítulo, último em que ainda se verificam fontes indianas, o paradigma é o “do homem que age sem refletir nem se certificar”, e já identificamos aqui uma diferença entre as fábulas árabes e indianas: se na fábula em que encontramos similaridades, "O brâmane Devaçarman”, pertencente ao quinto livro indiano, grande parte das ações é conduzida por uma brâmani, aqui, o protagonista é do sexo masculino; a inversão dos papéis, contudo, não interfere na moralidade da fábula. Há a inserção de uma subnarrativa simples, mas o capítulo é, de modo geral, bem sucinto.

\section{Diagrama do capítulo VII - Iblād, Īrāhnt e Xārdam, rei da Índia}

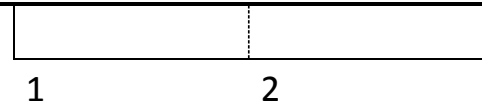

Figura 12

Aqui, um capítulo que, conforme já fora falado, não encontra espelho no Pañcatantra, assim como as fábulas que constituem as subnarrativas; segundo alguns autores afirmam, a origem da fábula seria budista e apresentaria um até então improvável ódio aos brâmanes. Ela contém, além da narrativa-quadro, duas outras fábulas que ficam no primeiro nível, de estrutura relativamente simples. 


\section{Diagrama do capítulo VIII - Mihrãyaz, o rei dos ratos}

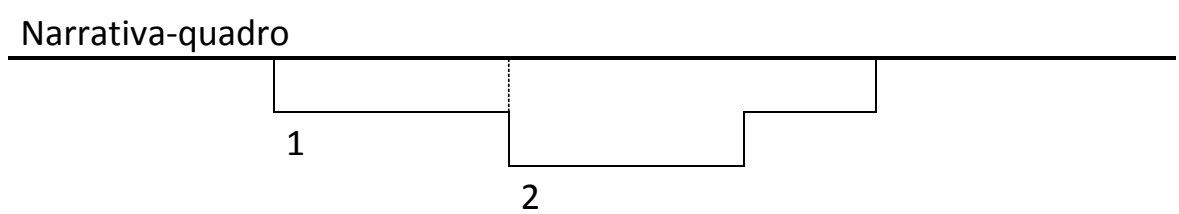

Figura 13

Não há dúvidas entre os estudiosos de que este capítulo, que não encontra similar em outro fabulário (com exceção da tradução siríaca do século VI, o que indica uma origem genuinamente pehlevi), não pertence originalmente ao que é entendido como escopo da cultura indiana ${ }^{98}$. Encontrado apenas em restritos manuscritos, difere muito do estilo dado ao fabulário árabe em estrutura e andamento geral. Apesar disso, mantém o esquema de narrativa-quadro e subnarrativas que, inclusive, chegam ao segundo nível, indicando que um personagem da narrativa-quadro contou uma fábula a alguém e que, no decorrer desta fábula, algum de seus personagens contou também uma fábula a outrem. Retrata a discórdia entre ratos e gatos para ilustrar como os ratos, por meio de uma artimanha, conseguiram se livrar de todos os gatos em certo contexto, para, assim, sinalizar aos homens que, se seres tão diminutos conseguem resolver suas contendas por meio de ardis, por que os homens, que segundo a fábula seriam entre as espécies os mais sábios, não poderiam também, se utilizando de ardis, resolver seus problemas?

\footnotetext{
${ }^{98}$ Este capítulo não consta na maioria dos manuscritos, o texto tampouco consta na tradução espanhola, é possível que se encontre na tradução siríaca antiga.
} 


\section{Diagrama do capítulo XV - O asceta e o hóspede}

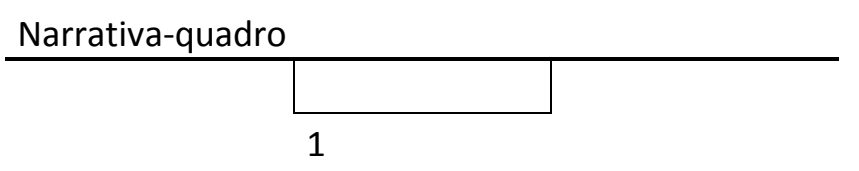

Figura 14

Capítulo que não encontra fonte em nenhum outro fabulário é, provavelmente, uma adição tardia, posterior ao próprio Ibn Almuqaffac ${ }^{c}$. Também de estrutura bastante simplificada, possui apenas uma subnarrativa relativamente rápida. Seu paradigma é o “de quem deixa de causar dano aos outros em virtude de danos que lhe sucederam”.

As demais narrativas não se encaixam nesse esquema, ou seja, o rei pede um paradigma ao sábio e este lhe conta uma fábula apenas (sem narrativa-quadro ou subnarrativas), e isso já é o suficiente para dar a entender aquilo que o rei pretende conhecer. São elas: “O gato e o rato" (capítulo 9), “O rei e a ave finza” (capítulo 10), “O leão e o chacal” (capítulo 11), “O peregrino e o ourives” (capítulo 12), “O filho do rei e seus companheiros” (capítulo 13), “A leoa e o animal Xachar” (capítulo 14).

\section{Das semelhanças - Prólogo para o estudo dos personagens}

A fim de ilustrar e confirmar os aspectos estudados no capítulo precedente, iniciamos aqui o estudo das personagens. Antes, porém, trataremos em pormenor das relações entre o Kalīla e Dimna e o Pañcatantra no que se refere a este aspecto, pois, a partir delas, poderemos realizar inferências mais precisas acerca das personagens e situações encontradas no fabulário.

É acertado ressaltar as semelhanças existentes entre as duas obras, muitas delas já devidamente apontadas tanto no capítulo anterior como neste, e necessário nos atermos tanto ao que concerne às semelhanças entre uma obra e outra como à utilização dos animais como personagens, antes de darmos início ao que foi intitulado como estudo de personagens e suas funções. 
No que diz respeito às semelhanças, pode-se dizer que, embora sejam muitas, não anulam os possíveis méritos do fabulário árabe em relação ao seu antecessor indiano, visto que, embora as narrativas principais condutoras de ambas as obras sejam as mesmas, além da maioria dos personagens e do uso que se dá a eles, é observada no livro de Kalīla e Dimna uma série de diferenças, adaptações e acréscimos em relação a sua precursora indiana.

Para elencarmos essas diferenças, adaptações e acréscimos, podemos partir da narrativa do Livro I do Pañcatantra, "A desunião de amigos", que se relaciona diretamente com o capítulo inicial de Kalīla e Dimna, O leão e o touro, cuja narrativa é complementada pelo capítulo II da mesma obra, Investigação acerca de Dimna.

Ocorre que o capítulo Investigação acerca de Dimna é, todo ele, um acréscimo em relação à obra indiana ${ }^{99}$, trazendo uma série de fatos, personagens e implicações não previstas no fabulário indiano. Além deste capítulo, muitas outras passagens do fabulário árabe diferem dos passos paralelos no Pañcatantra; encontram-se mesmo alterações na matéria narrativa de certas fábulas, e, além disso, é possível se deparar, como já demonstramos brevemente, com diferentes personagens ocupando outras posições - respeitando certos procedimentos que serão elencados.

Isso posto, passaremos agora a estudar os personagens sob a mesma perspectiva anteriormente apresentada; verificaremos quais são os personagens que ocupam, respectivamente, a posição de saber e de poder no fabulário árabe, quais as possíveis variações nesse esquema - e se a variação, ocorrendo, altera algum aspecto na fábula - e, por fim, quais as características observáveis na construção de cada um desses personagens-tipo.

\section{Poder - Leão}

Um personagem que surge na fábula inicial da obra, descrito como “vaidoso, prepotente, exclusivista e auto-suficiente”, mas que, mesmo possuidor dessas características que a princípio podem apresentar um peso negativo, ainda assim detém a posição de rei dos animais não questionada, devido a sua força e ao temor que provoca nos demais. É recorrente em fábulas de forte viés político em que são exploradas as questões relativas ao poder e sua legitimidade, além das artimanhas visando à aproximação do poder pelos outros animais, sua manutenção ou o

\footnotetext{
${ }^{99}$ Ou como sugere Mamede M. Jarouche no posfácio de O leão e o chacal mergulhador, o capítulo "Investigação acerca de Dimna” "talvez seja adição da tradução pehlevi, da qual não restaram versões; seja como for, na opinião do pesquisador, “o texto árabe foi visivelmente adaptado para se adequar às exigências da cultura muçulmana”.
} 
engodo pelos que almejam se aproveitar dele, já que a liderança do leão não envolve outra legitimidade que não a do medo e da força, ao contrário da liderança exercida pela pomba, por exemplo, no capítulo $\mathbf{O}$ colar da pomba, personagem que possui o respeito e a admiração das demais devido à firmeza de seu caráter.

A figura do leão representa o detentor do poder que toma decisões baseadas no impulso e nem sempre acertadas e, muitas vezes, se não ocorre a interferência de personagens dotados de sabedoria, acaba causando danos para si e para os demais. Além da impulsividade e da pouca ponderação antes da tomada de decisões, também é característica deste personagem a representação do poder e a facilidade com que pode ser enganado, ludibriado pelos demais ou mesmo convencido a tomar decisões conduzido pela persuasão de personagens outros com maior sabedoria, independentemente da finalidade para qual essa sabedoria é voltada.

De qualquer modo, apesar das características negativas que envolvem a figura do leão e do uso que sua personagem ganha nas fábulas, é inevitável averiguar que, devido à força dessa figura, apenas os dotados de sabedoria (passando ao largo do fim que almejam) se atrevem a tentar ludibriá-lo, pois, assim como diziam as máximas inseridas no fabulário, “(...) o leão, que é temido mesmo quando em repouso" ${ }^{100}$. Cabe apontar também que, embora a figura do leão seja, com frequência, observada e utilizada como metáfora de um poder pela força ou por uma predisposição inata, ele jamais é contestado; as outras personagens querem se aproximar dele e, consequentemente, do poder, porém, em nenhum momento sequer vislumbram a possibilidade de destroná-lo.

Conforme foi possível observar na construção do personagem-tipo leão no Pañcatantra, aqui também se repete um procedimento: o leão é aquele que ouve as fábulas, que recebe o conhecimento - independentemente do propósito com que esse conhecimento lhe é passado ele nunca conta a outrem uma fábula, não repassa o saber que por ventura possa apreender, enfim, não detém consigo essa possibilidade enquanto personagem da fábula.

O leão aparece em três fábulas no primeiro capítulo do livro, que já foram brevemente apresentadas, e agora serão melhor descritas.

Binkala, em capítulo I, narrativa-quadro, fábula “O leão e o touro”: Inicialmente descrito como “vaidoso, prepotente, exclusivista e auto-suficiente” ${ }^{101}$, se aterroriza pelo som

100 IBN ALMUQAFFA', Kal̄̄la e Dimna. Tradução, organização, introdução e notas de Mamede Mustafa Jarouche. São Paulo: Biblioteca Martins Fontes, 2005, p. 133.

101 Ibid. p. 47. 
de uma voz que não identifica, pois "nunca antes vira nem ouvira um touro" ${ }^{102}$, mas não diz nada e passa a não sair do lugar, para não levantar suspeitas em sua guarda. Kalīla e Dimna, dois chacais desconhecidos pelo leão, percebem a mudança de seu comportamento e Dimna vê a situação como a oportunidade que esperava para tentar se aproximar do rei. Tal como acontece na narrativa-quadro de Pañcatantra, “A desunião de amigos”, Dimna é bem-sucedido em seu intento e consegue se aproximar do animal desconhecido, que na verdade é o touro Xanzaba, que havia sido deixado para trás naquela região por homens que o consideraram moribundo. O leão, ao conhecer o touro, trata-o gentilmente e o convida para frequentar sua companhia, e os dois entabulam uma relação de amizade "até que o touro se tornou a companhia mais íntima e prestigiosa do leão"103. Embora seja bastante similar à narrativa-quadro do Livro I do Pañcatantra, “A desunião de amigos”, neste ponto a obra difere da indiana pois não alude em nenhum momento à possibilidade de que a relação entre leão e touro estivesse atrapalhando o soberano em seus desígnios para com seus súditos, e o único motivo que leva Dimna a recriminar essa relação é por se encontrar, novamente, afastado do poder. O chacal chega a alegar que “o leão está tão intensamente seduzido por Xanzaba que se expõe a ser por ele denegrido ou maculado»"104, mas essa é só uma justificativa da qual se utiliza para armar outro ardil, desta vez para separar leão e touro. O chacal é bem-sucedido em seu intento e, graças a ele, leão e touro não apenas rompem como Xanzaba é morto por Binkala, deixando espaço para a aproximação de Dimna. Conforme dito a princípio, o leão age precipitadamente e impulsionado pelo convencimento mal-intencionado de um personagem mais sagaz, que o leva a cometer um erro grave e matar mais do que um amigo, um inocente.

Ainda encontramos Binkala em Investigação acerca de Dimna, capítulo que é, inteiramente, adição árabe-islâmica, e no qual o leão, tomado pela culpa pela morte do touro e assombrado pela possibilidade de ter cometido uma grande injustiça, é convencido por sua mãe e por outros animais a iniciar o julgamento do chacal Dimna. Durante todo o capítulo o leão é orientado pelos outros animais para que não caia novamente nos argumentos ardilosos do chacal até que, ao término, graças a uma série de testemunhos, fica evidente a culpa de Dimna, que é deixado para morrer de sede e inanição.

102 IBN ALMUQAFFA', Kalīla e Dimna. Tradução, organização, introdução e notas de Mamede Mustafa Jarouche. São Paulo: Biblioteca Martins Fontes, 2005, p. 47.

${ }^{103}$ Ibid., p. 57.

${ }^{104}$ Ibid., p. 62. 
Leão, em capítulo I, fábula “O leão e as lebres”: os animais de uma floresta se mobilizam para saciar, dia após dia, a fome do leão e manter a sobrevivência da maioria, oferecendo cada um deles, diariamente, as suas vidas ao leão. Valendo-se de sua posição, o rei da floresta obtém constante vantagem em relação aos demais. O personagem é então enganado por uma lebre que não pretende para si este fim e que é apoiada pelas demais. Encontra espelho em “O leão Bhãsuraka”, fábula VIII do Livro I do Pañcatantra.

Leão, em capítulo 1, fábula “O leão, o camelo, o lobo, o chacal e o corvo”: Ao receber um camelo perdido, o leão lhe acolhe e promete proteção. Em uma situação adversa, aqueles que o servem, carnívoros, almejam a carne do camelo, que lhes é negada por conta da palavra inicial do leão. Apesar disso, ele é convencido pelo corvo a fazer parte de uma estratégia que lhe proverá alimentação e acarretará na morte do camelo, ao contrário do que havia prometido. Encontra espelho em “O leão Madotkata”, fábula XI do Livro I do Pañcatantra.

Como é possível observar, a quantidade de ocorrências desse personagem muda entre um e outro fabulário, pois o árabe deixa de lado algumas fábulas em que ele seria utilizado. Mantém-se, no entanto, o essencial: o exaltado uso do leão como alegoria do poder que subjuga todos os animais da floresta, tal como é exercida a soberania entre os humanos.

\section{Poder - Outros personagens}

\section{Os personagens masculinos humanos e suas ocorrências}

Assim como no fabulário indiano Pañcatantra, pudemos verificar uma série de fábulas em que os personagens não apenas eram humanos, homens, mas, além disso, reis. Isso nos levaria a perguntar, então, qual seria a finalidade desse tipo de construção; e, se seria possível inserir um rei humano nas fábulas, por que mais precisaríamos de um leão? Foi possível observar, no entanto, ao longo da leitura do livro de Kalīla e Dimna que, quando o narrador recorre a personagens masculinos humanos nas fábulas, eles normalmente não abrangem temas de natureza política, mesmo quando se trata de um rei homem. Na maioria das vezes o homem em questão observa ou sofre uma ação, de natureza corriqueira, da qual apreende uma moral; é o caso, por exemplo, do ocorrido na fábula "O eremita, o ladrão, a raposa e a mulher do sapateiro”, onde o asceta, após viver e presenciar uma série de situações onde verificava que os sofredores de intempéries muitas vezes as haviam atraído para si por conta própria, chega ao 
final da fábula alegando para o juiz que “(...) o ladrão não me roubou, a raposa não foi morta pelas cabras, a mulher devassa não foi morta pelo veneno e a mulher do sangrador não teve o nariz cortado pelo marido; fomos nós, isto sim, que fizemos essas coisas conosco mesmos”. ${ }^{105}$

Em geral, podemos afirmar acerca dos personagens masculinos humanos que eles costumam ser utilizados em fábulas diversas que tratem de temas cotidianos e questões de decoro, que costumam envolver a relação com a mulher, a aquisição de dinheiro e as diversas formas - lícitas ou não - de obtê-lo, e apenas na fábula "Iblād, Īrāĥt e Xārdam, rei da Índia” 106 podemos observar melhor a relação de um rei homem com o poder, mas, de qualquer forma, essa fábula rapidamente dá fim à questão do poder para em seguida voltar a trabalhar a relação do homem como marido, dessa vez de uma mulher virtuosa e dotada de inúmeras qualidades, dentre elas a inteligência, mas também caprichosa e voluntariosa.

Mantemos então a hipótese levantada quando da análise dos personagens do Pañcatantra: embora seja numerosa e, por isso, relevante, a ocorrência de humanos como reis nas fábulas não trata de relações de poder e política, e, quando muito, ilustra uma relação hierárquica, em que há personagens com posicionamento mais ou menos privilegiado, sem que isso exponha jogos políticos ou questões relativas a essa dinâmica. Embora em outro período histórico, a fábula enquanto gênero possivelmente ainda não se via autorizada a tratar de questões de política com personagens humanos, assim como sua antecessora indiana.

Corvo, Coruja, Elefante, Lebre, Rã e Rato - Também representados em algumas fábulas como reis, são personagens com pouquíssimas ocorrências nesse papel, o que dificulta a análise e comparação, aparecendo cerca de uma vez nessa posição ao longo de todo o livro. O que se pode observar em princípio é que esses animais são representados como reis apenas de suas respectivas espécies, ao contrário, novamente, do leão, que ocupa, assim como ocupava no fabulário indiano, o cargo mais alto da hierarquia entre todas as variedades de animais. Os reis da narrativa-quadro “Os corujões e os corvos”" ${ }^{107}$, corvo e coruja, são os que atuam em uma fábula de maior caracterização política, que ilustra a disputa entre duas espécies de animais distintas e na qual se mantêm, consequentemente, as mesmas regras de utilização do Pañcatantra, ou seja, ilustrando uma hierarquia em que espécies podem ter suas referidas lideranças, mas que, possivelmente, mesmo elas se submeteriam a leões, caso eles fossem

\footnotetext{
105 IBN ALMUQAFFA', Kalīla e Dimna. Tradução, organização, introdução e notas de Mamede Mustafa Jarouche. São Paulo: Biblioteca Martins Fontes, 2005, p. 60.

${ }^{106}$ Ibid., p. 177.

107 Ibid., p. 139.
} 
inseridos nesse esquema. Um elemento curioso em relação ao fabulário anteriormente estudado é o fato de que, neste fabulário árabe, as lebres da fábula "O lebrão e o rei dos elefantes” ${ }^{108}$ se organizam hierarquicamente de modo a ter um rei, no embate que se estabelece entre lebre e elefantes (novamente, em um mesmo procedimento que se utiliza de lideranças de cada espécie para ilustrar uma contenda entre elas). Na fábula indiana em que esta possivelmente se espelharia, “O grande elefante Caturdanta”, fábula I do Livro III, “A história dos corvos e das corujas”, as lebres se organizam em um grupo não submetido a uma hierarquia, e tomam as suas decisões em conjunto, em uma relação na qual todas podem opinar livremente.

\section{Saber - Chacal}

Esse personagem, assim como o leão, possui grande recorrência em fábulas de teor político mais evidenciado, sendo que na maioria delas representa o saber, a sagacidade e astúcia que provém dessa sabedoria. Não é necessariamente um personagem dotado de "bom-caráter”, sendo que pode utilizar seus conhecimentos tanto para aconselhar animais e recomendar estratégias que beneficiem outrem quanto também entabular estratégias para se aproximar do poder e se beneficiar dele.

De qualquer modo, é um personagem encontrado na maioria das fábulas que envolvem intrigas e relações de poderio em geral, como podemos observar no primeiro capítulo, O leão e o boi e no segundo, Investigação acerca de Dimna, que possuem os chacais Kalīla e Dimna, sendo que Dimna pretende se aproximar do rei por meio do uso de diversas estratégias e Kalīla, igualmente perspicaz, procura demover o companheiro de seus propósitos, por meio da argumentação retórica e da exposição de diversas fábulas e máximas, que são constantemente rebatidas por Dimna. No livro de Kalīla e Dimna, podemos observar que Dimna só não é bemsucedido em seu intento por conta da intervenção de terceiros (fato observado apenas no fabulário árabe), sendo que, caso dependesse apenas de sua capacidade de convencimento do leão (poder), seria exitoso em sua estratégia. É interessante destacar que o personagem, em certo momento da fábula, fala sobre sua condição a Dimna: “absolutamente não atentes para minha pequenez e debilidade, pois a coisas não se dão com força e grandeza. E quantas vezes

108 IBN ALMUQAFFAc, Kalīla e Dimna. Tradução, organização, introdução e notas de Mamede Mustafa Jarouche. São Paulo: Biblioteca Martins Fontes, 2005, p. 145. 
alguém fraco e pequeno atingiu, com sua astúcia, estratagemas e engenho, coisas que muitos fortes foram incapazes de atingir?”109

Além destas fábulas, lembramos que os chacais também aparecem outras vezes nos primeiros dois capítulos de Kalīla e Dimna, conforme se apresentará a seguir.

Chacal, em capítulo 1, fábula “ O corvo e a cobra naja”: o personagem é solicitado a aconselhar a personagem do corvo e elabora determinado estratagema contra a naja, recomendando ao corvo que procure "algo com o qual logres teu intento sem que sofras dano algum” ${ }^{110}$, numa fábula que resultará no paradigma de que “às vezes, a astúcia produz mais benefício do que a força” ${ }^{111}$, paradigma esse emblemático do personagem. Encontra espelho no fabulário indiano em Livro I, fábula VI - “O casal de corvos”

Chacal, em capítulo 1, fábula “O leão, o camelo, o lobo, o chacal e o corvo”: participa de um ardil que leva o leão a permitir a morte de um camelo para alimentar a ele e aos seus súditos. Aqui, notamos uma curiosa diferença entre a fábula indiana “O leão Madotkata”, do Livro I do Pañcatantra e a fábula árabe: na primeira o chacal era quem encabeçava o ardil e quem convencia o leão a trair sua palavra inicial, permitindo a morte do camelo. Aqui ele também marca presença de alguma forma na fábula, expondo sua sagacidade, mas quem lidera o ardil contra o camelo é o corvo.

Vale lembrar ainda que no Pañcatantra há outras ocorrências do personagem que aqui foram deixadas de lado ou trocadas por outros animais equivalentes, como no caso da fábula “O asceta e o ladrão”, em que o asceta topa em seu caminho com "duas cabras que lutavam dando trombadas e cujo sangue escorria; logo veio uma raposa que se pôs a lamber o sangue; distraída com isso, foi atingida e morta pelas cabras”112. Esta fábula possui uma equivalência no compêndio indiano, na fábula IV - “O monge mendicante Devaçarman”, porém, no lugar da raposa, quem sofre as consequências de se atentar apenas aos instintos é um chacal ${ }^{113}$.

\footnotetext{
109 IBN ALMUQAFFA', Kal̄̄la e Dimna. Tradução, organização, introdução e notas de Mamede Mustafa Jarouche. São Paulo: Biblioteca Martins Fontes, 2005, p. 62.

110 Ibid.

111 Ibid., p. 64.

112 Ibid., p. 58.

113 É necessário apontar que não são poucas as fábulas que utilizam a raposa de modo parecido com o chacal ao longo da história dos fabulários, inclusive no ocidente, reforçando a hipótese de ambos os animais estarem associados a um mesmo tipo. Utilizamos novamente como exemplo - entre uma série de possibilidades - $O$ livro das bestas, do filósofo catalão Raimundo Lúlio, do século XIII, em que, aliás, é possível verificar a ocorrência de uma série de fábulas similares às árabes. Nele, também fabulário de pano de fundo político, uma raposa é a principal responsável pelos ardis que são, em grande parte, associados aos jogos de poder.
} 
Assim como apontamos no capítulo anterior, no livro de Kalīla e Dimna se mantém a relação de proximidade entre leão e chacal, majoritariamente em fábulas em que são expostos os diversos contornos da política. É interessante observar inclusive a fábula do capítulo 11, “O leão e o chacal”, que nos remete ao fabulário que será estudado adiante, O leão e o chacal Mergulhador, e que trata de um chacal que, de comportamento absolutamente irrepreensível e de equivalente sapiência, mantém relação de proximidade com o leão e, por isso, atrai a inveja de outros ao redor.

\section{Saber - Outros personagens}

Corvo - costuma ser um personagem presente nas fábulas que envolvem o poder, e é uma figura, assim como o chacal, dotada de muita sabedoria e sagacidade, envolvido em diversos estratagemas com o objetivo de obter ou benefício para si próprio, ou para os seus. A figura do corvo também está ligada às fábulas de viés político pela força das relações que entabula, seja com amigos ou inimigos.

Além de aparecer na fábula já citada, onde, juntamente do lobo e o chacal convence o leão a fazer parte de um estratagema contra o camelo para não morrer de fome, nem precisar dar sua vida ou a de seus amigos para saciar a fome do leão, também é presente na fábula “A pomba de colar”, onde, indiferente à sua natureza, procura estabelecer laços de amizade com quem possa vir a lhe fazer bem futuramente, no caso o rato, de quem seria originalmente um predador. Anteriormente já havia aparecido como personagem na fábula onde busca pelo chacal para resolver uma contenta com a cobra naja por meio de uma artimanha, e adiante aparece novamente como personagem na fábula “Os corujões e os corvos”, onde se aproxima do inimigo, no caso as corujas, para poder elaborar uma estratégia para aniquilá-las, e quando inquirido pelo rei dos corvos sobre como suportou a companhia do inimigo, responde que “(...) o homem inteligente, quando acossado por algum perigo terrível que o faça temer a sinistra aniquilação de si mesmo e de seu povo, não terá alternativa senão suportar incômodos, não o afligindo a enorme paciência requerida, pois o que ele espera é chegar a um feliz resultado; não considerará desagradável tal esforço, nem julgará indigno submeter-se a quem é inferior a si até 
lograr seus objetivos, grato pelo bom termo a que chegou e satisfeito de seu próprio parecer e resignação". 114

Lebre - mais uma figura que, ao lado do leão, do chacal e do corvo, é recorrente em fábulas envolvendo o poder. Aparentemente um animal pequeno, frágil e inferior aos demais, a lebre aparece nas fábulas justamente como personagem que, independentemente de sua aparência, consegue sair-se bem das adversidades devido à sua sagacidade.

Sendo condenada à morte em uma das fábulas, a lebre consegue manipular e enganar o leão, levando-o a se atirar de uma cisterna, para assim atacar seu oponente, e adiante, vendo seu povo em perigo, cria um estratagema para afastar os elefantes de suas terras, no entanto, sem que possa usar a força, se utiliza sempre da inteligência. No caso, por ter sempre obstáculos relacionados a grande poder e força, como o leão e o elefante, é símbolo da possibilidade de o fraco vencer a força por meio da inteligência, principalmente nas relações políticas.

\section{Das hipóteses}

O estudo realizado neste trecho do trabalho apoiou-se principalmente na hipótese de que os personagens das fábulas são personagens tipificados e que contêm certos traços genéricos que possibilitam a sua utilização em determinadas situações, ao contrário do que aconteceria, por exemplo, em um romance ou em gêneros tradicionais da Literatura que seguem a famosa conceituação Aristotélica de ações decorrentes de caracteres (épica, tragédia etc.). Devido ao caráter moralizante do fabulário, as ações se sobrepõem aos personagens, e, por isso, sugere-se que não há neste gênero literário a necessidade de criação de personagens com traços característicos específicos, bastando às situações a existência de determinados tipos que possam ser adequados a elas, como, por exemplo, o leão, que é um tipo representativo de poder; cada tipo pode ser inserido em um determinado número de situações de forma que esta inserção mantenha os efeitos almejados pela fábula e, para ilustrar isso, utilizamos mais uma vez a figura do leão, que exerce nas narrativas papéis que não poderiam ser exercidos por outros animais, como o rato ou o chacal, por exemplo, pois, ao se realizar esta substituição, toda a estrutura narrativa e a moral correriam o risco de serem comprometidas.

\footnotetext{
114 IBN ALMUQAFFAc, Kalīla e Dimna. Tradução, organização, introdução e notas de Mamede Mustafa Jarouche. São Paulo: Biblioteca Martins Fontes, 2005, p. 159.
} 


\section{Capítulo III}

\section{Sobre $O$ leão e o chacal Mergulhador e o Livro do tigre e do raposo}

\section{Estabelecendo novas relações - dando continuidade à tradição}

Conforme fora anunciado nos capítulos iniciais desta dissertação, é chegado o momento de nos determos na análise e interpretação de duas obras bastante relevantes para a discussão dos pontos que foram apresentados até então, no estudo sobre o Pañcatantra e o livro de Kalīla e Dimna: o Livro do tigre e do raposo e O leão e o chacal Mergulhador. Tais obras, embora não tenham tido o mesmo alcance e repercussão ao longo do tempo e sejam até mesmo criticadas por alguns estudiosos e críticos literários como artificiais, incompletas e tachadas pejorativamente em comparação às outras duas mencionadas, se revelam importantes para os propósitos que este trabalho pretende alcançar, se não para corroborá-los, para, ao menos, desestabilizá-los e relativizá-los. O Livro do tigre e do raposo e O leão e o chacal Mergulhador se inserem na tradição dos fabulários, sendo produzidos, respectivamente, nos séculos IX d.C., XI d.C. e XII d.C., encontrando assim, outro contexto não apenas histórico, mas, sobretudo, político. Considerando que os fabulários, embora escritos sem um tempo definido ou um poder referido, se remetem metaforicamente a questões de natureza política, julga-se conveniente observar se a mudança dos tempos pode oferecer também uma mudança de abordagem, além da verificação, tal como realizado anteriormente, da permanência ou não de certos elementos estruturais apontados previamente, nos capítulos I e II. Iniciaremos a análise pelo Livro do tigre e do raposo, utilizando os mesmos critérios adotados até então, e em seguida (e da mesma forma), abordaremos O leão e o chacal Mergulhador, para, por fim, tecer relações entre estas e as anteriores e apresentar uma breve discussão sobre o que se arquitetará nas páginas que seguem.

\section{Livro do tigre e do raposo}

Ao nos determos na análise do Livro do tigre e do raposo e, principalmente, ao comparálo aos fabulários analisados anteriormente, salta aos olhos uma série de questões que nos forçam, necessariamente, a situá-lo quanto ao que foi dito antes acerca do que seriam os fabulários. A obra, datada do século IX d.C., mantém poucos pontos de aproximação com as 
anteriores, embora ainda possa, devido a alguns aspectos essenciais, ser considerada um fabulário. Trataremos dela a seguir, dos pontos em que se aproxima e se afasta, principalmente, do livro de Kalīla e Dimna e, na medida do possível, buscaremos nela argumentos para corroborar ou afastar hipóteses levantadas anteriormente no que diz respeito à construção de personagens e narrativas, além da natureza destas últimas.

Embora por algum tempo a autoria desta obra tenha sido contestada, atualmente é atribuída ao escriba Sahl Bin Hārūn, que trabalhava para Zubayda, esposa do califa Hārūn Arrašīd e, posteriormente, para o califa Alma'mūn, informações estas que nos são relevantes por tecerem uma relação bastante direta entre o autor do livro e a corte califal da época. Dela, se não podemos depreender verdades, podemos ao menos colocar em dúvida e relativizar o quanto a feitura do livro era ou não interessada e comprometida com a corte e alinhada às suas expectativas de leitura e, a partir disso, discutir quanta liberdade o autor teria para elaborar uma obra.

Contudo, se não podemos articular muito sobre a feitura da obra, podemos dizer sobre quem o autor pretendia como seu destinatário ${ }^{115}$ : quando declara, logo após os louvores a Deus, os propósitos da obra, revela tê-la feito para “o sábio letrado e o ajuizado sagaz”, qual seria, um "livro sobre decoro, retórica, epistolografia, guerras, artimanhas e provérbios, bem como sobre o sábio e o néscio [...]”. Nestas afirmações já podemos apontar o que seriam justificativas para uma obra que, se inserindo na tradição dos fabulários, deles diferiria em tantos aspectos. O Livro do tigre e do raposo, ao contrário do livro de Kalīla e Dimna, não se propunha a ser uma obra de ampla leitura da qual muitos pudessem tirar proveito, já que era dedicada e direcionada a sábios já detentores de vasto conhecimento e não a qualquer leitor. Se o livro de Kalīla e Dimna, de acordo com 'Abdullah Ibn Almuqaffac ${ }^{c}$, havia sido elaborado para reunir "sabedoria e diversão”, e, graças a isso, “os sábios elegeram-no por causa da sabedoria, e os néscios, por causa da diversão”, o mesmo não pretendia Sahl Bin Hārūn, que, embora tratasse dos néscios em sua obra, não os esperava como leitores. Tais dados explicariam o fato de a obra não oferecer o deleite entre suas principais proposições, e ser, principalmente em comparação à anterior, muito menos empenhada neste aspecto, do qual podemos dizer que ficou apenas a utilização dos animais antropomorfizados como personagens de sua narrativa, e a ficcionalidade - e

\footnotetext{
115 Tanto quanto se pode dizer a respeito disso, já que, embora o autor possa direcionar a sua obra a certo perfil de leitor e isso, por certo, influenciará em como e o que será escrito, ele pouco pode impedir que a recepção da obra seja feita por público bastante diverso do pretendido, o que pode ter bastante peso sobre as interpretações e leituras que serão realizadas.
} 
consequente atemporalidade - das questões tratadas. Tais elementos seriam, no entanto, essenciais para a caracterização do livro como um fabulário, sem invalidar, contudo, sua proximidade de um tratado político, num hibridismo aceitável e coerente com o que vem sendo estudado sobre o gênero em questão.

Além disso, também é possível, por meio da passagem “compus um livro conciso, abrangente e satisfatório”, justificar novamente a ausência do deleite como um propósito inicial, já que o autor pretendia dar conta de seus temas de forma precisa, sem se alongar além do necessário. Tais dados se refletem na leitura da obra, que abandona as subnarrativas tão presentes no livro de Kalīla e Dimna para dar lugar a uma única narrativa, planiforme e linear, na qual os espaços são preenchidos ou por meio de cartas ou de diálogos, pelos quais são expostas as ideias do que seriam bons modos de agir diante de uma série de contendas de natureza prioritariamente política e quais seriam, em contrapartida, os resultados de um proceder inadequado.

A respeito destes aspectos apontados, é possível dizer que, no que se refere à forma como se propõe, a obra em questão estaria muito mais próxima do fabulário indiano que de seu antecessor árabe, posto que também o Pañcatantra se propunha a ser - conforme analisado anteriormente - um compêndio conciso e apresentava uma estrutura narrativa bem mais simplificada que a do livro de Kalīla e Dimna. No entanto, enquanto a obra indiana se destinava a jovens que precisavam aprender muito em pouco tempo, esta da qual tratamos no momento já esperava de seu público certo grau de conhecimento, distanciando-se, neste ponto, tanto de Kalīla e Dimna como do Pañcatantra.

Outro aspecto presente no referido fabulário, que também difere das obras anteriormente estudadas, é a recorrente inserção de excertos de poesias tanto do período pré-islâmico como islâmico, atribuídas a poetas caros à tradição árabe, como é possível verificar na passagem a seguir, do poeta pré-islâmico Ibn Abī Așșalt ${ }^{116 .}$

Quem foge da morte certamente
a encontrará num descuido qualquer;
por mais que deseje viver, a alma, mesmo
a de vida longa, pela morte será alcançada;
seu condutor a conduzirá para a morte,
e, célere, seu guia para ela a empurrará:
quem não morre em dias ditosos morre de velho,

${ }^{116}$ HĀRŪN, Sahl Bin. O livro do tigre e do raposo. Tradução de Mamede Mustafa Jarouche. São Paulo: Amaral Gurgel Editorial, 2010, p. 36. 
pois a morte é uma taça da qual o homem provará.

E também na passagem adiante, do poeta islâmico Abū Alaswad Addu'alī (605-688 d.C. $)^{117}$ :

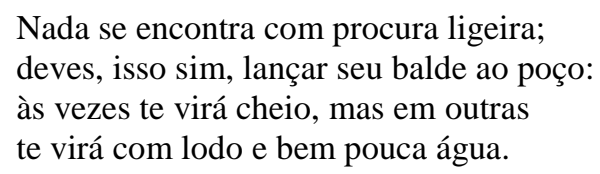

Embora tenha sido possível observar em cada um dos outros dois fabulários a inclusão de elementos que os arraigassem aos contextos históricos e culturais de seus períodos de produção e circulação, nenhum deles havia recorrido a essa utilização. É possível apontá-la tanto como uma estratégia para revestir a obra de valor literário como para reforçar um tom caracteristicamente árabe ao fabulário. Jarouche, na introdução Letrados em pele de raposo, sugere ainda que essa inserção de versos seja apenas um dos elementos dos quais o autor da obra se utiliza na tentativa de tornar o fabulário superior ao seu antecessor direto, Kalīla e Dimna, pois, segundo ele, “o Livro do tigre e do raposo também se produz como reação a ele [Kal̄̄la e Dimna], imitando-o no afã de superá-lo e substituí-lo”118.

Conforme já foi dito, a obra em questão desenvolve apenas uma narrativa principal, sem ser preenchida por narrativas secundárias ou por situações paralelas. A estrutura narrativa deste fabulário, bastante simplificada, trata de um raposo que, devido a um incidente, é levado a uma terra dominada por um tigre descrito como cruel e avaro. Tendo isso em vista e considerando sua parca constituição e situação diante daquele quadro, o raposo se associa a um lobo em um estratagema orquestrado por ele para tirar algum benefício das circunstâncias e manter-se em condições de vida agradáveis. Conservando por algum tempo o êxito neste quadro, uma série de outras circunstâncias - acarretadas pela imprudência do lobo - o levam a uma nova situação de risco, desta vez diante do próprio tigre, a quem precisa convencer ser útil para não sofrer as consequências pelos feitos do lobo e manter uma posição que lhe traga alguma comodidade, se não vantagem. É neste palco que se desenvolvem as situações e personagens que serão agora estudados.

${ }^{117}$ HĀRŪN, Sahl Bin. O livro do tigre e do raposo. Tradução de Mamede Mustafa Jarouche. São Paulo: Amaral Gurgel Editorial, 2010, p.39.

${ }^{118}$ Ibid., p.7. 


\section{Sobre os personagens - O leão, o tigre e as novas representações de poder}

De forma geral, a utilização de personagens no Livro do tigre e do raposo é bastante restrita, do qual podemos destacar três raposas, três tigres e um lobo: o raposo, personagem que inicia a narrativa, seu amigo, também um raposo, a mulher do personagem principal, o lobo com quem ele terá breves relações, um tigre detentor do poder local e outros dois tigres a serviço do primeiro. Também é possível observar a existência de uma série de conselheiros ou vizires do tigre, da qual três costumam se destacar, sem que, no entanto, possamos dizer a que espécie animal eles pertencem, já que não foram assim caracterizados na obra.

Destes personagens, nem sempre é possível dizer muito, tendo em vista que a narrativa utiliza alguns deles de forma bastante breve e acessória, mas tentaremos agora tecer algumas possíveis palavras sobre estes elementos tão peculiares e caros ao gênero que aqui estudamos.

Podemos apontar, logo de início, a diferença dos personagens que povoam esta obra para as previamente estudadas: se nas anteriores a principal narrativa seguia pelas ações de dois chacais, um touro e um leão, nesta, não encontramos nenhum deles. Não há chacais, há raposos, não há leão, há tigre. Aqui, sequer há um touro ou o que quer que seja para servir de mote para a situação, este elemento foi descartado sem que houvesse necessidade de buscar um outro que lhe repusesse a função. O que isso significa, considerando que a obra em questão se insere numa tradição literária? O que podemos supor, de antemão, é que isso poderia significar outras representações que não aquelas já apresentadas: se há alguma representação de saber, assim como de poder, estas possivelmente diferirão, em alguma (ou muita) medida, das delineadas nos fabulários Pañcatantra e Kalīla e Dimna.

Consideremos então a ocorrência dos personagens raposos: há três, mas falaremos agora sobre o raposo que dá título ao livro e seu amigo, pois a outra ocorrência deste animal se dará em uma personagem feminina que, além de aparecer pontualmente, não se relaciona aos aspectos estudados até então ${ }^{119}$. Vivendo em uma situação pacata há certo tempo, o raposo principal, Marzūq, de alcunha Abū Aș̣̣abāḥ, ao encontrar seu amigo raposo de longa data, Ṭāriq, de alcunha Abū Almuġallis, é alertado para deixar sua toca caso não queira terrível destino, pois ela havia sido construída em local inadequado, estando exposta a intempéries. Embora tenha uma aparição bastante abreviada no fabulário, tal amigo é responsável por

\footnotetext{
119 As personagens femininas nos fabulários orientais mereceriam um estudo dedicado exclusivamente a elas, tamanhas são as peculiaridades que envolvem as suas composições. Este trabalho, se sabendo restrito, prefere não abordá-las, para não resultar superficial.
} 
antever e aconselhar acerca de uma situação que, efetivada, dá início a todos os outros descaminhos de Marzūq até chegar na terra do tigre. É um personagem dotado de saber e precaução. Já Marzūq, embora sofra as consequências por não ter atendido o conselho do amigo, consegue chegar a outra terra e, precavido, procura saber como se estabelecer e se alimentar. Apesar da série de circunstâncias que se originam a partir deste desejo, é possível afirmar que o personagem, assim como seu amigo, era possuidor de um saber precavido e cauteloso e que, diferente dos chacais que lhe precederam na tradição, embora buscasse para si certo conforto e condições, não pretendia entabular relações com o poder, aliás, desejava desde sempre afastamento deste - não almejando proximidade sequer física, como apontaremos nas passagens adiante:

Conta-se que um raposo chamado Marzūq, cuja alcunha era Abū Așșabāḥ, foi residir num vale onde não tinha vizinho algum, e ali viveu largo tempo em boa situação, numa toca segura, despreocupado. ${ }^{120}$

E na seguinte, em que se dirige ao lobo:

- O rei te considerou lento naquilo para cuja execução te nomeou, pois atrasaste o combinado e desmentiste a tua sorte. Com esta carta, ele te incita, e, se acaso não emendares essa tua desatenção e corrigires esse tropeção, desgraças prorromperão e o caso ficará bem drástico. Açúcar com leite azedo acalma a cólera. ${ }^{121}$

Além da última, novamente endereçada ao lobo:

- Tu me consultaras no começo dessa questão toda, e eu não te poupei de conselhos, por temer que chegasses a semelhante resultado. Preveni-te contra os efeitos nefastos da queda, mas tu me desobedeceste e tomaste o mau caminho, até que se revelou, com a rebeldia, a tua máscara, tendo-se rompido [a viabilidade de] qualquer desculpa. ${ }^{122}$

Logo na passagem inicial podemos observar que não era objetivo do raposo aproximarse do poder, buscando aliás um lugar onde não tinha nem mesmo vizinhos, vivendo despreocupado com a vida até ser atravessado por uma situação que lhe forçou a ir para outras terras. Neste novo terreno, seus objetivos e artimanhas, ao saber das características do tigre, ao invés de visarem a uma aproximação, passaram a ser em busca de um local e condições com que pudesse se estabelecer bem e mesmo depois, quando o lobo passa a desobedecer ao acordo estabelecido com o tigre, os conselhos dados pelo raposo são de cautela, cuidado e mesmo de submissão, conselhos esses não ouvidos, como se pode observar na leitura da obra. Ao deparar com o tigre, novamente coloca em prática seus conhecimentos, mas é antes para salvar a própria vida e mantê-la dignamente que para quaisquer outros objetivos, pois, como se pode verificar

\footnotetext{
${ }^{120}$ HĀRŪN, Sahl Bin. O livro do tigre e do raposo. Tradução de Mamede Mustafa Jarouche. São Paulo: Amaral Gurgel Editorial, 2010, p. 31.

${ }^{121}$ Ibid., p. 44.

122 Ibid., p.71.
} 
na passagem "o tigre manietou as tropas inimigas, e levou como prisioneiros todos os soldados lobos, juntamente com o raposo, ordenando a seguir que fossem decapitados, e devoradas suas carnes” ${ }^{123}$, seu futuro, após a aliança com o lobo, não era calmo nem muito menos promissor.

Embora apresente bastante saber, conhecimento e astúcia, tal como os chacais anteriormente apresentados, o raposo não pretendia, de modo algum, se utilizar destas características para estabelecer nenhuma relação com o poder e se o faz, é antes por ser uma vítima de uma série de acontecimentos que por tê-los arquitetado. O raposo é quase que atropelado por situações em que precisa atinar rapidamente por algo que lhe dê condições de viver, tanto quando é levado de sua casa por uma inundação e chega a um lugar onde não pode obter alimento como também quando se vê prestes a morrer por ter estabelecido uma aliança que se mostrou infrutífera e por ter aconselhado em vão. Não é, de forma alguma, comparável aos chacais Damanaka e Dimna que, detentores de privilegiados saberes, sagacidade e astúcia, se utilizam deles para a construção de estratagemas que os aproximassem do poder, justamente por julgarem-se merecedores de tal benesse. O laço com o poder não é, em nenhum momento do livro, almejado pelo raposo, embora ele, ao longo do diálogo com o tigre, demonstre ter conhecimentos suficientes não apenas para aproximar-se do poder como para lidar com as suas vicissitudes.

Trataremos agora de dar cores aos outros personagens, nos detendo, neste momento, especificamente no tigre, dada a sua importância e relação com o poder, tão falado até então.

Após ter perdido sua morada e chegar a um novo lugar, ao procurar por condições de se alimentar o raposo é informado pelo lobo de que lá vivia “um tigre chamado Almuzaffar Bin Manșūr, que se impôs como rei desta ilha” ${ }^{124}$, trecho de que podemos destacar não apenas tratarse de um tigre e não de um leão o senhor daquelas terras, mas também que ele havia se imposto como rei, ou seja, que não era tranquila nem bem aceita, ou, melhor dizendo, unânime, esta atribuição de cargo ao tigre. Logo em seguida, o lobo continua a caracterizar o tigre com os seguintes dizeres "Sua crueldade, avareza e mesquinharia são na medida que já conheces das características dos tigres. Mesmo ao te falar agora não me sinto seguro, pois temo que ele surja e nos flagre»" ${ }^{125}$ e tal definição faz afirmações sobre o que seria próprio de todo tigre: a crueldade, a avareza e a mesquinharia. Tais características não tinham sido observadas até então

\footnotetext{
${ }^{123}$ HĀRŪN, Sahl Bin. O livro do tigre e do raposo. Tradução de Mamede Mustafa Jarouche. São Paulo: Amaral Gurgel Editorial, 2010, p. 73.

${ }^{124}$ Ibid. p. 37.

125 Ibid.
} 
na composição dos leões de Pañcatantra e Kalīla e Dimna, e muito menos relacionadas ao poder. É possível questioná-las, por virem da boca de um personagem que acaba de ser apresentado e que, por conta disso, pode revelar-se pouco confiável, portanto, são procuradas passagens que corroborem ou não tais atributos e, consequentemente, nos utilizamos novamente do trecho "o tigre manietou as tropas inimigas, e levou como prisioneiros todos os soldados lobos, juntamente com o raposo, ordenando a seguir que fossem decapitados, e devoradas suas carnes”126, que nos revela, se não um líder cruel, bastante impiedoso, por condenar todos aqueles que estavam ao lado de seu adversário a um destino mortal. Seria possível dizer ainda, pelo fato de o tigre aceitar que o lobo tomasse conta de certo distrito conquanto lhe enviasse considerável quinhão, que, embora não fosse mesquinho a ponto de negar o posto ao lobo, só o fizera por identificar uma situação nitidamente vantajosa que lhe asseguraria não somente o alimento, mas também o controle de terras relativamente distantes e que, por isso, ao permanecerem desguardadas, podiam ser tomadas por outrem. Além disso, o que se poderia dizer a respeito do tigre seria acerca de sua administração: ao perceber que havia sido ludibriado pelo lobo, passa a ameaçá-lo de acordo com os aconselhamentos de seus vizires e, ao perceber que o lobo ia ganhando forças e que a falta de uma atitude mais drástica poderia representar a desestabilização de seu reinado, vai até o seu inimigo para travar uma batalha e apronta contra ele uma armadilha:

[...] enquanto terçavam armas e lesões numerosas já haviam atingido os dois grupos, tropas que se mantinham escondidas, comandadas pelo rei, atacaram o lobo pela retaguarda, sendo Mukabir (o lobo) o primeiro a ser morto. ${ }^{127}$

Neste ponto, é adequado apontar que, ao contrário dos leões anteriores, o tigre não se lança justamente em uma batalha e, embora detivesse força física e poder, se utiliza de uma armadilha vil para obter vantagem em uma situação que, aparentemente, estava igualada: ambos os lados estavam lesados, e não era possível definir qual dali sairia vitorioso, caso não fosse a arquitetura de um ardil.

Tais informações nos levam a supor que o tigre em muito se distanciava dos leões, tanto pela forma como governava, como pelo modo que havia ascendido àquela posição, além dos meios que utilizava para mantê-la: não era um poder concedido, e sim tomado, e sua permanência se revelava ardilosa e vil, de tal forma que não podia ser comparada à dos leões, que, além de jamais terem tido a sua posição questionada, não eram do desagrado daqueles que

${ }^{126}$ HĀRŪN, Sahl Bin. O livro do tigre e do raposo. Tradução de Mamede Mustafa Jarouche. São Paulo: Amaral Gurgel Editorial, 2010, p. 73.

${ }^{127}$ Ibid. 
os rodeavam e, em situações de batalha, estando certos ou errados, arriscados a vencer ou morrer, haviam se disposto a lutar justamente e de igual para igual. Embora tanto os leões como o tigre estivessem sujeitos a tomar atitudes incorretas, sendo, por isso, acompanhados de conselheiros e vizires e, ainda assim, passíveis de erro como os cometidos pelos leões contra Samjjĩvaka e Xanzaba, os erros dos leões, além de não serem questionados e de não invalidarem suas autoridades, eram despropositais.

Destarte, é possível dizer que, assim como as figuras que aqui representam o saber e a astúcia diferem das detentoras destes atributos nos outros fabulários, também diferem os representantes do poder, e que esta diferença não se manifesta apenas na escolha dos personagens, mas também, e, talvez, justamente por isso, se manifeste através de suas condutas, chegando ao que havíamos sugerido previamente: o personagem é outro porque a alegorização que se deseja fazer é outra, não cabendo nas tipificações desenhadas outrora: sendo o leão detentor de um poder com características próprias, alegorizar outro tipo de poder, como o que é delineado neste fabulário, por meio da utilização de um leão, poderia resultar falha porque inverossímil dentro das expectativas e horizontes da recepção, o que poderia corromper todo o fabulário e, assim, não seriam alcançados seus objetivos.

É adequado dizer algumas palavras ainda acerca do personagem raposo, que tanto diferiu dos chacais até então estudados. Não havendo subnarrativas neste fabulário, também não há quem transmita fábulas a outrem, além da narrativa principal. Essa função, que consideramos didática, era até então exercida em um expressivo número de vezes pelos chacais, fato que inclusive se fazia constituinte de suas características como personagem-tipo. Oras, o raposo em nenhum momento tenta demover o lobo de suas decisões por meio deste recurso, se utilizando apenas do aconselhamento e, quando muito, de máximas ou provérbios, como "O homem inteligente deve ser habilidoso com o tempo tal como o nadador é habilidoso com a água corrente: [para salvares a vida] basta que te pendures na embarcação" 128 ou "quem se casa com a bela que pague o dote”129, ou ainda "açúcar em leite azedo acalma a cólera” ${ }^{130}$. Como já fora dito previamente, a ausência de subnarrativas se relaciona com as pretensões de construção e direcionamento da obra previamente anunciadas pelo autor, e nisso residiria mais uma diferença entre chacal e raposo, essas duas ilustrações de saber. Contudo, além das

\footnotetext{
${ }^{128}$ HĀRŪN, Sahl Bin. O livro do tigre e do raposo. Tradução de Mamede Mustafa Jarouche. São Paulo: Amaral Gurgel Editorial, 2010, p. 41.

${ }^{129}$ Ibid. p. 45.

${ }^{130}$ Ibid.
} 
demonstrações de conhecimento já mencionadas, o raposo ainda se vê em situação em que é desafiado a expor seu saber: diante da possibilidade de ser decapitado e ter suas carnes devoradas, sugere ao rei que ele pode se utilizar de seus conselhos para "ampliar a extensão de teu reino e o alcance da tua voz”131 e, diante dos vizires, se vê obrigado a convencê-los. Ocorre a partir daí uma importante passagem do livro, em que a narrativa é pausada e a obra passa a desenvolver, por meio da voz do raposo, conceitos sobre a condição humana, intelecto e saber (que são devidamente diferenciados). Tais conceitos não poderiam ser proferidos por outro personagem, novamente sob o risco de frustrar os objetivos da obra: o personagem do raposo foi construído ao longo do fabulário como portador de sabedoria e conhecimento, e, no momento em que é testado, se firma como detentor deste papel.

Sobre esta passagem do Livro do tigre e do raposo, ainda é adequado apontar que reafirma as relações entre poder e saber tão trabalhadas nesta dissertação, em dois níveis: ao mesmo tempo em que o tigre testa o saber do raposo para decidir se vai mantê-lo próximo ou não de si, verificamos neste fabulário de cunho político tão exaltado, que reserva grande parte de sua narrativa para ilustrar estratégias de abordagem no que se refere às questões do poder, uma passagem relevante dedicada à definições e conceituações acerca do saber, como se, de fato, estivesse demonstrando ao leitor a necessidade de aproximação do poder ao saber, tanto no nível da narrativa como na estruturação da obra; se, ao longo da narrativa, verificamos as vicissitudes dessa relação, que culminam em uma aproximação benéfica a ambos, poder e saber, a própria disposição do fabulário se organiza de modo a ressaltar que, em uma obra que se propõe a tratar dos liames do poder, não seria possível não dedicar nela relevante espaço ao saber, aproximando-os novamente.

Vale ainda dizer, a respeito do espaço que o compêndio dá ao saber - e que ocupa aproximadamente metade dele, fato que ressalta sua importância - que, curiosamente, ao chegarmos neste momento do fabulário, verificamos não apenas a mudança no formato já mencionada, em que a narrativa pausa e dá espaço a longas divagações conceituais, mas também a saída do plano dos animais antropomorfizados e a chegada ao campo do homem, do humano, literalmente, como se estivéssemos não mais em uma narrativa fábular, mas sim em um manual propriamente dito. A partir desse momento o livro não recorre mais aos personagens ou às situações como metafóricos, conforme podemos observar nas passagens a seguir:

\footnotetext{
${ }^{131}$ HĀRŪN, Sahl Bin. O livro do tigre e do raposo. Tradução de Mamede Mustafa Jarouche. São Paulo: Amaral Gurgel Editorial, 2010, p. 74.
} 
Decerto existe o homem cujo conhecimento em algumas coisas é certo, e incerto noutras. E entrementes medeiam muitos degraus, não sendo possível senão ao criador recensear aquilo em que o conhecimento humano é certo e aquilo em que é incerto ${ }^{132}$.

Ou ainda:

[...] qualquer homem paciente que só tem paciência por falta de opções e a quem a aflição nunca teve acesso não é paciente; qualquer benfeitor que faça uma benesse [em troca] de algum desejo ou por medo, e não por generosidade, só para receber gabo ou recompensa, não é benfeitor; qualquer comedido que não se abala com inquietações nem encontra refúgio contra a privação não é comedido. E assim, sucessivamente, não há lugar para louvar ou censurar qualquer homem dotado de alguma característica boa ou má da qual nunca possa livrar-se e passar à sua contrária $^{133}$.

É por meio das falas do raposo que recebemos esse conhecimento e não há, em nenhum momento, a inserção de alguma fábula ou de situação que ilustre a que ele se refere. O raposo mais uma vez difere em relação à conduta dos chacais estudados anteriormente e dispõe seu saber de forma enciclopédica.

\section{O leão e o chacal Mergulhador}

Elaborado entre a segunda metade do século XI d.C. e a primeira do século XII d.C., conforme é possível apontar, sobretudo, pelo encerramento ou colofão do livro, do qual se extrai a seguinte passagem:

Encerra-se aqui o Livro do leão e do [chacal] Mergulhador, graças a Deus e à sua benevolência. Terminou-se de copiá-lo na quinta-feira, aos vinte dias do mês de jumadá alahir do ano de novecentos e cinquenta \{grifo nosso\}. Baste-nos Deus, que é o nosso melhor responsável, e que suas preces e saudações sejam sobre nosso senhor Muhammad e os seus ${ }^{134}$.

Também desta passagem é possível extrair outras informações, mas, por enquanto, nos deteremos na sublinhada para dizer que, entre os acontecimentos deste período histórico, o esfacelamento das estruturas de cortes califais se sobressai; contudo, embora se possa dizer do período de feitura da obra, não é possível afirmar nada a respeito de sua autoria, posto que se perdeu no tempo, deixando-nos apenas o anonimato. É possível, no entanto, elaborar hipóteses que relacionem a autoria deste híbrido de fabulário e tratado político - que também pode ser considerado como “espelho de príncipe” ou "literatura sultanesca” - a alguém que tivesse não

\footnotetext{
${ }^{132}$ HĀRŪN, Sahl Bin. O livro do tigre e do raposo. Tradução de Mamede Mustafa Jarouche. São Paulo: Amaral Gurgel Editorial, 2010, p.81.

133 Ibid., p. 87.

134 ANÔNIMO. O leão e o chacal Mergulhador. Tradução de Mamede Mustafa Jarouche. São Paulo: Editora Globo, 2009, p. 191.
} 
apenas um elevado conhecimento da literatura corrente, mas também certo nível de relação com o poderio de sua época, tal como ocorrera com aqueles que compuseram o livro de Kalīla e Dimna e o Livro do tigre e do raposo, dado o grau de especificidade das relações e vicissitudes do poder ilustradas, tanto neste, como nos outros fabulários estudados. A respeito desta hipótese, Jarouche afirma:

Fica evidente que o autor, cujo nome não chegou a nossos dias, estava profundamente imerso na discussão política travada por todo o orbe islâmico, além de nutrido pela tradição literária e poética árabe, bem como por sua historiografia e pela distinção de gêneros que então se praticava na arte narrativa em árabe $[\ldots]^{135}$.

A obra em questão, situada na tradição das já estudadas, mantém os mesmos temas e enfoques outrora abordados, a saber: por meio de ações que se dão, majoritariamente, no reino animal, em uma floresta alegórica e num tempo indeterminado, desenvolvem-se situações de natureza predominantemente política em que personagens animais antropomorfizados precisam agir ou para se livrar (ou livrar alguém) de uma situação desvantajosa (ou até mesmo perigosa), ou para manter uma situação proveitosa e, na grande maioria das situações, o poder - ou por meio da força, ou por meio da astúcia - se coloca como força motriz dos acontecimentos. Neste fabulário, especificamente, é tratada com particular atenção a condição perigosa em que se coloca todo aquele que se aproxima do poder, independentemente da validade ou da virtude de seus propósitos; o chacal Mergulhador, principal personagem do fabulário, apesar de estabelecer um relacionamento com o leão apenas com o objetivo pontual de poupá-lo de uma situação de risco (que, caso viesse a se efetivar, colocaria, consequentemente, todos os seus súditos em condição igualmente ruim ou, quiçá, ainda pior), acaba por entabular com o poder laços que cedo ou tarde - e apesar de seus conhecimentos e conduta irrepreensível - se mostrarão altamente danosos a ele.

Contudo, é válido dizer algumas outras palavras sobre a sua composição, tendo em vista que a estrutura que se adotou para a feitura deste livro, assim como os demais, pode nos oferecer muito a respeito das particularidades e especificidades que aqui estudamos. Destarte, faz-se necessário dizer que, assim como as obras anteriores, podemos encontrar nesta um preâmbulo ou abertura na qual Deus - especificamente o deus islâmico - é louvado, como é possível evidenciar no trecho de abertura:

Louvores a Deus, a quem a língua é incapaz de descrever, tal como a razão é incapaz de lhe compreender a essência. Sejam as preces de Deus sobre quem nos exortou a adorar aquele que

\footnotetext{
135 ANÔNIMO. O leão e o chacal Mergulhador. Tradução de Mamede Mustafa Jarouche. São Paulo: Editora Globo, 2009, p. 195.
} 
nos dá a vida, e nos fez conhecer aquilo para o qual a nossa razão era insuficiente: Muhammad e os seus, e que a paz esteja com os adoradores que Deus elegeu ${ }^{136}$.

A religião, aliás, tem forte presença ao longo de toda a obra: ao entrarmos em contato com o chacal Mergulhador, sabemos que ele é um asceta e convertido ao islamismo, que dedica a maior parte de seu tempo às orações, à devoção e a penitências, sem demonstrar nenhum tipo de interesse na proximidade com o poder (tal como o raposo recentemente estudado). Conforme a obra avança, o chacal Mergulhador se vê em uma situação de risco da qual não sabe ao certo como se desvencilhar, justamente por não saber o que a originou, mas, ao invés de ter sua fé abalada, apenas a fortalece; interpelado por seu amigo sobre a confiança em Deus, chega a responder "Porque a confiança em Deus está no saber e na fé, e a determinação está na ação e no esforço. E não será a confiança em Deus, a qual está no coração, que impedirá o esforço na ação”" ${ }^{137}$. Diferentemente de obras anteriores, em que havia um espaço para a ação de brâmanes - fossem essas ações acertadas ou não -, neste fabulário já não há mais lugar para outra religião que não a muçulmana e, quando o há, é negativo: em apenas uma narrativa ${ }^{138}$ os brâmanes são representados, mas essa representação é bastante negativa, colocando-os como ansiosos pela morte de seu rei e responsáveis por um ardil para tentar matar um vizir.

Voltando ao preâmbulo, é possível depreender dele também o público que se buscava atingir com a tessitura das fábulas, que seriam rapazes e jovens, "pois suas almas buscam as narrativas mais valiosas, por meio das quais a sabedoria se estabelece em seu peito, adentrandolhes o coração, e o saber se fica em suas almas” ${ }^{139}$, em proximidade com o público almejado pelo fabulário Pañcatantra e que o meio adotado para atingir este público seria, tal como o "médico hábil que esconde o remédio em algum alimento apreciado pela alma”140, "palavras de sabedoria, que beneficiem quem as lê e procura”"141 introduzidas pelos sábios:

[...] nas notícias, mediante a fala de animais, e no decorrer de historietas, a fim de que ela se torne leve para o coração e conquiste a audição, e a adornaram com imagens elegantes e cores suaves a fim de que constitua em repouso para a alma dos sábios quando se entediam, e em desafogo para a mente dos eruditos quando se aborrecem, pois é pesado suportar a seriedade, cujo caminho é longínquo e árduo ${ }^{142}$.

\footnotetext{
${ }^{136}$ ANÔNIMO. O leão e o chacal Mergulhador. Tradução de Mamede Mustafa Jarouche. São Paulo: Editora Globo, 2009, p. 24.

${ }^{137}$ Ibid., p. 84.

${ }^{138}$ ANÔNIMO. O rei da Índia, seu vizir e os brâmane. In: O leão e o chacal Mergulhador. Tradução de Mamede Mustafa Jarouche. São Paulo: Editora Globo, 2009, p. 149-151.

139 Ibid., p. 24.

${ }^{140}$ Ibid.

${ }^{141}$ Ibid., p. 25.

${ }^{142}$ Ibid., p. 24.
} 
Assumindo as fábulas como uma espécie de artimanha na qual o modo como o que é transmitido é pensado para atingir uma finalidade que não o deleite, mas a utilidade, posto que, contudo, o deleite também não é, para o autor, por si um problema ou algo repreensível - ou mesmo um engodo -, tal como justifica em seguida:

Acaso não vês que Deus poderoso e exalçado fez da dor da fome e da vontade de comer um convite à alimentação, a qual é também motivo para a sobrevivência do indivíduo, e do prazer da cópula um motivo para a preservação da descendência? Em ambos os casos, a finalidade não é o prazer, mas sim a utilidade ${ }^{143}$.

Tal artimanha é utilizada, inclusive, como forma de argumentação e de construção do próprio preâmbulo, já numa tentativa de convencimento do leitor de que aquele método seria o mais adequado para a finalidade que se pretendia. Além disso, é interessante destacar a referência feita pelo autor, neste momento do fabulário, a Ibn Almuqaffac ${ }^{c}$, na passagem " $E$ eu considero belas as palavras de Ibn Almuqaffa ${ }^{c}$, que para descrever um de seus amigos disse 'Não censurava ninguém que talvez tivesse escusa para semelhante ação’”, 144 , um “autor” bemsucedido na tradição em que a obra se insere e não apenas isso, já que o livro O leão e o chacal Mergulhador se relaciona em diversos outros aspectos com o livro de Kalīla e Dimna, aspectos estes que serão trabalhados adiante. Por fim, vale dizer que também consta do preâmbulo a estrutura e organização em onze capítulos (embora nos deparemos, na leitura, com dezenove capítulos) $)^{145}$ e a pretensão de que a obra fosse "concisa e benéfica”, sendo estes objetivos recorrentes na composição de fabulários, como se pôde observar anteriormente.

Obra que se relaciona diretamente com os dois capítulos iniciais do livro de Kalīla e Dimna, a saber, O leão e o touro e Investigação acerca de Dimna, esse fabulário se utiliza, em uma espécie de retomada, do mesmo mote e da estrutura basilar do primeiro livro do Pañcatantra e dos já mencionados capítulos do livro de Kalīla e Dimna, além dos mesmos personagens, mas dá a toda essa estrutura um desenrolar bastante distinto, desde as características e motivações dos personagens, que se diferenciam por completo das existentes no livro de Kalīla e Dimna, até a solução do problema inicial - a existência de um ser aparentemente mais forte que amedronta o leão - e a função do personagem mote, inicialmente um touro, que nesse fabulário passa a ser um búfalo.

\footnotetext{
${ }^{143}$ ANÔNIMO. O rei da Índia, seu vizir e os brâmane. In: O leão e o chacal Mergulhador. Tradução de Mamede Mustafa Jarouche. São Paulo: Editora Globo, 2009, p. 24.

144 Ibid. p. 25.

${ }^{145}$ O fabulário, na verdade, se desenvolve ao longo de 19 capítulos, ao invés dos 11 anunciados no preâmbulo.
} 
A narrativa principal das fábulas "O leão e o touro" e "Investigação acerca de Dimna” trata de um touro que, por motivos diversos - e não propositais -, vem a se aproximar das terras das quais o leão é rei, e seu forte mugido passa a atormentar e até mesmo amedrontar o leão, “vaidoso, prepotente, exclusivista e auto-suficiente"146; essa fragilidade é observada por dois chacais, e, embora Kalīla tente demover Dimna de seu intento, o chacal arma uma artimanha para se aproximar do poder e assim poder usufruir das vantagens que ele proporciona. Graças à sua artimanha, o rei e o touro acabam se conhecendo e se tornando amigos muito próximos, o que acaba atrapalhando os planos do chacal de se aproximar do rei. Contrariado em suas intenções, posto que distante do leão graças à amizade dele com o touro, Dimna prepara então um ardil com o intento de acabar com esta relação, e esse ardil acarreta a morte do touro. Magoado e invadido pela sensação de ter cometido uma injustiça, o leão é avisado desta hipótese por sua mãe e, por conta disso, determina o início de uma investigação sobre as ações de Dimna, a qual, ao cabo do capítulo, acaba por incriminá-lo e desvendar todo o intento. Dimna é punido por suas ações, deixado à morte lenta, abandonado preso sem alimento.

Já no fabulário O leão e o chacal Mergulhador, um búfalo, assim como o touro, vem a se aproximar dos domínios do rei, um leão que desta vez é dotado de características nobres e descrito como "louvado por seus súditos, a quem conduzia conforme duas orientações às quais reunia firmeza: rigor sem violência e lhaneza sem fraqueza” ${ }^{147}$; assim como nas primeiras fábulas mencionadas, o leão se atemoriza pelo alto mugido do búfalo; porém, não reage dessa forma por desconhecê-lo: o leão sabe que o mugido vem de um búfalo que está demasiado próximo de seu reino e o que teme é justamente a possibilidade de não poder fazer frente àquele animal. O temor do leão é notado pelo chacal Mergulhador, que, embora seja tão sagaz quanto Dimna, possui objetivos e motivações totalmente diversas. Movido pelo interesse em fazer bem ao rei e, consequentemente, ao seu reinado, o chacal Mergulhador se aproxima do leão e, descobrindo o motivo de seus temores, arma um estratagema com o objetivo de dar cabo do problema do rei. O búfalo é morto antes mesmo de travar qualquer tipo de relação com o leão, e do sucesso da artimanha do chacal advém uma aproximação entre rei e sábio que é, em princípio, contrária aos desejos do chacal Mergulhador, mas que, ao se estabelecer, desperta a fúria dos que usufruíam antes dessa proximidade do leão. Por meio de uma série de estratégias realizadas por parte dos inimigos, o leão e o chacal se desentendem, sendo que o Mergulhador,

\footnotetext{
146 IBN ALMUQAFFAc, Kalīla e Dimna. Tradução, organização, introdução e notas de Mamede Mustafa Jarouche. São Paulo: Biblioteca Martins Fontes, 2005. p. 47.

147 ANÔNIMO. O leão e o chacal Mergulhador. Tradução de Mamede Mustafa Jarouche. São Paulo: Editora Globo, 2009, p. 27.
} 
acusado de uma série de atos que não cometera, é levado a se afastar do reinado e se retirar do convívio com os demais.

Como é possível se observar a partir do breve resumo feito das fábulas em questão, a estrutura inicial é a mesma em ambas, mas tanto o seu desenrolar como a caracterização e a utilização dos personagens é modificada, o que a princípio poderia constituir em uma averiguação da não veracidade de uma das hipóteses do trabalho, já que o poder estaria aqui representado, pelo mesmo personagem, mas de outra forma, da mesma forma que o saber, e isso consistiria em um não-submetimento de personagens a uma estrutura, como defendido anteriormente.

Ocorre que essa averiguação, embora tenha fundamento a princípio, não necessariamente chega a invalidar a hipótese inicial, pois se entende que a fábula, quando aborda determinadas situações, independentemente dos personagens e das características das quais eles são preenchidos, sempre trará o mesmo fim aos envolvidos. Nas fábulas em questão, não importam as finalidades ou motivações dos envolvidos, nem tampouco seu caráter: a figura que representa o poder e a figura que representa o saber travam uma relação na qual não se aproximam de fato, e, mesmo quando chegam a fazê-lo, tal proximidade é frágil e fugaz.

Consequentemente, de acordo com essa leitura e interpretação, a hipótese inicial se confirma, visto que em ambas as fábulas elementos genéricos são trabalhados dentro de uma estrutura que os molda e deles obtém resultados relacionados.

Antes de nos dedicarmos à análise dos personagens-tipo do fabulário e à estrutura narrativa proposta, assim como as suas peculiaridades e relações com as outras obras estudadas, vale apontar um aspecto que, tal como ocorrera em o Livro do tigre e do raposo, tem igualmente neste fabulário o seu espaço: embora com menor ocorrência, também em O leão e o chacal Mergulhador é possível observar a inserção de trechos atribuídos a poetas caros à tradição árabe, como os expostos a seguir:

\section{Nem todo o inteligente te dará o seu conselho, e nem todo aquele que dá conselho é inteligente; mas, se inteligência e conselho se unirem num só, então é direito desse que se lhe preste obediência ${ }^{148}$.}

E adiante:

\footnotetext{
148 ANÔNIMO. O leão e o chacal Mergulhador. Tradução de Mamede Mustafa Jarouche. São Paulo: Editora Globo, 2009, p. 71.
} 
As pessoas bem sabem que a liberalidade marcha

para o louvor, mas acaba com as propriedades ${ }^{149}$.

Oferecemos como hipóteses para essa estratégia as mesmas apresentadas outrora: preencher o compêndio de elementos que lhe atribuam características genuinamente árabes e, se não superar, ao menos equiparar-se ao livro de Kalīla e Dimna, inegável modelo de inspiração para este fabulário.

\section{A estrutura narrativa}

Ao nos determos no estudo da estrutura narrativa de O leão e o chacal Mergulhador, podemos perceber que se trata de um fabulário mais elaborado em relação ao seu antecessor direto, especialmente no que se refere ao uso de narrativas paralelas e subnarrativas. Aqui, novamente são utilizadas as estratégias já vistas em Pañcatantra e Kalīla e Dimna, que enriquecem a leitura e muitas vezes ilustram, em caráter antecipatório, o que virá a, irremediavelmente, ocorrer. Apesar disso, é notável que, neste fabulário, o uso de subnarrativas tem suas peculiaridades, que passaremos a apontar adiante.

De início, é notável o emprego mais simplificado das subnarrativas. Embora elas estejam presentes em bastante quantidade ao longo da obra, dificilmente ultrapassam o primeiro nível que vai além da narrativa-quadro, e, excetuando apenas um caso, entre as narrativas " $\mathrm{O}$ asceta resoluto e seus colegas ineptos" e "O passarinho e o rouxinol”, em que um dos personagens da primeira fábula passa a contar outra fábula, a segunda, até que se encerrem as duas e voltemos a acompanhar a narrativa-quadro, não é possível dizer que há narrativas circulares. Na maioria das ocorrências das subnarrativas, elas estão inseridas em diálogos em que um personagem aponta a similaridade da situação em questão a uma outra a qual se recorda e seu interlocutor, invariavelmente, lhe pergunta “E como isso se deu?”, ao que se sucede a narração, por vezes breve, que logo se encerra e retorna ao diálogo inicial. A partir disso, pode ocorrer a concordância ou a discordância com a similaridade aludida e, assim, os personagens podem dar continuidade, seja por meio do diálogo, seja por meio de uma nova subnarrativa que pode ser contada apenas por determinados personagens, vale dizer.

\footnotetext{
149 ANÔNIMO. O leão e o chacal Mergulhador. Tradução de Mamede Mustafa Jarouche. São Paulo: Editora Globo, 2009, p. 53.
} 
Há, no entanto, certo momento da obra em que as subnarrativas passam a assumir outra função: se, até o momento, em todos as obras estudadas, quando elas ocorriam, tinham como principais propósitos o convencimento ou a dissuasão de uma ação, em $O$ leão e o chacal Mergulhador aparece um novo uso, a corroboração. Assim, os personagens passam a contar uns aos outros sucessivas narrativas em que a repetição figura numa reafirmação constante do que fora dito inicialmente. A corroboração, nesse caso, justifica-se pelo contexto: utilizada especificamente - e unicamente - no momento em que os inimigos do chacal se unem e passam a versar sobre a melhor forma de conduzir sua incriminação sem que haja prejuízo para eles, é notável que nenhum deles pretende a dissuasão da artimanha, e sim, pelo contrário, que ela tenha pleno sucesso. Assim, passam a contar nove estórias ${ }^{150}$ nas quais é recorrente o tema da trapaça pela argumentação e uso da linguagem, tal como eles o farão adiante, ao serem interpelados pelo leão. Quando a narrativa se volta aos outros personagens, deixamos de observar esse recurso, e as subnarrativas voltam a ser utilizadas com os propósitos pelas quais são conhecidas.

Um outro aspecto relacionado à utilização de subnarrativas pode ser apontado neste fabulário: embora estejamos em contato com um conto-moldura em que há uma floresta alegórica, com personagens animais antropomorfizados, e, aparentemente, diante da presença de todos os elementos que compõem um fabulário, ao observarmos mais atentamente a inserção de subnarrativas na obra, verificamos que elas são, em um número considerável, não fábulas ou narrativas ficcionais, mas fatos extraídos de obras históricas ou de crônicas. Jarouche tece as seguintes considerações a respeito desse dado:

No período em que se produziu O leão e o chacal Mergulhador, ao contrário [do período em que
se produziu Kalīla e Dimna], a historiografia já estava bem sedimentada, o que proporcionou ao
seu autor uma grande quantidade de narrativas para escolher e introduzir na obra, e o gênero dos
tratados políticos se estabilizara enquanto tal ${ }^{151}$.

Isso se relaciona às diferenças históricas que contextualizaram cada produção: o livro de Kalīla e Dimna, ao contrário d'O leão e o chacal Mergulhador foi elaborado em um período histórico em que não estava, ainda segundo o autor, “sedimentada a historiografia nessa língua, e, portanto, inexistiam materiais por assim dizer 'profanos' que provessem de narrativas o

\footnotetext{
${ }^{150}$ São elas: "O príncipe que odiava beduínos”, “O endividado e as testemunhas”, “O casamento da filha do persa”, "Astúcia para evitar um casamento”, "O rei cruel e seu mestre sagaz”, “A disputa pela a ovelha”, "A salvaguarda e o copo d'água", "O cavaleiro e a salvaguarda” e "O paradeiro do inimigo e a salvaguarda".

${ }^{151}$ ANÔNIMO. O leão e o chacal Mergulhador. Tradução de Mamede Mustafa Jarouche. São Paulo: Editora Globo, 2009, p. 208.
} 
responsável pelo texto árabe”152. Essas diferenças acabam por interferir de modo bastante complexo nas obras: se o que tínhamos antes eram reproduções de tipos alegóricos que podiam representar, entre outras coisas, poder e saber em qualquer tempo e lugar, n’O leão e o chacal Mergulhador já verificamos uma movimentação diversa: ao nomear e situar especificamente pessoas e ocorrências que podem ser comprovadas em registros historiográficos, a universalização antes recorrente passa a dar lugar a uma exemplificação particularizada. Não à toa a obra em questão passa a ser denominada não apenas como um fabulário político - que,

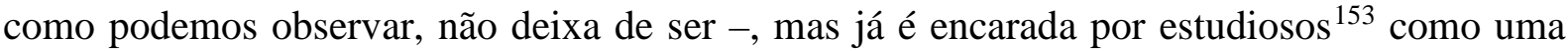
fusão entre fabulário e tratado político.

\section{Os personagens}

Assim como o Livro do tigre e do raposo, este fabulário dispõe de um número bem mais enxuto de personagens, dentre os quais podemos destacar o leão, o chacal, seu amigo, seus inimigos e o búfalo - que, conforme já dissemos, só tem função enquanto mote, não chegando a apresentar características outrora observáveis em touros, por exemplo. Há, nas subnarrativas, uma série de referências a personagens históricos que, como exemplos mais particulares, não seriam adequadamente estudados como tipo e, mesmo entre as subnarrativas ficcionais, não são observados tipos recorrentes. Adiante, passaremos então a analisar os personagens que se destacam dentro da proposta inicial já explicitada.

\section{Poder - Leão}

O leão representado neste fabulário difere bastante dos personagens-tipo associados ao poder até então estudados, não encontrando par nem entre os leões apresentados em Pañcatantra e Kalīla e Dimna, nem muito menos no tigre de o Livro do tigre e do raposo. Enquanto os dois primeiros leões - principais nos referidos fabulários - eram personagens dotados de muita força e conscientes dela, porém, de atos nem sempre acertados e até mesmo descritos como simplórios ou vaidosos e prepotentes, e o tigre era descrito como cruel, avaro e

\footnotetext{
${ }^{152}$ ANÔNIMO. O leão e o chacal Mergulhador. Tradução de Mamede Mustafa Jarouche. São Paulo: Editora Globo, 2009, p. 208.

${ }^{153}$ A moderna crítica árabe adotando uma terminologia ocidental passa a empregar este termo ou também "literatura sultanesca".
} 
mesquinho, o leão desta obra recebe para si um capítulo todo dedicado às suas (muitas) qualidades: é descrito como "louvado por seus súditos”"154 graças à condução de seu reinado, que reunia "rigor sem violência e lhaneza sem fraqueza" ${ }^{155}$. Proposto como um rei de conduta irrepreensível, recebia tanto respeito como amor de seus subordinados, agindo com reconhecida justiça e distinta autoridade.

Curiosamente, após sermos apresentados a esse leão, modelo de uma soberania justa e adequada e, que, de fato, se comporta de modo exemplar ao longo de toda a obra - mesmo quando é vítima de um ardil e levado a cometer um erro de julgamento -, entramos em contato com o segundo capítulo, Capítulo sobre o que se impõe aos súditos quanto ao aconselhamento do rei, e com o que o amigo do Mergulhador tem a dizer não sobre este leão em especial, mas sobre o soberano, sobre aquele (seja lá quem for) que está no papel de detentor do poder. A visão apontada por ele em muito difere do personagem que nos havia sido apresentado: para o amigo do chacal (amigo esse ao qual o livro não atribui nenhuma espécie animal), o soberano é alguém de quem não é benéfica a aproximação, conforme a passagem a seguir evidencia:

Não te leve a aproximar-te dos reis o amor da procura excessiva por ruínas evanescentes, pois o muito que recebes na escassez é o mesmo do qual na abundância desdenhas, preferindo arrostar perigos e sofrer fadigas. ${ }^{156}$

Da mesma forma, adiante, a admoestação:

Disseram: “Acautela-te da colaboração com o soberano, pois, quando ele recorre a ti, é fadiga, e, quando te evita, é humilhação”. E já se disse: “O que de melhor há na altanaria é o pairar acima dos defeitos alheios, e o abandonar a submissão quando ela excede o aceitável”. ${ }^{157}$

Ao longo do terceiro capítulo, Capítulo sobre qual é a necessidade do dotado de mérito em lisonjear os colaboradores do rei, ainda entramos em contato com mais falas e máximas a respeito dos reis e é adequado apontar que a maioria delas - assim como nos fabulários anteriores - não defende a aproximação do soberano por quem quer que seja, independentemente de suas motivações. Segundo elas, aquele que se associa aos soberanos se coloca em situação de risco e mais cedo ou mais tarde será prejudicado, e, quanto a isso, é válido destacar ainda a seguinte passagem:

154 ANÔNIMO. O leão e o chacal Mergulhador. Tradução de Mamede Mustafa Jarouche. São Paulo: Editora Globo, 2009, p. 27.

155 Ibid.

156 Ibid., p. 32.

157 Ibid. 
Alguém disse: “Zela por fazer minguar o número dos inimigos do soberano com o qual privas: o inimigo do soberano é mais perigoso para ti do que para ele, pois o ataca trapaceando contra os mais íntimos de seus atendentes e servidores, cujos defeitos ele recenseia e cujos rastros persegue, atiçando suspeitas no rei em relação a eles”. ${ }^{158}$

E a recomendação:

Disse certo sábio: "Se acaso notares que o soberano faz de ti um irmão, faze dele um senhor; e se ele intensificar o tratamento de irmão, intensifica tu o tratamento de senhor”. E disse outro: "Quem acompanha o soberano é como quem monta o leão, pois quem o vê em tal montaria o teme, embora ele próprio esteja dela mais temeroso”. 159

Vale dizer que grande parte das falas do amigo do chacal sobre os reis se remetem aos ditos de outrem, como se pôde verificar nas passagens anteriores; o amigo do Mergulhador, dessa forma, tem sua opinião revestida de valor, pois, não se trata de apenas uma constatação sua, mas de outros, inclusive sábios, com os quais ele concorda.

De qualquer forma, há uma aparente dissonância: se, por um lado, somos apresentados a um rei que é tido como admirável sob os mais variados aspectos, inclusive aos olhos de seus súditos, por outro, há o papel que o soberano ocupa, que afasta e traz consigo uma série de aspectos negativos. O leão apresentado nesta obra destoaria então, em uma leitura inicial, não apenas dos demais detentores do poder estudados até então, mas também do que se se diz daquele que ocupa o papel de soberano de modo geral. Ocorre que, à medida em que damos continuidade à leitura do fabulário, podemos verificar que as características positivas que revestem este leão não impedem o Mergulhador de, ao estabelecer uma aproximação, sofrer as consequências negativas que abatem a todos aqueles que arriscam essa aliança; não importa necessariamente de que forma o poder é conduzido, mas sim o fato de que ele é altamente perigoso para aqueles com quem entabula relações.

A diferença da descrição e da conduta do personagem, além de tudo que já fora dito, não impede uma repetição: este leão também é vítima de um ardil, assim como todos os detentores do poder descritos anteriormente. Ao demandar a aproximação do chacal Mergulhador, desperta a inveja de parte do seu séquito e é enganado, levado a acreditar que o chacal não é digno de sua confiança.

N’O leão e o chacal Mergulhador, outro aspecto se repete: novamente o leão não detém narrativas. Embora o leão deste fabulário seja, em muitas medidas, diferente do que havia sido designado como detentor do poder, e tenha lá sua parcela de conhecimento, ainda assim não

${ }^{158}$ ANÔNIMO. O leão e o chacal Mergulhador. Tradução de Mamede Mustafa Jarouche. São Paulo: Editora Globo, 2009, p. 40.

${ }^{159}$ Ibid., p. 42. 
conta, em nenhum momento da obra, uma fábula. É interessante inclusive destacar a passagem adiante, em que leão e Mergulhador dialogam:

\begin{abstract}
Disse-lhe o leão: "Não me agrada usar de artimanha tendo eu tanta força de ataque e física. São os animais fracos que recorrem à astúcia e artimanha”. Disse-lhe o Mergulhador: "Ó rei! Os sapientes já disseram: São quatro as coisas mais perniciosas ao homem: exagerar na comida por confiar na saúde, desperdiçar ações por confiar no destino, desprezar a artimanha por acreditar na força, e abandonar o arrojo por confiar na sorte." 160
\end{abstract}

Nesta passagem podemos observar que o leão se posiciona contrário ao uso de ardis, por se saber possuidor de força; para ele, o ardil é a arma dos fracos. De certa forma, é possível extrapolar esse trecho para a compreensão de que reis não precisam convencer alguém do que quer que seja, justamente pelo fato de que se impõem pela força e pelo poder que detêm. Considerando que o próprio autor do fabulário entende e apresenta as fábulas como artimanhas, assemelhando-as à ação do médico hábil que, como podemos observar na passagem a seguir:

[...] esconde o remédio em algum alimento apreciado pela alma, e assim também ludibriam a alma dos rapazes e dos jovens a fim de que se inclinem à aquisição de fábulas, pois suas almas buscam as narrativas mais valiosas, por meio das quais a sabedoria se estabelece em seu peito, adentrando-lhes o coração, e o saber se fixa em suas almas $[. . .]^{161}$

É compreensível que, seguindo este raciocínio, o leão não seja um contador de fábulas, não seja um narrador. Não caberia ao papel do poder a utilização de estratégias de convencimento, posto que: quem tem força não se utiliza de artimanhas $\wedge$ fábulas são artimanhas $\rightarrow$ quem tem força, portanto, não se utiliza de fábulas.

Encerradas as considerações a respeito desse personagem e não havendo no livro outra representação significativa do poder, passamos agora à análise do personagem-tipo chacal, detentor do saber.

\title{
Saber - Chacal
}

O Mergulhador, assim como o leão deste fabulário, difere em muito dos outros chacais estudados no presente trabalho, sobretudo por conta de dois aspectos: seu apego à religiosidade e seus propósitos, as motivações que o levam a se aproximar do rei. Ao perceber que o rei estava agindo de forma diferente, o chacal vai, assim como os antecessores, Damanaka e Dimna, procurar aconselhamento com um amigo; embora ouça de seu amigo conselhos muito próximos daqueles ouvidos pelos outros chacais, não é demovido de sua intenção. Porém, é nesse

${ }^{160}$ ANÔNIMO. O leão e o chacal Mergulhador. Tradução de Mamede Mustafa Jarouche. São Paulo: Editora Globo, 2009, p. 208.

161 Ibid., 82. 
momento em que já se delineiam as diferenças: Damanaka e Dimna creem que a aproximação do rei e, necessariamente, do poder, lhes é de direito, e reparadora de uma injustiça. Ambos se consideram merecedores de tal posição e veem na situação posta uma chance de ascensão. O Mergulhador em nenhum momento almeja essa proximidade - o que poderia assemelhá-lo ao raposo -, e pretende, desde o início, que seu abeiramento do leão seja pontual, apenas com o objetivo de livrar a todos de um risco. É possível verificar nas leituras do Pañcatantra e do livro de Kalīla e Dimna que tanto Damanaka como Dimna conseguiam perceber o risco ao qual os leões expunham seus subordinados ao não apresentar reação contra o barulho que lhes causava temor, mas, nos dois casos, o que se sobrepõe à necessidade de fazer um bem a todos é a suposição de um merecido reconhecimento e valorização individual. Já em O leão e o chacal Mergulhador, em nenhum momento o chacal almeja qualquer forma de reconhecimento ou premiação terrena, ao longo de todo o seu diálogo com seu amigo e mesmo depois, quando coloca em prática seu aconselhamento ao rei, o que ele pretende é o bem de todos, a manutenção da harmonia do reino. Destacamos as passagens a seguir para dar um vislumbre de qual seria a posição do Mergulhador:

[...] impõe-se aos súditos que se esforcem para o bem do rei e seu auxílio em tudo quanto possam no que tange a bons pareceres e capacidade, tal como deve o rei despender por seus súditos aquilo que lhe melhora a situação relativamente à administração e aos mantimentos, pois no bom estado do rei está o bom estado de seu reino, e no bom estado de seu reino está o bom estado do conjunto, do qual o aconselhador é parte, sendo prejudicado pelo que prejudica esse conjunto e beneficiado pelo que o beneficia. Os sábios já disseram: trai a si mesmo quem poupa seus conselhos ao rei, é avaro em seus bons pareceres para com o amigo e esconde do médico sua doença. ${ }^{162}$

[...] colocar a vida do rei em risco não é colocar apenas uma vida em risco, mas sim as vidas de todos os membros do reino; assim, estarei com a minha vida em perigo nos dois casos, com certeza, se por ventura eu dispuser de minha vida para proteger incontáveis vidas, quão grandiosa será minha recompensa se eu for eliminado, e quão grande serão minha sorte e meu orgulho se acaso eu triunfar! ${ }^{163}$

É notável que o chacal almeja o bem do reino e que, dispondo sua vida para esse fim, também expõe outro aspecto peculiar da construção deste personagem: seu ascetismo e apego ao islamismo, a sua crença em uma recompensa que não pertence ao mundo terreno, ao mundano. Durante toda a leitura do fabulário, o chacal nos coloca em contato com a sua fé inabalável, a qual já fora mencionada, e sua conduta é associada a ela. Não há como distanciar saber e religiosidade na fala do chacal, o que exalta, consequentemente, o tom religioso do fabulário e nos coloca a seguinte questão: seria a religiosidade tão presente na construção deste

162 ANÔNIMO. O leão e o chacal Mergulhador. Tradução de Mamede Mustafa Jarouche. São Paulo: Editora Globo, 2009, p. 30.

${ }^{163}$ Ibid., p. 62. 
personagem a definidora também de seu comportamento? Não podia agir o Mergulhador de forma diferente da que age, pois, caso contrário, isso afrontaria os preceitos da sua crença? Aparentemente, e com as ferramentas de análise de que dispomos, respondemos positivamente a essas questões.

Contrariando sua vontade, o chacal acaba por estabelecer relativa e relutante proximidade com o rei, e, inevitavelmente, paga o preço - que naturalmente pagam sempre os mais fracos - por essa aliança, se assemelhando, curiosamente, a outros personagens: Samjĩvaka e a Xanzaba, os touros de Pañcatantra e do livro de Kalīla e Dimna, respectivamente; por ser convocado a estar com o leão, “alguns íntimos do rei passaram a invejar o Mergulhador, e combinaram urdir-lhe uma armadilha” ${ }^{164}$, da mesma forma que antes aprontaram Damanaka e Dimna, ironicamente porque o Mergulhador - tal como os touros de outrora - provocava tamanho deleite no rei que o levou a negligenciar muitos de seus colaboradores e tarefas.

Ao término do fabulário, livre do perigo que o rondara, o chacal percebe que não é possível a manutenção daquela relação, e se afasta, pois, de outra forma, seria inevitável que outros perigos atravessassem seu caminho. No afastamento do poder, o Mergulhador passa a se devotar exclusivamente à religião e à retidão de sua conduta, reafirmando como verdadeiros seus propósitos e procederes ao longo de toda a obra.

Um último comentário acerca desse personagem, antes de encerrarmos sua análise: há, além do saber e da sua relação com o poder, outro ponto de ligação entre ele, Damanaka e Dimna: os três são responsáveis pela morte dos touros e búfalos que servem como motes às fábulas. Damanaka prepara um ardil para que o leão mate Samjĩvaka, da mesma forma que Dimna age contra Xanzaba, provocando, igualmente, sua morte. Guardadas as vicissitudes e acontecimentos que advêm de cada uma dessas ações, nenhuma delas é considerada adequada ou justa; são, pelo contrário, elementos que relativizam a conduta dos chacais mencionados, e trazem tristeza aos leões, chegando até mesmo a ser motivo de punição a Dimna. Ocorre que, neste fabulário, é também o chacal o responsável pela morte do búfalo que tanto atormentara o leão inicialmente, mas, aqui, ao contrário das demais obras, isso não influencia negativamente ou sequer desestabiliza a construção moralmente irrepreensível do Mergulhador; conforme menciona Jarouche a respeito disso, a justeza de ação do chacal jamais é colocada em xeque

${ }^{164}$ ANÔNIMO. O leão e o chacal Mergulhador. Tradução de Mamede Mustafa Jarouche. São Paulo: Editora Globo, 2009, p. 101. 
pelo texto. Para o estudioso, esta seria uma diferença que expõe modelos distintos de sociedade política, pois, se nas primeiras obras os touros eram aceitos no convívio do reino embora fossem radicalmente diferentes dos demais - e sequer partilhassem os mesmos hábitos alimentares -, a sociedade que O leão e o chacal Mergulhador ilustra já não abre espaço ao diferente. Aqui, extrapolamos a ideia para apontar que as sociedades anteriores - caso mantenhamos essa leitura - não apenas aceitavam o diferente como reconheciam nele valor, pois, conforme o trabalho já expôs exaustivamente, os touros Samjĩvaka e Xanzaba eram personagens a quem os reis, ao travar relações, passavam a admirar, respeitar e consultar, mantendo-os próximos em seus círculos de influência, personagens aos quais não é possível negar o reconhecimento de uma parcela considerável de saber. Os touros dos fabulários anteriores são, inclusive, personagens contadores de fábulas, o que nos leva a defender a hipótese de que eles são, também, detentores do saber.

No caso do búfalo, que não chega sequer a ser nomeado, é interessante relembrar que o rei sabe de que animal se trata, mas teme não conseguir fazer frente a ele, num posicionamento já de saída destoante dos demais leões frente às diferenças, e, ao provocar a morte daquele que passara então a ser tomado como inimigo, o Mergulhador é tido como triunfante e chega a ter sua artimanha laureada pelo leão, que, em resposta a ela, insiste na aproximação com o chacal. Assim sendo, a artimanha do chacal, além de não ser questionada, passa a ser elogiada. O leitor não chega a ter contato com o búfalo e, por conseguinte, fica incapacitado de dizer qualquer coisa - positiva ou negativa - a respeito dele, sobrando apenas as ausências, que, na comparação entre obras, apontam para possíveis significados.

Antes de encerrarmos este capítulo, consideramos interessante apontar uma outra repetição, que figura nos quatro fabulários estudados: o papel do amigo. Aqui, neste fabulário em específico, observamos que o amigo do Mergulhador não é identificado como nenhum animal. A julgar pelas obras anteriores, o amigo do personagem-tipo associado ao saber, aquele que lhe dá conselhos - sendo ou não ouvido - é sempre outro da mesma espécie, seja o chacal Karațaka no Pañcatantra, o chacal Kalīla no livro de Kalīla e Dimna ou o raposo Tariq no Livro do tigre e do raposo, o que nos leva a supor que, neste livro, trata-se também de um chacal. Defendemos ainda o fato de ser um animal da mesma espécie, pois, além dos motivos alegados, constituiriam os amigos outra face do saber, mais associada à precaução e ao comedimento que à sagacidade e astúcia. Aparentemente, faz parte da estrutura desses fabulários a existência de um personagem que aconselha o personagem-tipo que metaforiza o saber e, também ao que 
parece, esse personagem, embora se comprove depois, tenha sempre conselhos bastante acertados, é pouco ouvido ou considerado. De modo geral é possível reconhecer em todos os seus discursos o aviso "afaste-se do perigo", sempre num prelúdio que se confirma. Ironicamente, os personagens que representam o saber são alertados do risco que suas ações podem lhes trazer, mas, mesmo assim, dão continuidade a elas. 


\section{Capítulo IV}

\section{Discussões}

\section{Contexto histórico em que os fabulários se inserem}

Até o momento o trabalho trouxe breves pinceladas sobre o período histórico, religioso e cultural em que cada um dos fabulários se insere, sem que, com isso, tenha podido se aprofundar nos contextos em que foram produzidas as composições. Tentaremos a partir de agora dar conta dessa necessidade, contemplando, tanto o período que precede o compêndio indiano como aqueles que abarcam a produção de cada um dos fabulários.

Ao fazer isso, não pretendemos criar uma relação direta entre contexto histórico e fábula, nem muito menos dizer que os compêndios estudados são fruto apenas das relações históricas ou que a refletem, inadvertidamente. Trata-se de um recurso que visa apenas oferecer mais ferramentas para análise pois, da mesma forma que seria incoerente relacionar diretamente os dois elementos, ignorar os laços históricos resultaria em um estudo igualmente equivocado.

A respeito disso, Aderson se refere à Chassang para dizer que “é nas tradições populares mais extraordinárias onde há sempre algo de verdadeiro, mesmo que elas relacionem os fatos alterados ou falsos, pois elas são o eco ingênuo e por consequência fiel das crenças, dos sentimentos, das paixões de um povo e de uma época”165.

\section{Pañchatantra - A Índia do século XV a.C. ao I d.C.}

A história da Índia é longa, antiga e diversa, abarcando, em vários momentos, muitas partilhas de poder dentro do extenso subcontinente. É uma das mais antigas civilizações a se estabelecer e uma das principais fontes de inovações tecnológicas e filosóficas do mundo antigo. Uma apresentação do contexto histórico do Pañcatantra já encontra, portanto, uma série de empecilhos inevitáveis, derivados tanto da dificuldade natural em delinear uma história do subcontinente indiano, como pela sua já mencionada amplitude - além das dificuldades resultantes do menor foco que a academia ocidental dá a seu estudo em comparação a estudos das sociedades grega, romana e egípcia. A estes problemas soma-se ainda a escassez de

${ }^{165}$ Chassang, “Histoire du roman et de ses rapports avec l'histoire dans l'antiquité grecque et latine”, p.11 apud ADERSON, 1990, p. 13. 
registros históricos indianos prévios ao século II a.C., que leva historiadores a se apoiarem em trabalhos de outras naturezas e fontes, como a literatura indiana e a historiografia grega ${ }^{166}$.

Temos como indícios acerca do contexto do Pañcatantra apenas seu período de elaboração (século I d.C.) ${ }^{167}$, a forte presença de características precedentes do hinduísmo e suas particularidades socioculturais, que nos permitem afirmar com alguma segurança que o livro foi produzido por uma sociedade que tinha forte contato com a religião dos brâmanes. ${ }^{168}$. Amparados por esses vagos direcionamentos ao estudo e enfrentando a grande dificuldade inerente a qualquer levantamento historiográfico da Índia pré-islâmica, tentaremos expor o contexto histórico do livro da melhor maneira possível.

Marcada por uma série de migrações, invasões, conquistas e mudanças climáticas que se deram no subcontinente e seus arredores, a Índia tem uma história de grande complexidade. Sua composição étnica, linguística e cultural é extremamente variada, abarcando elementos de diversos povos. Devido às características peculiares do subcontinente indiano, a Índia tendeu a ser conquistada, invadida e receber ondas imigratórias, e raramente o contrário - segundo Rapson (1922), um dos motivos que propiciaram esse contexto é sua característica peninsular, e, além disso, a barreira geográfica natural dos Himalaias. De qualquer forma, ocorre que a Índia, salvo períodos de maior influxo externo, em geral manteve-se politicamente isolada, formando impérios não expansivos e chegando, em certos períodos, a afastar-se do restante do mundo ou, ao menos, do mundo ocidental. O Pañcatantra é elaborado justamente no período de transição entre uma dessas eras de grande influxo, que seguiu a investida alexandrina sobre o território indiano, e um período no qual o comércio com o ocidente foi reduzido, fato que corrobora nossa sugestão de influências mútuas entre as fábulas gregas e indianas do período. 169

Dentre as migrações, uma das primeiras e mais importantes - representando a primeira entrada no território indiano de uma civilização já organizada - é a chegada (por volta do século XV a.C.) de povos que falavam uma língua hoje reconhecida como indo-européia ou protoindo-européia ao subcontinente indiano. Esses povos formaram a base da sociedade brâmane,

\footnotetext{
166 RAPSON, E. J. (ED.). The Cambridge History of India: Volume 1, Ancient India. . London: Cambridge University Press, 1922. v. 1. pp. 56-62.

${ }^{167}$ FLEMMING, M. E.; VARGAS, M. V. A. DE M.; TESHEIMER, M. DA G. (TRADS.). Pañcatantra: Fábulas Indianas - Livro I. . 2. Ed. São Paulo: Humanitas, 2004. v. 1

168 VARGAS, M. V. A. DE M. Do Pañcatantra a La Fontaine: tradição e permanencia da fábula. . São Paulo: Universidade de São Paulo, 1990. Pp. 49-50.

169 RAPSON, E. J. (ED.). The Cambridge History of India: Volume 1, Ancient India. . London: Cambridge University Press, 1922. v. 1. pp. 37-40.
} 
na qual o Pañcatantra se insere. Convencionados historicamente sob a égide de "arianos", e provavelmente provenientes da planície mesopotâmica, não representavam a primeira civilização desenvolvida presente em território indiano, mas, por serem precedidos por uma civilização que estava já em processo de ruína - anterior à chegada desse povo -, são o ponto de partida e principal foco deste estudo historiográfico. ${ }^{170}$

Dos arianos deste período inicial não se sabe, porém, muito além de suas práticas econômicas: eram pecuaristas seminômades, mas, após certo tempo no subcontinente, passaram a habitar cidades e trabalhar com a agricultura, possivelmente influenciados pela civilização que substituíram. Um conflito de certa importância para a região ocorreu entre os séculos X e VII a.C., formando a base do que viria a ser o Mahãbhãrata ${ }^{171}$. Em geral, esse período inicial da civilização é a fonte de uma grande quantidade de lendas que povoarão os períodos posteriores, formando a base da mitologia desse povo. ${ }^{172}$

Esse período semi-mitológico da civilização ariana trouxe consigo a instituição do posto de rei e o crescimento do poder da classe sacerdotal, os brâmanes, que tomaram para si a função de revestir o posto e a pessoa do rei com símbolos do divino. O povo dâsa ${ }^{173}$ é também assimilado pela sociedade ariana, mas, devido a preconceitos baseados em características fenotípicas e culturais diferenciadas, os dâsa foram sistematicamente excluídos da sociedade ariana, levando à instituição do que um dia vem a ser o sistema de castas indiano ${ }^{174} \cdot{ }^{175}$

Cabe aqui elaborar um pouco mais as divisões existentes entre as castas: neste período, elas seriam divididas entre os brâmanes (que tinham funções religiosas e de produção intelectual), os xátrias (aos quais cabiam as funções da guerra e administração civil), os vaixás (inicialmente agricultores, eventualmente mercadores) e os sudras (servos e escravos dâsa, que eventualmente tomaram a posição de artesãos e camponeses livres dentro da sociedade); as castas tinham características religiosas, dividindo inclusive a população entre dois sistemas religiosos, um dos quais era reservado aos brâmanes, xátrias e vaixás, ou seja, às castas arianas, e outro, seguido pelos sudras ou dâsa, que não podiam participar dos cultos e cerimônias

\footnotetext{
170 THAPAR, R. A History of India: volume 1. New York: Penguin Books, 1990. pp. 9-10.

171 Ibid.

172 Ibid., pp. 10-12.

${ }^{173}$ Palavra que toma eventualmente o significado de escravo na língua sânscrita, como dito em THAPAR, R. $A$ History of India: volume 1. New York: Penguin Books, 1990. p. 13.

${ }^{174} \mathrm{O}$ embasamento, ao menos parcial, do sistema de castas nas diferenças étnicas do povo fica claro quando se considera o significado da palavra sânscrita para casta, varna, que significa originalmente cor. THAPAR, R. $A$ History of India: volume 1. New York: Penguin Books, 1990. p. 15

${ }^{175}$ Ibid., pp. 12-14
} 
reservados às castas superiores. A divisão da sociedade, portanto, era parcialmente fundamentada em preceitos religiosos, e, assim, submetida ao poder sacerdotal dos brâmanes. ${ }^{176}$

Do século VII ao III a.C., a sociedade do norte da Índia desenvolveu diversos reinos e repúblicas, que, ocasionalmente, disputaram o poder regional. Os reinos, por manterem as estruturas religiosas que davam sentido ao posto do monarca, tiveram de manter os brâmanes em sua posição de privilégio e poder, e, consequentemente, o sistema de castas, no qual a teoria social brâmane se baseia, chegou a tal ponto de influência que as relações de casta substituíram as antigas alianças tribais. No espaço econômico, por outro lado, a troca de mercadoria, mesmo que ainda limitada ao subcontinente, começa a tomar uma maior importância econômica, levando ao crescimento das cidades, que passaram a ser centros de troca e de produção artesanal. $^{177}$

Dentre os vários reinos do período, um prevaleceu no conflito contra os demais, e estabeleceu um protótipo do que vieram a ser os impérios indianos dos séculos III a I a.C. O estabelecimento de um império propriamente dito, porém, é interrompido pela rápida e conturbada sucessão de dinastias no período. ${ }^{178}$

Concomitante a esse panorama, que se desenvolvia no norte da Índia, o nordeste da região tornou-se um domínio persa, acarretando um momento de troca cultural entre os povos persas e indianos ${ }^{179}$. O domínio persa no nordeste da Índia não sobreviveu, porém, às invasões de Alexandre, que tomou a região no início de sua curta campanha indiana e estabeleceu governadores gregos como seus representantes na região. Estes vassalos helênicos não foram, porém, capazes de resistir aos poderosos reinos do norte da Índia, que os depuseram. O final dos reinos indo-gregos alexandrinos não significou, porém, o fim da troca cultural entre a Índia e o Ocidente, mas, pelo contrário, em sua intensificação - a investida de Alexandre no nordeste indiano e a população de gregos que permanecem na região abriram a Índia ao mundo helênico e, com isso, trouxeram à região a expansão do comércio e o contato com as produções filosóficas e literárias da Grécia, Pérsia e Egito. ${ }^{180}$

\footnotetext{
${ }^{176}$ Ibid., pp. 13-17

177 THAPAR, R. A History of India: volume 1. New York: Penguin Books, 1990. pp. 13-28

${ }^{178}$ Ibid., pp. 26-27

${ }^{179}$ Como exemplo dos desdobramentos desse encontro entre culturas, pode-se mencionar a semelhança existente entre a escrita do nordeste da Índia e a escrita persa, como visto em THAPAR, R. A History of India: volume 1. New York: Penguin Books, 1990. p. 41

${ }^{180}$ Ibid., pp. 30-33; p. 41; pp. 56-57.
} 
A intensificação do comércio e o contato com outras culturas trouxe rápidas mudanças culturais e econômicas para a sociedade indiana, e, junto com o surgimento de religiões não hinduístas na Índia (o budismo e o jainismo), levou a um desenvolvimento da doutrina religiosa - tanto heterodoxa quanto brâmane, que se viram obrigadas a se adaptar aos novos contextos. Podemos destacar, entre esses contextos, o crescimento das cidades, locais cuja importância econômica crescente e grande proporção de budistas e jainistas na população representava uma ameaça e desafio ao poder brâmane. ${ }^{181}$

O período que seguiu a invasão alexandrina foi marcado também pela constituição de grandes impérios indianos, que mantiveram contato mercantil e diplomático com a Grécia. Esses impérios conseguiram realizar uma certa quebra com a ortodoxia brâmane, dando espaço a outras formas de culto. Foi durante esse período que se deu o início do registro historiográfico indiano - até esse momento o estudo da história da Índia tinha de se valer de fontes míticas ou historiografia grega. ${ }^{182}$

Com a queda de impérios os reinos indo-gregos puderam se estabelecer; esses reinos permaneceram no nordeste indiano por um período considerável de tempo, e deixaram suas marcas. Inevitavelmente, porém, também entraram em um período de decadência, que coincidiu com a invasão simultânea da Báctria ${ }^{183}$ e do nordeste indiano pelos citas, um povo centroasiático que também estabeleceu seus reinados locais, e permaneceu no poder até o século I a.C. ${ }^{184}$, o período que corresponde à compilação do Pañcatantra. ${ }^{185}$

Importante ressaltar que a queda dos reinos indo-gregos e da Báctria, porém, não deve ser vista como uma perda total da comunicação com o ocidente - há até mesmo registros da manutenção dessas relações.

Por fim, vale apontar que a introdução na sociedade dos conquistadores estrangeiros, grupos de indivíduos poderosos que estavam fora do sistema de castas - causou certas dificuldades para os brâmanes da Índia, que tiveram de cuidadosamente adequar os novos integrantes ao seu sistema social vigente - mas nunca em uma posição que correspondia àquela que um nativo indiano ocuparia. Por este motivo, muitos dos conquistadores gregos e citas bem

\footnotetext{
${ }^{181}$ Ibid., p. 34.

182 THAPAR, R. A History of India: volume 1. New York: Penguin Books, 1990. pp. 64-65

183 Terra natal dos povos indo-gregos. Ibid., p. 56.

184 Ibid., pp. 57-58

185 VARGAS, M. V. A. DE M. Do Pañcatantra a La Fontaine: tradição e permanencia da fábula. . São Paulo: Universidade de São Paulo, 1990. Pp. 49-50.
} 
integrados à sociedade indiana não se convertiam ao bramanismo, mas ao jainismo ou budismo. ${ }^{186}$

\section{Kalila e Dimna - O Irã do século VI d.C. ao VIII d.C.}

A conquista da Pérsia sassânida por parte do nascente império árabe foi precipitada pela queda da dinastia árabe pré-muçulmana de Mundhir, líderes/administradores da região de Hira, submissa ao império sassânida. Na virada do século VI d.C. ao VII d.C., os sassânidas depuseram essa família, que tinha certa influência sobre a população árabe local e lá instauram um administrador persa, que não tinha, por sua vez, grande popularidade com a população. ${ }^{187}$ Este ato, aparentemente inócuo e que poderia, de fato, passar despercebido na história do grande império sassânida acabou por precipitar sua ruína, visto que no mesmo período em que alienavam a população de um de seus domínios árabes, o povo árabe começava a se unificar sob a bandeira de Muhammad - o que seria apenas uma população revoltosa em um território de baixa importância tornou-se, por meio da aliança com o nascente império árabe, o evento que precipitou a queda do império persa. Abu Bakr, primeiro dos califas árabes, não demorou muito após sua ascensão para aliar-se às tribos da região e, juntos, os árabes tomaram o território da Hira em um espaço muito curto de tempo ${ }^{188}$.

A investida árabe em território persa foi, porém, interrompida por questões internas, e retomada apenas no período de 'Umar, segundo dos califas. A capital do império persa não tarda, após a retomada do conflito, a ser conquistada ${ }^{189}$, não representando, porém, a queda do império sassânida em si, que perdurou em suas províncias orientais ainda por um tempo. Qualquer possibilidade de retomada do poder por parte dos sassânidas foi, porém, arrasada em uma única grande batalha, por volta da metade do século VII d.C. ${ }^{190}$, firmando, portanto, a supremacia do império islâmico sobre a região - em menos de um século de existência, as crenças de Muhammad levam um povo fragmentado e nômade ao que, neste ponto da história, já era inegavelmente um império em ascendência. Apesar da visível potência da organização política, social e espiritual da nova sociedade árabe, a queda repentina de um império de tão

\footnotetext{
186 THAPAR, R. A History of India: volume 1. New York: Penguin Books, 1990. Ibid., pp. 77-78

187 FRYE, R. N. The Cambridge History of Iran: Volume 4: The Period from the Arab Invasion to the Saljuqs. London: Cambridge University Press, 1975. pp. 2-3.

188 Ibid., pp. 3-8.

${ }^{189}$ Ibid., pp. 9-13

190 Ibid., pp 13-17
} 
longínqua história e renomado nome como o império sassânida ainda causa espanto, induzindonos a perguntar: O que poderia ter levado este grande império à ruína em menos de meio século?

A desigualdade entre as classes no Irã, a falta de cooperação entre elas, as grandes diferenças religiosas dentro do império, uma crença geral no fatalismo e no poder do destino, o grande número de heterodoxias e grupos cristãos, que em geral alinharam-se com os árabes no conflito e a decadência do poder sassânida, que havia exaurido totalmente o tesouro nacional, gastando o pouco que restava em cerimonialismo vazio; a bancarrota espiritual e material da classe dominante sassânida - todas estas foram citadas como possíveis fatores centrais na queda do império frente à invasão árabe ${ }^{191}$. De fato, todas devem ter tido sua influência sobre a ruína do poder sassânida, e, quando considerados à luz da maior tolerância religiosa da sociedade árabe, os motivos por trás da queda do império tornam-se ainda mais aparentes.

Vale ressaltar, porém, que, mesmo após a queda irreversível do poder sassânida, partes do território persa ainda não estavam sob domínio califal - a consolidação final do território do antigo império persa só é efetuada no período omíada - e mesmo essa consolidação territorial não trouxe a estabilidade política dentro da região. Muitos levantes populares e tentativas de firmar reinos independentes ocorreram durante o período omíada, e a região só viu maior estabilidade sob o governo dos abássidas. ${ }^{192}$

Nesse momento já houve a introdução em grande escala do pagamento da jizya, imposto sobre práticas religiosas que não o islã proposto por Muhammad ${ }^{193}$, que se aplicaria, teoricamente, apenas a seguidores de religiões abraâmicas e, que, de fato (tanto por questões ideológicas quanto, possivelmente, políticas), durante o período dos primeiros califados excluía os praticantes do zoroastrismo, uma antiga religião persa, que, portanto, não gozava da mesma liberdade religiosa e privilégios que tinham os cristãos e judeus. Antes, porém, do final do primeiro período da história califal, eles foram incluídos nesse sistema. Outro fato interessante é que, enquanto durante os califados Rashidun havia muita quebra de tratados entre os árabes e não-islâmicos ${ }^{194}$, no período omíada, o uso da estrutura de arrecadação sassânida, muitas vezes remetida a lideranças locais zoroastras levava a situações nas quais indivíduos de religiões que não o islã pagavam menos imposto que muçulmanos não árabes recém convertidos - muitas

\footnotetext{
${ }^{191}$ FRYE, R. N. The Cambridge History of Iran: Volume 4: The Period from the Arab Invasion to the Saljuqs. London: Cambridge University Press, 1975. p. 17.

${ }^{192}$ Ibid., pp. 18-19

${ }^{193}$ Ibid., p. 20. Aqui se apresenta o exemplo de uma cidade inteira se entregando aos árabes mediante pagamento deste impo.

${ }^{194}$ Ibid., p. 26
} 
vezes em ato de punição pelo seu abandono da fé antiga ${ }^{195}$. Essa última situação é emblemática do tratamento dado aos muçulmanos não árabes durante o período omíada. Além de não terem garantidos os poucos direitos que possuíam, não gozavam do mesmo status social nem possuíam os mesmos direitos dos árabes, situação que, como veremos adiante, é inseparável da construção de estado omíada e que, com o crescimento da conversão dos povos não árabes, leva à queda dos omíadas e a instituição da dinastia dos abássidas. ${ }^{196}$

O califado omíada, entendendo que a mera identidade religiosa não seria capaz de manter coesa a sociedade árabe, tentou constituir o que poderia ser considerado um estado árabe, baseado em uma ideologia de governo árabe e voltado à defesa dos direitos do povo árabe (mesmo que às custas dos demais). Para garantir ainda mais sua legitimidade, a dinastia revestiu-se de símbolos de opulência e poder, formando uma simbologia do poder própria que, ao separá-los de seus súditos, garantiriam a validade de sua posição de poder ${ }^{197}$. Como já foi dito, os omíadas reinstituíram os sistemas de arrecadação de imposto sassânida, que alienaram seus súditos muçulmanos não árabes ${ }^{198}$. Este sistema funcionou suficientemente bem, porém, por um grande período de tempo, e os omíadas permaneceram no poder da segunda metade do século VII d.C. ao final da primeira metade do século VIII d.C., mas as circunstâncias tanto dos territórios conquistados como da própria corte omíada alteraram-se com o passar do tempo, com os califas tornando-se cada vez mais corruptos e a população dos territórios conquistados passando a tomar a forma de seguidores não árabes de Muhammad ${ }^{199}$. Isso era algo para o qual o modelo omíada de governo não estava preparado, já que prezava pela tolerância religiosa e a manutenção de sistemas burocráticos persas como forma de manter a paz, por um lado, e pela valorização do árabe e sua cultura guerreira como forma de legitimar seu poder, por outro - não havia espaço nessa estrutura para os islâmicos não árabes e, de fato, eles tomaram a frente de grande parte dos movimentos rebeldes do final do califado ${ }^{200}$.

Nesse contexto, com o crescimento do poder xiita e de outras heterodoxias, e especialmente na sua influência sobre os muçulmanos não árabes ${ }^{201}$, o cenário estava formado para a tomada de poder pelos abássidas na metade do século VIII d.C. Após uma longa

\footnotetext{
${ }^{195}$ FRYE, R. N. The Cambridge History of Iran: Volume 4: The Period from the Arab Invasion to the Saljuqs. London: Cambridge University Press, 1975, pp. 47-48.

196 Ibid., pp. 38-43.

197 Ibid., p. 39.

198 Ibid., p. 48.

199 Ibid., pp. 27-29.

${ }^{200}$ Ibid., p. 38.

${ }^{201}$ Ibid., pp. 35-38.
} 
campanha de propaganda religiosa secreta ${ }^{202}$, culminando em um levante repentino (que partiu de território iraniano) ${ }^{203}$, os abássidas conseguiram tomar o poder do califado. A base de poder dos abássidas - um grupo militar da região de Curasão formado tanto por árabes quanto não árabes, em uma igualdade de direitos que não era vista nem possível no tempo dos omíadas teve efeitos perceptíveis na organização de seu poder $^{204}$. Ao invés de se estabelecerem em Damasco, a capital do império omíada, os abássidas instituíram seu poder primeiro em Kufa última capital dos califas Rashidun e localizada em território iraquiano, mais próximo do Irã e, portanto, Curasão - e, depois, em Baghdad, próxima a Kufa. Algo de importância ao mestrado deve ser aqui marcado: além de basearem muito mais de sua ideologia de estado na defesa do Islã do que os omíadas, os abássidas, por terem estabelecido aliança com os zoroastras - além de buscarem legitimidade no Islã, os abássidas também se valeram da simbologia imperial persa - eram também menos tolerantes às religiões heterodoxas da antiga Pérsia, em especial o maniqueísmo, a antiga religião de Ibn Al-Muqaffa ${ }^{\mathrm{c}}$ antes de sua conversão ao Islã ${ }^{205}$.

É este, em suma, o contexto histórico no qual se insere o Kalila e Dimna: a queda da corte omíada e a ascensão dos abássidas e da população do antigo Irã.

\section{Livro do tigre e do raposo - O Irã do século VIII d.C. ao IX d.C.}

Este livro foi escrito por Sahl Bin Harun, um escriba de importância, durante o califado de al-Ma’mun ${ }^{206}$ - sétimo dos califas abássidas - em uma época de turbulência nesta sociedade. O período dos primeiros califas abássidas trouxe grandes mudanças na sociedade islâmica, e eventos que ocorreram durante os califados que antecederam o de al-Mamum deixaram suas marcas na sociedade. Assim sendo, e levando em conta os levantamentos já apresentados anteriormente - que nos trouxeram até o período do segundo califa abássida - nos deteremos, nesse momento de nosso estudo, às circunstâncias da sociedade califal a partir de al-Mahdi, o terceiro dos abássidas, dando, porém, pouca atenção ao curto governo de al-Hadi, e procurando

\footnotetext{
${ }^{202}$ FRYE, R. N. The Cambridge History of Iran: Volume 4: The Period from the Arab Invasion to the Saljuqs. London: Cambridge University Press, 1975, pp. 48-52.

${ }^{203}$ Ibid., pp. 52-54.

204 Ibid., pp. 54-58.

205 Ibid., p. 33.

206 HĀRŪN, S. BIN. Livro do Tigre e do Raposo. Tradução de Mamede Mustafa Jarouche. São Paulo: Amaral Gurgel Editorial, 2010, p. 10.
} 
desenvolver mais detalhadamente os governos de al-Rashid e al-Ma'mum, mais longos e importantes para compreender o contexto da produção da obra.

Comecemos então por al-Mahdi: seu califado foi marcado pela continuação das reformas abássidas, a criação de novos ministérios e grandes e importantes inovações administrativas no que concernia a supervisão dos ministérios ${ }^{207}$. Durante este período a família dos barmecidas ${ }^{208}$ - que tiveram grande importância como conselheiros, ministros e governadores durante o início do período abássida - começou a estabelecer sua importância e tomar sua posição como representantes do saber ao lado dos governantes.

Após o reino de al-Mahdi e o curto governo de seu filho, seguiu o califado al-Rashid, cujo reinado, longo e frutífero, trouxe uma série de inovações à sociedade abássida - ele reverteu a tendência centralizadora do califado ${ }^{209}$, permitindo um grau elevado de autonomia aos governadores das províncias. De grande importância para o contexto de um fabulário que entabula as relações entre poder e saber, al-Rashid também instituiu o aconselhamento religioso como mais uma das práticas dos vizires ${ }^{210}$, além das funções de administração e aconselhamento que eles já exerciam. Isso resultou em uma valorização ainda maior do cargo de vizir, que se viu então como detentor tanto do posto de saber político quanto do saber religioso - sendo este último altamente valorizado na sociedade islâmica califal.

Ocorreu que, apesar de ter revestido o cargo de vizir de ainda maior valor e novamente tê-lo entregado à (agora já estabelecida como uma quase dinastia de conselheiros, servidores públicos, e governadores de província) família dos barmecidas - ou, quem sabe, justamente por arrepender-se - al-Rashid se voltou contra a família de sábios, matando o ex-governador barmecida de Curasão - particularmente bem quisto pela população local - e aprisionando todos os outros membros ${ }^{211}$. Não há muito mais do que especulações acerca dos motivos por trás do ato de al-Rashid. Os ataques de al-Rashid aos barmecidas, porém, não passaram incólumes: o povo de Curasão, que formava um importante centro do poder abássida e que nutria bons sentimentos em relação ao seu antigo governador barmecida, eventualmente se levantou contra

\footnotetext{
${ }^{207}$ FRYE, R. N. The Cambridge History of Iran: Volume 4: The Period from the Arab Invasion to the Saljuqs. London: Cambridge University Press, 1975, pp. 66-69.

${ }^{208}$ Ibid., p. 68. Os barmecidas foram especificamente citados neste momento tanto por sua importância para a história árabe quanto por ocuparem a posição do saber em relação direta com o poder - mas, além destes fatores, nos interessa também o desfecho de sua história, que será apresentado nos parágrafos seguintes.

${ }^{209}$ Ibid., p. 69.

${ }^{210}$ FRYE, R. N. The Cambridge History of Iran: Volume 4: The Period from the Arab Invasion to the Saljuqs. London: Cambridge University Press, 1975, p. 70.

${ }^{211}$ Ibid., pp. 70-71
} 
o novo governador nomeado pelo califa, marcando uma cisão da população de Curasão com os abássidas $^{212}$.

Al-Rashid passou então seus últimos anos viajando por seu domínio, tentando apaziguar os ânimos de seus súditos e efetuando reformas administrativas por onde passava. Quando morreu, dividiu seu domínio entre três filhos, sendo que al-Amin herdou o título califal e todos os territórios ao oeste de Hamad-na e al-Ma’mun herdou os territórios ao oeste - dentre os quais, Curasão ${ }^{213}$.

Como costuma ocorrer na ocasião da divisão de um domínio entre vários pretendentes, o período que seguiu a morte de al-Rashid foi marcado por grandes conflitos dentro da sociedade abássida - al-Ma’mun, filho de uma mulher iraniana, encontrou grande apoio da população de Curasão, que formava parte importante do poder de seu território e que, devido aos atos impensados de al-Rashid, era avessa ao domínio de Bagdá ${ }^{214}$. Enquanto al-Ma’mun era glorificado pelo povo de suas províncias, al-Amin manobrava na tentativa de centralizar o poder na figura do califa e tornar-se incontestado em seu domínio do califado - seu primeiro passo foi a remoção do terceiro filho de al-Rashid do governo de suas províncias fronteiriças. Em seguida, exigiu de al-Ma'mun o controle de suas terras, e naturalmente, recebeu uma recusa, que levou à declaração de guerra entre os dois. A tentativa de tomada de poder de al-Amin falha, porém, e, após uma guerra curta, al-Ma’mun toma o controle de Bagdá ${ }^{215}$ e declara-se o sétimo califa abássida. Curiosamente, sua campanha repete mesmo processo de conquista de leste a oeste do califado com o auxílio de um exército de Curasão que coloca os primeiros abássidas no poder. Devido a essa tomada da capital iraquiana por um exército iraniano e a permanência de al-Ma'mun nos territórios orientais do império, a população do Iraque, após sua tomada de poder, o vê como um invasor em seu território ${ }^{216}$.

Apesar dos ressentimentos causados pelo conflito de sucessão, o período de Al-Ma’mun foi marcado por grande produção cultural, intelectual e teológica - é neste período que a Bayt al-Hikma deixa sua marca no mundo islâmico ${ }^{217}$ - bem como por reformas religiosas instituídas

\footnotetext{
${ }^{212}$ FRYE, R. N. The Cambridge History of Iran: Volume 4: The Period from the Arab Invasion to the Saljuqs. London: Cambridge University Press, 1975, pp. 71-72

${ }^{213}$ Ibid., p. 72.

214 Ibid., p. 71.

215 Ibid., pp. $72-73$

216 Ibid., p. 73.

${ }^{217}$ HĀRŪN, S. BIN. Livro do Tigre e do Raposo. Tradução de Mamede Mustafa Jarouche. São Paulo: Amaral Gurgel Editorial, 2010, p. 10.
} 
pelo califa na tentativa de recuperar a lealdade das províncias centrais de seu império ${ }^{218}$. O domínio deste grande governador acaba, porém, com sua morte na última grande empreitada que os abássidas levantaram contra o império bizantino, e seu término marca também o final da era do poder de Curasão sobre a política abássida ${ }^{219}$. O próximo califa, Al-Mu’tasim - irmão de al-Ma'mun de ascendência turca - refaz a base de seu poder militar a partir do uso de escravos turcos, e assim quebra a dependência abássida a Curasão ${ }^{220}$.

\section{O leão e o chacal Mergulhador - O Irã do século IX d.C ao XI d.C.}

Retomamos nossa contextualização histórica das obras da tradição árabe após um hiato de quase trezentos anos, no qual, de fato, muito ocorreu - entendemos, porém, que, devido à grande extensão de tempo entre a era de al-Ma’mun e a época na qual se situa aproximadamente - a obra de autoria desconhecida, não é interessante fazermos um percurso muito detalhado da totalidade do período, bastando a nós dizer que, durante este período, o exército turco criado por al-Mu’tasim cresceu continuamente em influência, tornando-se, durante parte dele, a maior força política do império ${ }^{221}$; que um enfraquecimento do poder califal levou ao estabelecimento de dinastias independentes ${ }^{222}$; que o império reduziu seu escopo, chegando a perder Curasão, outrora uma parte essencial do califado ${ }^{223}$; e que, ao longo de dois califados, tentou-se retirar o poder político das mãos do exército por meio do fortalecimento da burocracia califal ${ }^{224}$. É a partir deste ponto da tentativa de retomada do poder, escolhido arbitrariamente, que iremos abordar a queda de poder dos abássidas.

Após longo período de domínio militar, dois califas abássidas, al-Mu’tadid e al-Muktafi - deparando-se com um exército que não mais respeita e obedece aos abássidas - fortalecem a burocracia do estado, tentando criar novas figuras de poder às quais o exército teria de obedecer. Durante certo tempo, a artimanha teve seu sucesso: os militares passaram a considerar, após certo tempo, os burocratas como seus superiores, e a lhes obedecerem. O sucesso dos califas foi, porém, apenas temporário, pois o poder entregue aos burocratas resultou em seu mau uso e

\footnotetext{
${ }^{218}$ FRYE, R. N. The Cambridge History of Iran: Volume 4: The Period from the Arab Invasion to the Saljuqs. London: Cambridge University Press, 1975, p. 74

${ }^{219}$ Ibid., p. 74.

${ }^{220}$ Ibid., pp. 74-75.

${ }^{221}$ Ibid., pp. 76-78.

${ }^{222}$ Ibid., p. 78.

${ }^{223}$ Ibid., p. 79-80.

${ }^{224}$ Ibid., p. 79.
} 
apropriação $^{225}$, e, por este motivo, associado à ascensão de um general de nome Mu'nis, que comandava o respeito e a lealdade dos soldados, o poder novamente retornou às mãos do exército $^{226}$. Notando a ameaça que este comandante representava ao seu poder, o califa alMuqtadir, após tentar assassiná-lo sem hêsito ${ }^{227}$, se revestiu com uma série de símbolos (literais) do poder dos abássidas e entrou em confronto direto com seu general - o que resultou em sua morte ${ }^{228}$.

Segui então um período de caos, no qual o poder abássida esfacelou-se ainda mais, culminando na entrega, pelo califa al-Radi, da corte e do comando do exército a um líder militar semi-independente, Ibn Ra’iq, que se tornou efetivamente o administrador de facto do império, iniciando um período no qual a administração do império, à exceção de dois civis, estava na mão de soldados profissionais ${ }^{229}$. Nesta primeira porção do chamado período dos comandantes supremos, porém, os líderes militares que alcançavam o poder não possuíam poder militar suficiente para estabelecer uma real dinastia de poder ao redor dos califas ${ }^{230}$ - o momento das dinastias de comandantes supremos só chega com os Buídas, uma família de dailamitas ${ }^{231}$ (povo que compunha nessa época uma grande parcela do exército iraquiano, ocupando a posição da infantaria), que detinham uma forte base militar no platô iraniano. A chegada dos Buídas foi vista como um grande marco na história califal ${ }^{232}$ - os Buídas detinham poder militar numa escala muito superior dos comandantes anteriores e, por esta razão, foram capazes, ao contrário dos comandantes supremos anteriores, de estabelecer um poder dinástico ${ }^{233}$. Vale apontar que, com a tomada de poder pelos Buídas, se reestabeleceram as ligações entre Iraque e Irã, visto que a família dos Buídas também detinha controle de parte do Irã ${ }^{234}$.

Há então um período relativamente longo de controle do Iraque pela dinastia dos Buídas. Para manterem seus poderes, eles valeram-se tanto do nome e da figura do califa ${ }^{235}$ como do estabelecimento de um sistema que, segundo Frye (1975), assemelhou-se ao de uma ditadura

\footnotetext{
${ }^{225}$ Ibid., pp. 79-80.

${ }^{226}$ FRYE, R. N. The Cambridge History of Iran: Volume 4: The Period from the Arab Invasion to the Saljuqs. London: Cambridge University Press, 1975, pp. 71

${ }^{227}$ Ibid., p. 82.

${ }^{228}$ Ibid., p. 82.

${ }^{229}$ Ibid., p. 83-84.

${ }^{230}$ Ibid., p. 84.

${ }^{231}$ Povo que compunha nessa época uma grande parcela do exército iraquiano, ocupando em geral a posição da infantaria.

232 Ibid., p. 85.

233 Ibid., p. 85.

${ }^{234}$ Ibid., p. 85.

235 Ibid., pp. 250-251
} 
militar ${ }^{236}$, construído de forma a manter a estabilidade dentro de uma sociedade pautada no poder bélico. Seguiu-se uma série de conflitos ao longo dos quais os buídas primeiro consolidaram, depois começaram a perder seu poder e influência, e então se iniciou o período estimado da feitura do Livro do leão e do chacal Mergulhador - o momento entre a queda final do poder dos buídas e a entrada dos seljúcidas ${ }^{237}$ - o livro se desenvolve, portanto, dentro de um império esfacelado, cercado por fortes inimigos ou, como diz Jarouche (2009): “Contemporâneo das Cruzadas e do processo de esfacelamento do poder califal abássida” 238 .

\section{Literatura e Fábula}

Estabeleceu-se, no início desta dissertação, um corpus de obras que serviram de apoio, em maior ou menor grau, à construção de nossas hipóteses. Tal corpus é composto, conforme dito anteriormente, por Pañcatantra, Kalīla e Dimna, Livro do tigre e do raposo e O leão e o chacal Mergulhador e é, assim como todos os recortes, de natureza subjetiva. Ele poderia ser justificado por uma série de elementos que, elencados, aproximariam as obras umas das outras, da mesma forma que, em contrapartida, também poderiam ser afastadas, por critérios tão justificáveis e cabíveis como os primeiros. Destarte, vale dizer, sobre a escolha e recorte de obras, algumas palavras. No que segue, arrolamos os critérios que nortearam sua escolha.

De início, poderíamos classificar essas obras como pertencentes ao âmbito de uma “Literatura Universal”. À primeira vista bastante geral, tal classificação ora se justifica, porquanto se tratam de registros narrativos que chegaram a nós sob a forma de composições escritas regidas por uma série de princípios e normas estéticas (das quais, trataremos a seu tempo), ora é problemática, já que nem todos os textos referidos foram concebidos e veiculados, originalmente, neste formato nem sequer o vislumbravam, tendo em vista serem fruto dos modos de composição e transmissão peculiares da cultura oral. Contudo, neste trabalho optamos por considerá-las como da tradição escrita, já que nessa forma foram transmitidas à posteridade e se mantiveram, tanto quando possível, fixadas. Na passagem do oral ao escrito, independentemente de sua origem, elas decerto foram adaptadas às regras e formas da narrativa constituída como fazer literário, e a partir destas particularidades serão consideradas.

\footnotetext{
236 Ibid., p. 251.

${ }^{237}$ Ibid., p. 251.

238 ANÔNIMO. O leão e o chacal Mergulhador. Tradução de Mamede Mustafa Jarouche. São Paulo: Globo, 2009. p. 195
} 
Ainda assim, caracterizá-las como obras literárias exige nova série de cuidados e questionamentos, pois, defini-las como tal implica assumir um posicionamento acerca do que se entende por Literatura. O que nos impede, a princípio, de, adotando outros critérios, classificá-las como tratados ou manuais? A obra indiana, em seu contexto nativo, era considerada um nîtisâstra ou "tratado de conduta", e as obras posteriores lidam de tal forma com a política e seus meandros que, se adotados outros parâmetros, poderiam ser consideradas, justificadamente, manuais políticos com certo grau de didatismo. Assim sendo, definir essas obras como literárias significa considerar certas características em detrimento de outras e analisá-las como constituintes de um fazer eminentemente literário.

Caímos, então, em uma segunda questão: qual noção de Literatura é cabível aos textos indianos e árabes? É possível classificá-los de acordo com quais critérios?

De acordo com esses recortes, caberia justificar agora o fato de considerarmos as obras como fábulas, enquadrando-as como um gênero literário.

\section{A fábula - definições e considerações}

Não é fácil traçar uma linha que nos leve às origens da fábula, mas é comum que ela seja associada, por suas raízes orais, aos estágios mais iniciais de diferentes civilizações. Embora seja possível encontrar autores que a atribuam tanto à Grécia como à Índia, preferimos nos ater àqueles que, como Nojgaard ${ }^{239}$, associam-na aos povos sumérios da Mesopotâmia. É possível encontrar, já em registros textuais dessa época - de aproximadamente 4.000 a.C. -, o uso de animais como personagens em situações humanizadas/antropomorfizadas e, além disso, um desenvolvimento narrativo próximo do que podemos reconhecer entre os gregos, principalmente nas fábulas esópicas. Destarte, segundo essa teoria as fábulas teriam partido da Mesopotâmia para, em dois ramos, ter chegado aos seus mencionados "berços”: Grécia pela Ásia Menor e Índia pela Pérsia, tal como observamos em Casildo:

La difusión del género fabulístico en la literatura europea parte de una tradición de raíz doble: de un lado, la tradición clásica (Esopo, Fedro, Romulus, Isengrinus) y del otro, la india (Panchatantra, sus versiones árabes, etc.). Y a su vez la colección griega y la india parecen remontar a las fábulas mesopotamias, que, a partir de Babilonia, habrían llegado a Grecia a través de Asia Menor, y por otra parte, a través de Persia, posteriormente, llegarían a la India. Los orígenes mesopotamios del género han sido detectados y estudiados — por Ebeling, Gordon,

${ }^{239}$ NØJGAARD, M., La Fable Antique I, Copenhague, 1964. 
Lambert, Perry, etc.-, aunque es muy difícil precisar lo que luego los griegos añadieron en la formación de este género popular. ${ }^{240}$

Ao se utilizar do termo “fábulas esópicas”, aliás, necessariamente nos remetemos a Esopo (VI a.C.), proeminente nome ao qual muitos conferem a origem das fábulas e de tamanha importância que chega a nomear um estilo de fábula - o esópico -; é inegavelmente um dos principais responsáveis pela disseminação do gênero no Ocidente.

Curiosamente, no entanto, nome tão importante é igualmente discutido: por serem relativamente poucos os registros históricos que dão base à sua existência e produção, é bastante comum que sua autoria seja contestada, e as fábulas “de Esopo” sejam então justificadas como produções populares da época, encaradas como de autoria anônima. Há quem diga que, mesmo tendo existido, Esopo não fizera mais que juntar as narrativas que circulavam popularmente. Apesar da altercação acerca de sua autoria, é possível encontrar tanto em Heródoto (V a.C.) como em Aristóteles (IV a.C.) referências à sua existência ${ }^{241}$, o que nos leva a certa simpatia por essa possibilidade. Apesar disso, há referências em autores que contestam sua primazia no gênero, aludindo-a a autores ainda anteriores, como podemos verificar a seguir:

Pero el género estaba ya atestiguado en Grecia mucho antes, de la existencia, real o literaria, de este curioso personaje, el esclavo frigio que, según los diversos testimonios biográficos, habría vivido en la segunda mitad del siglo VI a. C. Quintiliano designa a Hesíodo como el inventor del género («Nam videtur fabellarum primus auctor Hesiodus», en Inst. V 11, 19). Después de éste, también Arquíloco, Estesícoro y Semónides aluden a algunas fábulas con anterioridad a Esopo. ${ }^{242}$

Seguindo na tentativa de traçado, que almeja situar origens e definições da fábula, nos detemos aos nomes que vão surgindo nessa busca, e aqui damos atenção ao pensador previamente mencionado, Aristóteles. Na investigação das origens históricas do termo, esbarramos no autor e nos remetemos à sua célebre Retórica ${ }^{243}$, que não apenas menciona Esopo como desenvolve definições que conceituam a fábula. Ao que nos chegou de registro, teria sido Aristóteles o primeiro a teorizar sobre a fábula, embora tenha aludido a ela apenas em breves passagens. Considerando-a então como inserida na arte retórica, cabe dizer que ela está, segundo o pensador, entre as técnicas (techné) de argumentação destinadas ao convencimento

\footnotetext{
240 CASILDO, G. L. Introduccion general acerca de las fábulas griegas como género literário. In.: Fábulas de Esopo. Madrid: Alianza Editorial S.A., 1998. p.8.

241 Vale dizer que encontrar referências da existência de um personagem nessas obras não é, necessariamente, atestado de sua existência, justamente porque, naquele momento, em muito se confundia relato historiográfico e ficção: muitos foram os personagens e histórias criados e incorporados a esses registros que, posteriormente, foram comprovados falsos ou inexistentes.

${ }^{242}$ CASILDO, G. L. Introduccion general acerca de las fábulas griegas como género literário. In.: Fábulas de Esopo. Madrid: Alianza Editorial S.A., 1998. p.8.

243 ARISTÓTELES. Retórica. Lisboa: Imprensa Nacional - Casa da Moeda, 1998.
} 
e aos modos de persuasão, como podemos depreender de "a capacidade de descobrir o que é adequado a cada caso com o fim de persuadir" ${ }^{244}$, e, ainda, a "faculdade de descobrir os meios de persuasão sobre qualquer questão dada” ${ }^{245}$.

Contudo, para ele a fábula não seria considerada como um gênero literário ficcional embora fictícia, como trataremos adiante -, mas sim tratada como mais um dos muitos meios aos quais o orador poderia recorrer para atingir a finalidade pretendida - a persuasão. Assim, seria possível definir a fábula, segundo essas características, como uma figura retórica (tal como a parábola), e não como gênero.

Ainda segundo Aristóteles, ela seria uma espécie de exemplo (ou paradigma) constituído por dois aspectos: ficcionalidade e alegoria. Aqui é necessário dizer que, ao teorizar sobre a fábula, ele se refere a ela como logos, enquanto outros escritores gregos se utilizam do termo mythos. Verifica-se o uso indiscriminado de ambos os termos para as mesmas definições, pois, não há, em grego, uma palavra específica para a fábula, mas, ao analisarmos essas aplicações e os significados etimológicos das duas palavras, percebemos que cada uma delas alude a uma característica da fábula em sobreposição às demais: enquanto logos pode remeter à lógica do relato, mythos já traz consigo a ideia de ficção.

Se recorremos a outros manuais de retórica, como as Progymnasmatas de Hermógenes ${ }^{246}$, percebemos que, em concordância com a teorização de Aristóteles, a fábula era definida sobretudo pelo seu emprego retórico e pedagógico. O autor é um dos que se remete às fábulas como mythos, aliás.

De onde viria então a palavra fábula, que foi adotada por nós e pelo Ocidente de modo geral? Reafirmando a sua oralidade original, fábula é uma palavra de origem latina que não apenas se relaciona ao discurso como, em suas raízes etimológicas, trata do fábulare, do falar, ou ainda, da conversação; se refere ao ato de exprimir algo.

Nos dirigindo aos latinos, encontramos um número expressivo de autores que trataram da fábula, sempre em chaves de compreensão próximas às dos gregos, ressaltando seu caráter ficcional e inverossímil. Segundo Quintiliano, em suas Instituições Oratórias, as fábulas estariam associadas ao mesmo nível do conto infantil e seriam bastante adequadas para quando as crianças ainda não fossem capazes de atender às instruções do retor. O autor ainda estabelece

\footnotetext{
244 Ibid., 1998, p. 48.

245 Ibid., 1998, p. 49.

246 As Progymnasmatas são subgêneros dos manuais de retórica, normalmente voltados ao ensino.
} 
diferenças entre as fábulas, definindo-as enquanto elevadas - como a fábula poética, em que se encaixaria a tragédia - e baixas - as fábulas curtas -, e dizendo a respeito das baixas (entre as quais ele acomodava as esópicas) que elas seriam especialmente interessantes àqueles que, ignorantes, ouviam o fingido com mais atenção graças à sua simplicidade, posto que, via de regra, era gente do campo, facilmente enganável pelo aspecto deleitoso das fábulas (ao menos segundo o autor), o público entre o qual ela tinha maior circulação. Essa conceituação poderia ser discutida, pois menospreza a riqueza do conhecimento popular - que, por certo, muito teve a enriquecer pela fábula e para ela -, mas nos manteremos na linha proposta para delinear apenas o que se falou sobre a fábula, tarefa por si só bastante árdua.

Também vale mencionar, na tradição latina, Fedro (I d.C.), escravo liberto de Augusto César e reconhecido como disseminador da fábula na literatura latina, segundo alguns autores, por meio da imitação das composições de Esopo.

Vamos agora, porém, nos encaminhar à Índia, sem que isso represente, necessariamente, um desvio de rota; conforme foi possível observar no levantamento histórico, ela, no período em que foi produzido o Pañcatantra, já tinha contato bastante amplo com a tradição literária e a cultura helênica e latina. Ao buscarmos no sânscrito quais são os termos que se referem ao que chamamos de fábulas, encontramos o uso comum de termos como katha (conversação, história inventada) ou akyhayika (narrativa curta) e podemos perceber que eles não apenas atualizam a noção de oralidade tão mencionada até então como, além disso, se relacionam às conceituações greco-romanas, já que novamente aqui estão presentes os aspectos da ficcionalidade (história inventada) e de relato sucinto. Isso não necessariamente significa que as definições da fábula indiana se basearam nos conceitos greco-romanos, mas que, possivelmente, ambos “beberam da mesma fonte”, reforçando a hipótese da Mesopotâmia como ponto de partida para o que hoje é considerado como um gênero literário. Além disso, ainda é possível que as noções e os conceitos de um e de outro tenham se complementado e se assemelhado justamente nas trocas interculturais.

Segundo Aderson ${ }^{247}$, nos textos védicos - situados entre XX e X a.C. - é possível encontrar vestígios de utilização de animais muito próximos das estruturas fábulares, o que,

\footnotetext{
247 VARGAS, M. V. A. DE M. Do Pañcatantra a La Fontaine: tradição e permanencia da fábula. São Paulo: Universidade de São Paulo, 1990. 256 f. Tese (Doutorado em Filologia e Linguística Românica), Faculdade de Filosofia Letras e Ciências Humanas - FFLCH. Universidade de São Paulo, São Paulo, 1990.
} 
para ela, consiste em um argumento favorável ao fato de que já naquela época as fábulas eram correntes e, além disso:

\begin{abstract}
A tendência de aproximar o caráter e as ações humanas do comportamento animal garantia a existência de um sistema de caracteres animais, cada um investido de certa qualidade ou defeito humano: a raposa ardilosa, o cão fiel, o burro tolo etc. Essa tendência dificilmente poderia ser relacionada apenas a um determinado povo [...] mas devemos observar cuidadosamente as alegorias mais elaboradas como as do velho leão cansado de caçar que exige de cada espécie uma vítima para sua refeição diária, nas quais [...] há claramente a manifestação de uma existência já politizada. É muito fácil percebermos que esse leão representa um rei que vive dos tributos dos súditos. ${ }^{248} 1$
\end{abstract}

Não que as fábulas de Esopo não tivessem um caráter político, mas esse aspecto ainda não tinha sido mencionado como associado diretamente a elas e, em contrapartida, é exaltado no ramo indiano, já que o Pañcatantra, por exemplo, se baseia no Código de leis de Manu, e, com isso, se constitui como manual detentor de regras que se aplicam a várias matérias, entre elas a política e a administração.

Além do Pañcatantra, há uma série de narrativas indianas inclusive anteriores a ele em que já é possível reconhecer elementos característicos das fábulas, como a existência de animais antropomorfizados e o uso de discurso direto. Apesar disso, não havia ainda a noção de fábula enquanto gênero literário, assim como não a encontramos nem na Grécia, nem muito menos entre os romanos. Podemos verificar também no Mahãbhãrata a recorrência de diversas marcas das fábulas, como o encadeamento de narrativas por encaixes - estrutura que provavelmente tem suas origens na Índia - por meio da oralidade, que ainda atribui ao discurso efeitos de veracidade, posto que, ao enunciar que “sábios disseram algo”, busca-se, nesse recurso, sugerir que algo de fato fora dito (e não por qualquer um).

O Mahãbhãrata, por sinal, é um exemplar de purana (antiguidade), ou seja, é, segundo as classificações indianas, um compêndio de antigas lendas. Essas antigas lendas são recolhidas especialmente do patrimônio popular (que há pouco vimos ser desmerecido por Quintiliano). Além dos aspectos políticos e culturais observados até então na constituição da fábula indiana, não é possível estudá-la sem verificar mais atentamente a presença dos textos de conteúdo edificantes, pertencentes essencialmente - mas não unicamente - à literatura budista, denominados jātakas. Encontramos traços desses textos na composição do Pañcatantra, que em muito influenciam a estrutura: as máximas que abrem e fecham as narrativas (conforme 
estudaremos adiante mais detalhadamente, são denominadas promítio e epimítio) são espelho das composições religiosas existentes, inicialmente, nos jātakas ${ }^{249}$ e de caráter doutrinário.

Tão associada aos códigos de conduta e aos textos religiosos, a fábula em pouco se diferenciaria deles, adotando elementos compositivos de ambos. Para Aderson, é a “estruturação ‘em encaixes’ a marca principal que vai conferir às fábulas do Pañcatantra a categoria de gênero literário”250.

Também encontramos a estruturação em encaixes ou estrutura-em-cadeia nos fabulários árabes, que não negam a sua trajetória, por sinal. Os árabes entram em contato com a cultura indiana cedo, por meio de relações comerciais, e, invariavelmente, acabam por trocar saberes. Assim, não é incorreto dizer que as fábulas indianas são conhecidas entre os árabes antes de sua formalização nos fabulários, pois, voltamos a dizer, a oralidade, marca tão característica delas, é também o meio pela qual se propagam. É no saber popular que a fábula adquire substância e é na passagem entre povos que se disseminam, muito antes de serem acomodadas em compêndios ou conceituadas por estudiosos. Contudo, dizem as referências que o Kalīla e Dimna, fabulário basilar da cultura árabe, teria sido escrito através da tradução - não tão fiel de uma versão pehlevi do fabulário indiano Pañcatantra (como foi dito anteriormente, os persas, ao serem derrotados pelos povos árabes, tiveram seu patrimônio espoliado pelos vencedores). Não à toa observamos na obra árabe uma estruturação tão aproximada da indiana, embora tenha sido encarada, sob muitos aspectos, de modo diferenciado pelos críticos e estudiosos dessa cultura.

Embora ela seja bem antiga em árabe, e alguns estudiosos afirmem que já era corrente entre esses povos desde o período pré-islâmico ${ }^{251}$, foi pouco registrada em língua escrita (mantendo-se sobretudo na circulação por via oral), e o que temos de comprovadamente mais antigo é justamente o fabulário Kalīla e Dimna, posto que, embora existam outras obras às quais se aludiu uma origem, verificou-se que, historicamente, essas referências seriam equivocadas.

Tal como havia ocorrido entre os clássicos, a fábula (originalmente ḥurâfa no idioma, ou "mito”, “ficção”) desse período inicial de registro volta a passar por um processo de relativização e diminuição de importância no momento de sua propagação: muitos estudiosos,

\footnotetext{
${ }^{249}$ VARGAS, M. V. A. DE M. Do Pañcatantra a La Fontaine: tradição e permanencia da fábula. São Paulo: Universidade de São Paulo, 1990. 256 f. Tese (Doutorado em Filologia e Linguística Românica), Faculdade de Filosofia Letras e Ciências Humanas - FFLCH. Universidade de São Paulo, São Paulo, 1990, p. 47.

${ }^{250}$ Ibid., p. 42.

${ }^{251}$ Estudiosos árabes como Iḥsan cAbbās e cUmar Farrûh estão entre aqueles que afirmam a antiguidade da fábula árabe.
} 
devido ao caráter ficcional que ela detivera até o momento, desqualificam-na e consideram-na inferior a outras formas de produção. Destacamos a passagem a seguir para evidenciar o que dizemos:

Quando lhe perguntaram: 'Você se aborrece com histórias?’ Ḥâlid Bin Safwân respondeu: 'O que aborrece são as velharias [trocadilho com a palavra hadît, que pode significar tanto "história" como "novo"], pois as histórias são amadas pelos sentidos com o auxílio do intelecto, e é por isso que os meninos e as mulheres as apreciam'. [...] Por causa da imensa necessidade que se tem de tais histórias, nelas foram introduzidas coisas falsas, misturadas a absurdos e relacionadas ao que agrada e causa o riso, mas não provoca questionamentos nem investigações, a exemplo do livro Hazâr afsâna [Mil fábulas, conhecido como As mil e uma noites], e todas as espécies de hurâfat [fábulas] que entraram em livros desse gênero [...]”252

A próxima passagem também corrobora o exposto até então:

E entre as histórias inventadas e as notícias falsificadas e adornadas, estão o livro de Kalīla e Dimna e o livro Alqâ’if [fisionomista], de Abû Alcalâ Al-macarrî, no qual se fala na língua de animais, e de não animais [...] E Abû Al'alâ Al-macarrî levou a cabo, com o Livro do fisionomista, um benefício conhecido, e uma bem rica criação. Tem mais folhas que Kalīla e Dimna, é mais amplo, e cheira melhor, exalando mais fragrância. ${ }^{253}$

Como se pode observar, o livro de Kalīla e Dimna estava longe de ser agraciado pela crítica, embora seja notável o número de citações a ele. Em resposta a um livro que era de origem não muçulmana, muito se tentou fazer no sentido de reescrevê-lo e superá-lo (o que, para o bem ou para o mal, lhe atribui valor), e desse procedimento resultaram obras como o Livro do tigre e do raposo, em certos aspectos mais adequada ao islamismo ${ }^{254}$, mas, em contrapartida, de pouquíssima disseminação.

O último dos fabulários estudados, O leão e o chacal mergulhador, situa-se em uma linha fronteiriça entre o que entendemos como fabulário e o que é definido pela crítica moderna como “espelho de príncipe” ou “literatura sultanesca”. Há, na literatura árabe, um sem número de obras que recebe essa definição e elas têm como objetivo ensinar "ao poderoso as tradições do exercício do poder, e as políticas que criam tradição de poder e governo, facilitando ao líder a condução das questões ligadas ao poder, bem como a sua preservação em suas mãos pelo maior período possível”255. É interessante observar que, já no primeiro fabulário que consta da tradição árabe o caráter político se mostrava muito ressaltado, mas, nem por isso, ele era

\footnotetext{
${ }^{252}$ In. ATTAWHÎDÎ, A. H. Deleitamento e Afabilidade, Edição do Cairo, v. 1, 1953, p.23, apud JAROUCHE, 2009.

${ }^{253}$ ANÔNIMO. O leão e o chacal Mergulhador. Tradução de Mamede Mustafa Jarouche. São Paulo: Editora Globo, 2009, p. 204.

${ }^{254} \mathrm{O}$ Livro do tigre e do raposo se adequava melhor ao islamismo por apresentar uma série de alusões a religião e mesmo citações diretas a poetas de renome. Além disso, ele era bastante reduzido em relação ao seu antecessor, aparentemente em um processo de "limpeza", que deixava apenas o que era essencial. Curiosamente todos esses procedimentos não resultaram em um sucesso, pois, ao que se tem de notícias, nem na época o livro teve ampla circulação.

${ }^{255}$ Alhaddad apud Jarouche, 2009.
} 
considerado pelos críticos como uma unânime ferramenta para obtenção e manutenção de poder, o que nos leva a questionar: o que mudou na recepção das obras ou nas estruturas dos fabulários que resultou em uma nova designação e também em uma valoração do procedimento?

No que se refere aos espelhos de príncipe, é possível dizer que a tarefa de definir os specula principum se revela mais árdua do que poder-se-ia imaginar inicialmente, devido à amplitude de definições realizadas acerca desse gênero. Em sua forma mais ampla, todos os estudos parecem apontar em uma direção - são trabalhos de caráter educativo, que visam à formação adequada de um futuro governante para o melhor exercício de sua função. O problema surge, porém, na tentativa de restringir as obras que atingem estes pré-requisitos, pois, entre elas, podem figurar desde tratados de moral religiosa até obras ficcionais que abordem o tema político, posto que tenham como público almejado os governantes ou aqueles que lidarão com as vicissitudes do poder. Notam-se, então, diferenças relevantes entre os textos considerados por diferentes autores como espelhos de príncipe, tanto no aspecto do tipo de ensinamento que se pretende passar - sejam os conselhos políticos práticos e amorais (ou, no mínimo, pertencentes a uma moral que difere da corrente) de O Príncipe, de Maquiavel (século XVI d.C.), até os ensinamentos cristãos de textos como o Cidade de Deus, de Santo Agostinho (século V d.C.) -, quanto na forma que toma a obra, podendo, segundo a concepção de alguns ${ }^{256}$ incluir tanto textos de caráter ficcional, desde que tratem a temática do poder, até os tratados dedicados diretamente a um ou outro reinante.

Dentro dessa concepção expandida, se encontrariam como figurantes do gênero de espelho de príncipe todos os fabulários tratados neste mestrado, mas consideramos a definição anacrônica por ser posterior a algumas das obras e, portanto, não a aplicamos dessa maneira. Esta, porém, não é a única forma possível de se conceber os specula principum. Vários autores, segundo Muniz ${ }^{257}$, limitam o gênero a obras desprovidas de características ficcionais.

Na impossibilidade de dar maiores definições do que seriam os espelhos de príncipe, deixamos aqui uma passagem que, se não define o gênero, nos proporciona um vislumbre do

\footnotetext{
${ }^{256}$ Assim como a concepção de Nair de Nazaré Castro Soares, apresentada por MUNIZ, M. R. C. em O Leal Conselheiro e a tradição do espelho de príncipe: considerações sobre o gênero. In: PARRILLA, Carmen (org.). Actas del IX Congresso Internacional de La Asociación Hispánica de Literatura Medieval. Noia: Toxo Soutos. V.2. pp. 89-103.

${ }^{257}$ MUNIZ, M. R. C. O Leal Conselheiro e a tradição do espelho de príncipe: considerações sobre o gênero. In: PARRILLA, Carmen (org.). Actas del IX Congresso Internacional de La Asociación Hispánica de Literatura Medieval. Noia: Toxo Soutos. V.2. p. 89-103.
} 
que ele seria na cultura árabe: “quem aconselha o soberano não lhe deve ocultar o conselho, ainda que este o desdenhe; e que as suas palavras ao soberano sejam delicadas, e não invasivas, até deixa-lo a par de seus defeitos [...]”258.

Podemos perceber mais uma bifurcação a partir do que tínhamos inicialmente: ao mesmo tempo em que os espelhos de príncipe passam a se desenvolver com características próprias e chegam a ter ampla circulação no medievo ${ }^{259}$, por outro lado, também as fábulas que se estruturam sem esse viés do endereçamento direto aos potentados se desenvolvem em um caminho que será bastante profícuo, no qual inserimos exemplos como O livro das mil e uma noites e Sindabâd (ou Os sete vizires); não se trata de dizer que não há conteúdo político nessas fábulas ${ }^{260}$, mas sim que elas se desenvolvem em uma estrutura elaborada trazendo aspectos tais que as associam mais ao que muitos autores entendem como um precursor dos contos de fadas $^{261}$.

Apontamos agora uma passagem que segue corroborando esses caminhos:

Quem primeiro produziu fábulas, e as pôs em livros, e guardou [tais livros] em bibliotecas, e compôs uma parte disso na linguagem de animais, foram os persas; a seguir, aprofundaram-se nisso os reis aṣgânidas, terceira geração dos reis persas. Depois, semelhantes fábulas se difundiram e ampliaram na época dos reis sassânidas, e então os árabes as passaram para o seu idioma, e os eloquentes e disertos poliram-na e ornamentaram-nas, elaborando, no mesmo sentido, fábulas equivalentes. O primeiro livro feito nesse sentido foi Hazâr afsâna, que significa “mil fábulas". ${ }^{262}$

Conforme pudemos perceber na tentativa de levantamento sobre as origens e definições acerca da fábula, alguns elementos aparecem com importante recorrência, mas, em compensação, é notável a falta de um deles: nenhuma das culturas e momentos históricos assinalados até então havia se preocupado em definir a fábula enquanto gênero, e, pelo contrário, como podemos observar em Aristóteles, ela era antes uma figura retórica que podia ser utilizada de acordo com a finalidade do orador, sem que se sustentasse per si.

\footnotetext{
258 Anuwayri Nihayat alarab fi funum aladab. “O extremo da inteligência nas artes do decoro”. Cairo, s.d., v.6. Apud Jarouche, 2009.

${ }^{259}$ MUNIZ, M. R. C. em O Leal Conselheiro e a tradição do espelho de príncipe: considerações sobre o gênero. In: PARRILLA, Carmen (org.). Actas del IX Congresso Internacional de La Asociación Hispánica de Literatura Medieval. Noia: Toxo Soutos.

260 Muito pelo contrário, aparentemente a política é um traço bastante presente no fabulário árabe, e, mesmo quando não explicitada, se apresenta: em ambos os fabulários mencionados é possível verificar em maior ou menor grau um panorama essencialmente político e de relações de poder e de hierarquia (diríamos inclusive que, em última instância, ambos tratam das relações entre poder e saber), mas é possível verificar que se desenvolvem em caminhos sutilmente diferentes daqueles trilhados pelos espelhos de príncipe.

${ }^{261}$ O livro das mil e uma noites é considerado amplamente, e principalmente a partir da conceituação de Todorov, um exemplo de coletânea de contos maravilhosos.

${ }^{262}$ Annadîm Awarrâq apud Jarouche, 2005, v. I., pp. 15-16.
} 
Seguindo na mesma linha que mantivemos até o momento, Perry situa três etapas na história literária da fábula antiga, que expomos a seguir:

\begin{abstract}
The literary history of the fable in ancient times is marked by three successive periods of development, each of them conditioned by a different outlook on the part of the authors concerned. In the earliest period fables are related by Greek writers only incidentally, either with reference to a specific situation, when the telling of the tale is represented as an act of Aesop or of someone else, or as the author's own illustration of an idea that he is seeking to convey. In other words, the written fable in classical times exists only in a context and is not told as an end in itself. Naturally this use of fable was never abandoned, but was as common in later antiquity as ever before or since. In classical times, however, this was almost the only way in which an Aesopic fable would find its way into literature. In the second period of fable-writing, which corresponds roughly with the Alexandrian age, fables were gathered into collections by scholarly compilers for the convenience of writers and speakers who would use them in the same way in which earlier writers had used them, i. e., as occasional illustrations in a speech or an essay. It was not until the third period, ushered in by Pahedrus and Babrius (or shortly before), that the compilers of fable-collections came to regard their productions, even when written in prose, as to some extent literature in its own right, as something to be read for its own sake rather than to be used merely for reference. ${ }^{263}$
\end{abstract}

Embora, tal como nos expõe a passagem, possamos perceber que de fato há uma mudança na forma de encarar a fábula, e ela passe a ser utilizada não apenas como estratégia de argumentação, mas como uma narrativa que se sustenta por si só - assim como verificamos principalmente no ramo indiano e, tardiamente, no ramo clássico - ainda assim não encontramos muito que se diga a respeito de uma definição ou categorização, e a noção de gênero que invariavelmente aplicamos a ela é deveras posterior.

Então, assim como fizeram outros autores, nos apoiaremos agora em Todorov com o objetivo de tecer algumas ideias sobre o conceito de gênero literário, posto que entendemos a fábula como um. O autor adentra essa conceituação com adequada precaução, considerando diversos matizes e suas problematizações antes de definir o que é, para ele, gênero. Entre outras discussões bastante pertinentes que proporciona ao leitor, debate a necessidade de uma norma, de uma estrutura, inclusive para que ela possa ser extrapolada, transgredida, e para que essa transgressão produza efeitos na leitura. Apoiado em Genette, que diz que “o discurso literário se produz e se desenvolve segundo estruturas que só pode transgredir porque as encontra, ainda hoje, no campo de sua linguagem e de sua escritura”264, mantém seu argumento e, em um devir que em muito se assemelha ao que viemos desenvolvendo até então, diz que “de uma maneira mais geral, não reconhecer a existência de gêneros equivale a supor que a obra literária não

${ }^{263}$ PERRY, B. E. The Origin of the Epimythium. Transactions and Proceedings of the American Philological Association, 1940, v. 71 p. 392.

${ }^{264}$ Genette, G. Figures II, p. 15 apud Todorov, 2010, p.12. 
mantém relações com as obras já existentes”265. Assim, considerando essas relações que se estabelecem entre obras de contextos diferentes, culturas e tempos diferentes, passa a postular sobre traços distintivos que, aparentes em cada uma delas, situam-se, no entanto, “a um nível abstrato, independente das obras existentes. Deveria ser dito que uma obra manifesta tal gênero, não que ele exista nesta obra”266, portanto.

Realizadas essas devidas pontuações, define-se gênero, de acordo com o autor, como um ato de fala institucionalizado, com base no que segue: "numa sociedade, institucionaliza-se a recorrência de certas propriedades discursivas, e os textos individuais são produzidos e percebidos em relação à norma que esta codificação constitui. Um gênero, literário ou não, nada mais é do que essa codificação de propriedades discursivas”267.

Trazemos a esse momento de conceituação a interessante passagem de Frye, que versa sobre a retórica:

\footnotetext{
A retórica, desde o início, significou duas coisas, discurso ornamental e discurso persuasivo. Essas duas coisas parecem psicologicamente opostas uma à outra, como o desejo por ornamento é essencialmente desinteressado, e o desejo de persuadir essencialmente o oposto. De fato, a retórica ornamental é inseparável da literatura, ou o que chamamos de estrutura verbal hipotética, cuja existência é autojustificada. A retórica persuasiva é literatura aplicada, ou o uso da arte literária para reforçar o poder de argumentação. [...] a retórica persuasiva procura levá-los cineticamente a um percurso de ação. ${ }^{268}$
}

Com base no exposto, passamos agora a tentar traçar possíveis definições do que consideramos, nas obras estudadas, manifestações do que entendemos como um gênero. Verificamos nos quatro livros que utilizamos como recorte ${ }^{269}$ algumas recorrências, conforme demonstramos ao longo de todo o trabalho, e as resumimos nos seguintes traços compositivos: um exaltado aspecto pragmático (narrativas mobilizadas por ações); caráter ficcional; existência de uma moral que perpassa e condiciona as narrativas; utilização de personagenstipo (não necessariamente animais antropomorfizados) submetidos à ação e a moral que se pretende elaborar; a persuasão como intenção.

\section{Apontamentos diversos sobre os fabulários}

\section{Estrutura}

\footnotetext{
${ }^{265}$ TODOROV. T. Introdução à literatura fantástica. São Paulo: Editora Perspectiva, 2010, p.12.

266 Ibid., p. 26.

267 TODOROV, T. Os gêneros do discurso. São Paulo: Martins Fontes, 1980. p. 48.

${ }^{268}$ FRYE. N. Anatomia da crítica - quatro ensaios. São Paulo: Realizações Editora, 2014. pp.391-392.

${ }^{269}$ Pañcatantra, Kalīla e Dimna, O livro do tigre e do raposo e O leão e o chacal Mergulhador.
} 
Segundo Dezotti ${ }^{270}$, toda fábula esópica “se organiza em dois parágrafos: no primeiro, está a narrativa, e, no segundo, o epimítio, assim chamado pelos retores antigos justamente porque vem depois da narrativa (mythos)”. Esse epimítio seria justamente o espaço para a apresentação da moral, por meio da presença de um texto metalinguístico representado em "a fábula mostra”. A organização das fábulas de Esopo seguiria então uma estrutura cristalizada, na qual tanto o mito quanto o epimítio teriam igual importância.

A mesma autora ainda declara a passagem que segue, e, a partir dela, teceremos alguns comentários:

Deve-se, portanto, considerar a fábula esópica anônima como documento de um estágio da
historia da fábula em que ela já se encontrava fixada como um gênero discursivo composto de
texto narrativo acompanhado de epimítio. Afinal, o estilo formular e as construções elípticas
constituem provas decisivas de que o epimítio esteve, necessariamente, sempre presente, como
seu componente integrante e fundador, no processo de fixação da fábula como gênero literário.

Após termos entrado em contato com as narrativas indianas e árabes, podemos afirmar que, se houve momentos em que a fábula se constituiu da maneira como a autora afirma, o que se manteve enquanto traço distintivo de gênero não foi necessariamente a disposição das partes - mito e, em seguida, epimítio -, mas sim a coexistência necessária de duas partes - mito e moral -, que necessariamente precisam estar juntas, independentemente de uma ordem, para que a fábula seja reconhecida. Dizemos isso com base nas estruturas que estudamos e que apontamos adiante. Além disso, vale apontar que, embora a autora se refira a uma fixação da fábula enquanto gênero discursivo, podemos dizer, com base no que estudamos e apresentamos até o momento, essa fixação se refere mais a um uso estruturado (a um modo de fazer) que a uma conceituação teórica, tendo em vista principalmente o que pudemos depreender de Aristóteles em sua Retórica.

As narrativas indianas, conforme podemos sugerir com base no contato entre culturas já apresentado previamente na contextualização histórica - não se desenvolveram desligadas ou à parte da produção literária grega, sendo, pelo contrário, influenciadas em muitos aspectos por ela. Contudo, o contato com esses conhecimentos não resultou em uma simples reprodução, mas sim em uma apropriação que leva em conta, segundo as nossas hipóteses, características

\footnotetext{
${ }^{270}$ DEZOTTI, Maria Celeste Consolin. A fábula grega: da prática discursiva a gênero literário. Revista Organon. [on-line], v.13, n. 27. Porto Alegre: UFRGS, 1999, julho-dezembro 1999. Disponível na Internet: < http://seer.ufrgs.br/organon/article/view/30429/18870 >, ISSN 2238-8915.
} 
históricas e culturais dos povos. Assim, apontamos uma fábula indiana para, em seguida, fazermos a contraposição dessas estruturas:

$[\ldots]$

- Tolo! Eu lhe disse que a maré do oceano removeria os ovos e que devíamos mudar-nos para mais longe. Porém, refugiando-se na vaidade, por ignorância, você não fez caso do que previ. Há um modo mais adequado de dizer isso:

Quem não faz caso da palavra dos amigos que desejem o seu bem morre como a tartaruga que caiu do bastão.

- O tittiba perguntou:

- Como foi isso?

Ela contou:

[Fábula XIII A tartaruga Kambugriva] Em um certo lago, vivia uma tartaruga chamada Kambugriva, que tinha dois amigos da família dos cisnes, chamados Samkata e Vikata, unidos por imensa amizade. Os dois cisnes encontravam-se com ela nas margens do lago, para contar histórias de vários dervasi e maharsi e retornavam ao seu ninho na hora do sol poente. Com o passar do tempo, o lago foi secando pouco a pouco devido à falta de chuva. Aflitos com a calamidade, eles disseram:

- Ó amiga, este lago tornou-se pura lama. Como você poderá viver? A ansiedade tomou conta de nossos corações.

Ouvindo isso, Kambugriva disse:

- Deveras! Pela falta d’água, agora já não temos possibilidade de viver. Por isso, devemos pensar num expediente, pois se diz:

A perseverança não deve ser abandonada mesmo em época adversa: pela perseverança, às vezes, encontra-se refúgio, assim como um mercador, mesmo numa embarcação danificada e no meio do oceano, ainda deseja atravessá-lo.

- Além disso:

Manu disse estas palavras: Pelo bem do amigo e pelo bem da família, o sábio sempre persevera com energia, quando as calamidades acontecem.

- Tragam, então, uma corda forte ou um bastão leve e procurem uma lagoa com bastante água. Eu agarrarei, com os dentes, no meio do bastão e vocês, nas pontas. Depois de agarrarmos todos juntos, vocês me levarão até essa lagoa.

Eles disseram:

- Amiga, assim faremos, porém você deve permanecer em voto de silêncio, senão cairá do bastão. Assim feito, quando viajava, Kambugriva avistou uma cidade situada lá em baixo. Os habitantes, vendo-a ser conduzida daquela forma, assombrados, disseram:

- Nossa! Algum objeto arredondado é levado pelos dois pássaros!

Ouvindo o barulho deles, Kambugriva disse:

- Ei! O que é esta zoeira?

Assim tinha em mente falar, mas caiu na metade da frase e foi feita em pedacinhos pelos habitantes da cidade. Por isso eu digo:

Quem não faz caso da palavra dos amigos que desejem o seu bem morre como a tartaruga que caiu do bastão. ${ }^{271}$

Conforme é possível afirmar com base no exposto, a fábula indiana é enunciada por uma moral: “Quem não faz caso da palavra dos amigos que desejem o seu bem morre como a tartaruga que caiu do bastão”, e seguida pela pergunta “Como foi isso?”, que autoriza a passagem do mito. Após ele, a narrativa é finalizada com o uso da moral inicial, em uma repetição que tem aparente função reforçadora. Ou seja, a moral cerca o mito na estrutura

${ }^{271}$ ANÔNIMO. A tartaruga Kambugriva. In: Pañcatantra: Fábulas Indianas - Livro I. Tradução de Maria da Graça Tesheimer; Maria Valíria Aderson de Mello Vargas; Marianne Erps Fleming. 2. Ed. São Paulo: Humanitas, 2004, p. 171. 
indiana, precedendo-o e encerrando-o. Isso influencia diretamente na disposição e no desenvolvimento da fábula, e ocorre porque, diferente de Esopo, os indianos aplicavam a estrutura-em-cadeia. Enquanto a fábula do autor grego apresentava uma estrutura simples em que ela se justifica per si, com a apresentação do mito e a sua moral, a indiana recorre à uma série de procedimentos que estão diretamente atrelados à sua produção literária, política e religiosa $^{272}$. Nenhuma fábula está inserida nos cinco livros sem que se atrele a uma justificativa prévia, sem que se dirija a um interlocutor - por vezes inserido na obra - que a tenha solicitado e, consequentemente, autorizado. Assim, mesmo a constituição dos livros tem uma justificativa prévia - o ensino dos príncipes e de todos aqueles que precisam aprender muito em pouco tempo - e, a cada fabulário, uma narrativa introdutória se estabelece, justificando o que virá a seguir.

Assim, podemos aproximar a fábula indiana não apenas de Esopo - asseguradas as suas particularidades -, mas também de Hesíodo, que, ainda segundo a mencionada autora, seria o primeiro exemplo de autor a empregar a fábula aplicada a uma situação - tal como ocorre no Pañcatantra - e, consequentemente, introduziria a noção de promítio à constituição do gênero ${ }^{273}$. Podemos apontar então, na obra indiana, a existência de promítio, narrativa (mythos) e epimítio, caso apliquemos os termos correntes já em Aristóteles.

Ainda sobre esse recurso e a sua utilização no Pañcatantra, apresentamos a seguinte passagem, de Aderson:

Esses promítios e epimítios são instrumentos que engendram as histórias. No corpo dessa narrativa [...] há a enunciação de vários preceitos de conduta previstos nos códigos de leis e de comportamento em geral, sempre presentes nos textos, como pudemos observar, desde suas manifestações mais antigas. ${ }^{274}$

A fábula indiana exposta foi escolhida aleatoriamente, pois o procedimento de construção da narrativa se opera invariavelmente ao longo de todos os cinco livros que compõem o Pañcatantra. Por sorte, há uma fábula similar árabe presente no Kalīla e Dimna, que apresentaremos agora para, novamente, apontar peculiaridades de produção e de estruturação:

\footnotetext{
272 A fábula indiana se baseia tanto em tratados de conduta como de política para elaborar muitos de seus ensinamentos, conforme fora dito anteriormente. Assim, se basearia também em textos e procedimentos próprios e já validados pelos usos e transmissões que, por isso, não eram apartados dessa produção.

${ }^{273}$ Embora a autora reconheça esse procedimento, ela declara que "é a tradição esópica que tende a dominar na fábula ocidental”.

${ }^{274}$ VARGAS, M. V. A. DE M. Do Pañcatantra a La Fontaine: tradição e permanencia da fábula. São Paulo: Universidade de São Paulo, 1990. 256 f. Tese (Doutorado em Filologia e Linguística Românica), Faculdade de Filosofia Letras e Ciências Humanas - FFLCH. Universidade de São Paulo, São Paulo, 1990, p. 49.
} 
[...] Quando viu as coisas nesse estado, ela disse: “quem não ouve as palavras benéficas dos amigos sofrerá o que sofreu a tartaruga”. Ele perguntou: “e como foi isso?” Ela disse:

Contasse que em certa fonte viviam dois patos e uma tartaruga, os quais se tinham acostumado uns aos outros e se tornado amigos. Mas um dia a água da fonte começou a escassear fortemente em alguns períodos. Ao perceberem aquilo, os patos disseram: "somos obrigados a abandonar o lugar em que estamos e nos mudar para outro". Despediram-se da tartaruga dizendo: "fica em paz, que nós estamos indo embora daqui”. Respondeu a tartaruga: “mas a falta de água me é penosa; não posso viver sem ela; dai um jeito para que eu me vá convosco”. Disseram os patos: "somente poderemos fazer isso contigo se aceitares a condição de que, quando estivermos te transportando e alguém te vir e fizer comentários, não respondas”. Disse a tartaruga: “sim; mas como ireis me transportar?” Disseram os patos: “morderás um pedaço de pau bem no meio, e cada um de nós carregará uma ponta”. A tartaruga aceitou aquilo e eles voaram com ela. Os homens então a viram e disseram uns aos outros: "vede que assombroso! Uma tartaruga entre dois patos a carregarem-na no ar!” Ao ouvir aquilo, a tartaruga disse: "para desgosto de vós todos!” Porém, quando abriu a boca para falar, despencou em direção ao solo e morreu. ${ }^{275}$

Embora a fábula apresente, de modo geral, uma história e um desenvolvimento próximos da indiana, podemos verificar na leitura uma diferença: não há moral após a narrativa, ou seja, não consta nesta fábula o epimítio, apenas o promítio "quem não ouve as palavras benéficas dos amigos sofrerá o que sofreu a tartaruga”, seguido da narrativa (mythos). Novamente associamos essa diferença a uma estratégia que evidencia uma apropriação e uma assimilação, que se relaciona aos elementos culturais da cultura árabe daquele período específico. Inseridas em uma narrativa principal, as subnarrativas eram, para efeitos discursivos, inseridas na obra mediante a apresentação de uma moral para qual um interlocutor solicitava uma explicação, um “e como foi isso?”; partindo daí e apartado de manuais que orientassem ou delimitassem seus procedimentos - não apenas apartado, aliás, mas ansioso por apagá-lo -, o Kalīla e Dimna não precisava se ater à repetições e, por conta disso mesmo, apresentava-se de forma mais fluida.

Das variações entre uma fábula e outra, e ainda em relação às gregas, mantemos elementos que acreditamos ser essenciais para a constituição da fábula enquanto gênero: mito e moral, não necessariamente submetidos a uma ordem ou hierarquia.

Devemos nos perguntar agora se os outros fabulários árabes estudados neste trabalho corroboram a ideia. Ao buscarmos esses elementos no Livro do tigre e do raposo, nos deparamos com uma questão: como o texto é desprovido de subnarrativas, ao menos quanto a esse aspecto somos forçados a recorrer apenas à estrutura maior, e única, em que se desenvolve

\footnotetext{
${ }^{275}$ IBN ALMUQAFFA ${ }^{\mathrm{C}}$, Kalila e Dimna. Tradução, organização, introdução e notas de Mamede Mustafa Jarouche. São Paulo: Biblioteca Martins Fontes, 2005, p. 81.
} 
a história. Iniciado por uma narrativa que situa o raposo, delineia uma moral inicial e, novamente, ao cabo da obra, não há a necessidade de reforça-la.

Já o fabulário híbrido de espelho de príncipe O leão e o chacal Mergulhador mantém a estrutura de Kalīla e Dimna e traz, em suas subnarrativas, promítios, tal como segue:

[...] Eu te aviso, meu irmão, de que teu empenho no dever poderá exceder-se, e então teu paradigma será o mesmo que o do falcão e da perdiz. O Mergulhador perguntou: "E como foi, meu irmão, o caso deles?”. O amigo respondeu:

[O falcão e a perdiz] Conta-se que certo sátrapa foi até um príncipe de Hurasan levando um falcão e uma perdiz, e disse: "Ó príncipe, passei por um bosque, ateei fogo numa de suas bordas e esta perdiz saiu voando; então enviei meu falcão para pegá-la, e ele lhe seguiu no encalço; ela se manteve em fuga até que o forte medo a fez cair no fogo; o falcão precipitou-se em seu rastro e se queimaram ambos. Então, eu tos trouxe a fim de que vejas as consequências do empenho no dever e da covardia". ${ }^{276}$

Há uma exortação inicial, em que o amigo do Mergulhador o alerta para um fato e busca, assim, dissuadi-lo de seu intento, a qual segue a alusão a uma situação paradigmática. Tal como nas estruturas anteriormente observadas, verificamos que o Mergulhador solicita então que o paradigma seja exposto: “E como foi, meu irmão, o caso deles?”, e assim, entramos em contato com a subnarrativa. Há, inegavelmente, uma moral que perpassa a fábula, mas que, notavelmente, se modificou ao longo dos tempos e das culturas. Se inicialmente os intentos, as morais e as justificativas necessariamente se apresentavam mais claros, no decorrer dos tempos e na disseminação das fábulas por entre as culturas - ao menos entre as mencionadas neste estudo -, esses traços foram se amainando, deixando de ser tão necessários porque, talvez, já estivessem internalizados. Tendo a fábula como um gênero corrente, certos elementos passavam a ser de conhecimento geral e, possivelmente por isso, não precisassem ser exaltados na estrutura: caí então, ao menos nesse ramo ${ }^{277}$, a necessidade de uma moral tão manifesta.

De todo modo, podemos reforçar, acerca da moral, o que havíamos dito anteriormente: tanto o compêndio indiano como os fabulários árabes seguem o mesmo procedimento e associam mito e moral, independentemente da ordem na qual dispõem esses elementos, em um proceder didático.

Ao detalharmos esses procedimentos, pudemos também evidenciar um outro importante traço compositivo dos fabulários estudados: ambos se utilizam da mesma estratégia, "e como foi isso?” no Pañcatantra e "E como foi, meu irmão, o caso deles?”, no livro de Kalīla e

${ }^{276}$ ANÔNIMO. O leão e o chacal Mergulhador. Tradução de Mamede Mustafa Jarouche. São Paulo: Editora Globo, 2009, p. 33.

${ }^{277}$ Nos referimos a um ramo que compreende fabulários indianos e árabes porque verificamos que a tradição que se apoiou nos fabulários greco-romanos manteve essa estrutura de uma forma mais cristalizada, inclusive quanto à moral: ela permaneceu bastante clara em fabulários de caracterização “esópica”, por exemplo. 
$\operatorname{Dimna}^{278}$, para atingir o mesmo propósito: originar narrativas que vão se inserindo, seguidamente, umas nas outras, de forma a "se encaixarem". Segundo Schaeffer ${ }^{279}$, esse mecanismo de encaixamento seria genuinamente oriental, assim como a narrativa-quadro, que contém as diversas subnarrativas em encaixe. As expressões utilizadas para gerar os diversos níveis de desenvolvimento de narrativas (ou fábulas encaixadas umas nas outras) seriam evidências da tentativa de suprir uma enunciação real e reproduzi-la, tanto quanto possível, na estrutura do fabulário, além de ressaltar o aspecto narrativo da fábula.

\section{Traduções, versões e apagamentos - sobre narrativas e soberanos}

Falaremos um pouco agora sobre a tradição da tradução de textos a mando de reis, califas e demais governantes e como ela, segundo Kinoshita ${ }^{280}$, se articula com a construção e manutenção do poder e seus símbolos. Ele aponta uma relação entre o conceito medieval de translatio imperii, segundo o qual o poder (e a legitimidade) imperial sofre uma transferência natural após a decadência de um império, e o conceito de translatio studii, que descreve a transferência ou tradução da sabedoria de uma cultura a outra ${ }^{281}$. Para o autor, um governo que tenta firmar seu poder ou legitimidade muitas vezes se valerá da tradução de obras de outra cultura - seja um império cujo poder, em seu período, foi incontestado, seja a cultura de uma região recém-conquistada - como forma de apontar uma continuidade entre a cultura que produziu aquela obra e a cultura que a traduz. Além de construir uma imagem de herança cultural com aquela cultura e, portanto, justificar sua presença no território que ela ocupa ou a assimilação de traços da imagem daquela cultura - aqui pode-se destacar as traduções de obras árabes feitas no reino de Castela, com o objetivo de tornar o castelhano a língua dos saberes das ciências naturais e, assim, trazer prestígio ao reino ${ }^{282}$ - a tradução das obras de uma cultura e a assimilação de seus carácteres culturais significa também a criação de, citando Kinoshita, “[...]

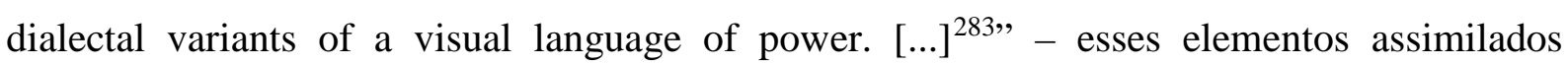

\footnotetext{
${ }^{278}$ No fabulário árabe há pequenas variações em cima dessa pergunta, mas, apesar delas, mantém-se a mesma estrutura: uma subnarrativa só se insere após esse pedido/autorização.

${ }^{279}$ Apud Aderson, 1990, p.27.

${ }^{280}$ KINOSHITA, S. Translatio/n, empire, and the worlding of medieval literature: the travels of Kalīla wa Dimna. Postcolonial Studies, v. 11, n. 4, p. 371-385, 1 dez. 2008. pp. 374-375.

${ }^{281}$ Ibid., p. 371

282 Ibid., p. 377.

${ }^{283}$ KINOSHITA, S. Translatio/n, empire, and the worlding of medieval literature: the travels of Kalīla wa Dimna. Postcolonial Studies, v. 11, n. 4, p. 371-385, 1 dez. 2008. p. 375.
} 
resultariam, portanto, no enriquecimento da linguagem do poder de um governo ou, se não enriquecimento, ao menos a adequação ao contexto no qual se insere.

Outro elemento referente à cultura de tradução, que tem ramificações especialmente interessantes a este mestrado - por também envolver a relação entre poder e saber - é a recorrência, tanto nos prefácios dos manuscritos quanto em suas ilustrações, da figura de um letrado que dedica ou presenteia a tradução da obra ao rei que a encomendou. Neles estão presentes elementos da relação dos sábios com os detentores do poder, da legitimação do poder pelo saber e da natureza dos poderosos como uma figura distinta da dos sábios.

Apontamos que, dentre os exemplos citados pelo autor em seu texto, a dinastia dos abássidas, período no qual foi elaborado o Kalīla e Dimna - mais especificamente, no momento de sua acenssão -, é citada como um dos exemplos mais bem-sucedidos e elaborados do uso da translatio studii para a legitimação do poder: os califas abássidas incorporaram à sua civilização elementos da ideologia e astrologia zoroastra, assim como tentaram tomar para si a imagem de colecionadores do conhecimento com a qual os reis sassânidas se revestiam outrora. ${ }^{284} \mathrm{O}$ livro de Kalīla e Dimna, que se apresenta como uma tradução da versão pehlevi do Pañcatantra - e o capítulo do médico Burzuwayh, em especial - pode, portanto, ser compreendido como mais uma forma de remeter-se a esta tradição persa e, com isso, firmar seu poder na região conquistada.

Essa leitura vem ao encontro de nossos apontamentos, pois, ao longo da análise dos dois mencionados fabulários, nos capítulos I e II desta dissertação, pudemos traçar hipóteses justamente a respeito das assimilações, subversões e apagamentos que o livro de Kalīla e Dimna apresentava em relação ao fabulário indiano, no evidenciar de um procedimento que, segundo Kinoshita, estava embasado em uma tradição de supressão das culturas subjugadas e na apropriação de seus elementos, em consonância com aquilo que a cultura dominadora traria consigo.

\section{Por quê e por quem: o que ainda se pode dizer dos fabulários?}


Afora todos os aspectos que são unanimemente levantados e estudados pelos autores que se dispõem a falar sobre a fábula ${ }^{285}$, pretendemos, para encerrar as discussões entabuladas ao longo deste trabalho, abordar brevemente algo que surge como reflexo de nossas leituras e apontamentos; além dos propósitos moralizantes e persuasivos que percebemos, indubitavelmente, na fábula, há outro intento que se pôde vislumbrar: a manutenção e validação das posições hierárquicas, quase como em um elogio aos potentados. Conforme pudemos perceber no decorrer deste trabalho, se estabelece, na maioria das narrativas de pano de fundo político, uma construção que não apenas valoriza o soberano como aponta para a necessidade de mantê-lo em sua posição e aconselhá-lo de modo adequado, para que ele não cometa erros e conduza seu reino da maneira mais adequada possível.

Com base nisso, somos levados a elaborar a hipótese de que ao menos essas fábulas seriam necessariamente produzidas por aqueles que tivessem conhecimento dos diversos liames que envolvem as relações dos reis e dos impérios, ou, como disse Jarouche acerca do desconhecido autor de O leão e o chacal Mergulhador: "fica evidente que o autor, cujo nome não chegou a nossos dias, estava profundamente imerso na discussão política travada por todo o orbe islâmico, além de nutrido pela tradição literária e poética árabe, bem como por sua historiografia [...]”286; tanto ele como os demais autores de fábulas como as abordadas nesse trabalho precisavam deter certos conhecimentos que ficavam, necessariamente, restritos, não eram de acesso geral.

Pautamos e reforçamos essa inferência com base na constante verificação do detalhamento profundo e acertado das relações travadas entre aqueles que ocupavam a posição de poder e aqueles que, ao seu redor, ocupavam as posições de subalternos. Tal dinâmica pode ser observada, sem erro, em todas as obras abarcadas pelo nosso estudo, das quais é possível se retirar, minimamente, uma fábula que aborde esse tema de cada uma delas.

Considerando o fato de que os fabulários alcançavam, de modo geral, ampla circulação - tanto pela oralidade como pelo acesso aos registros escritos - entre as mais diversas camadas das sociedades, inclusive as que Quintiliano chamara de “do campo” e “ignorantes”, sugerimos

\footnotetext{
${ }^{285}$ A saber: existência de uma moral, presença de animais humanizados/antropomorfizados, aspecto narrativo (preocupação em contar uma história), finalidade persuasiva/instrumento de retórica, caráter ficcional, mentiroso e de invenção, inventivo acerca dos fatos que se narra.

${ }^{286}$ ANÔNIMO. O leão e o chacal Mergulhador. Tradução de Mamede Mustafa Jarouche. São Paulo: Editora Globo, 2009, p. 195.
} 
então a possibilidade de que essas fábulas tenham sido elaboradas propositadamente, almejando, assim, disseminar o que seria um conceito de reinado.

Assim, foi possível observar, em cada uma das obras, elementos que, em uma relação e obedecendo a traços gerais do gênero - que já foram abordados nesse estudo -, constituíam, cada qual a seu modo, a sua ideia de reinado, de soberano e de súditos, ideia essa que era transmitida às diversas camadas que compunham as sociedades em que se produziram (e que produziam) os fabulários estudados.

Embora possamos defender essa hipótese com mais segurança em relação aos quatro livros abordados durante a feitura deste trabalho, é possível apontar mesmo na tradição helênica construções que corroboram essa ideia. Aqui, contudo, apresentaremos apenas uma fábula de Sindabâd contida nas Cento e uma noites, com o objetivo de ilustrar o que dissemos e, assim, encerrar este estudo:

Rapidamente, o vizir dirigiu-se ao rei e, beijando o solo diante dele, disse: "ó majestade, impõese aos reis que nada façam antes de se aconselharem; o rei deve ser generoso, e não apressado". E recitou os seguintes versos:

"Sede generoso, mas não apressado, e observai o perdão dia e noite; não vos apresseis em matar o rapaz sem que para tal haja motivo e prova"

E, terminados os versos, ele contou a seguinte história:

[o rastro do leão, "Leo"]

Eu soube, ó majestade, que certo rei desejava tudo que via. Certo dia, estando ele num de seus locais de repouso, passou uma jovem de garbo e formosura, e ele a desejou. Determinou que o marido dela fosse enviado a uma missão qualquer e, depois, foi até ela e manifestou o desejo de possuí-la. Ela disse: "sou vossa serva, meu senhor, e tudo que desejardes será feito. Peço-vos, porém, alguns instantes a fim de que eu possa resolver umas coisas”, e, ato contínuo, entregou ao rei um livro que pertencia ao marido, livro esse que continha a condenação dos pecados e da prática de enormidades, além de toda mais sabedoria: "lede este livro enquanto me aguardais", disse-lhe.

O rei abriu o livro e, vendo o que ali se continha de pecados e violações do que é vedado aos homens, arrependeu-se de seu intento, deixou a mulher em paz e volveu ao palácio - mas esqueceu as sandálias na casa.

Quando o marido retornou, entrou na casa e viu as sandálias do rei: percebeu o que era e soube que somente poderiam ter ali chegado por causa de algum envolvimento entre a mulher e o rei. Saiu de casa, pois, sem mencionar o assunto para ninguém, por medo do rei, e não se aproximou mais da esposa, abandonando-a por vários dias, e ela então mandou dizer a seus familiares: "meu marido me abandonou", e eles foram se queixar ao rei dizendo: "tínhamos, que Deus vos aperfeiçoe, uma terra que demos a esse homem a fim de que a habitasse e melhorasse, e ele habitou-a durante longo tempo, mas agora abandonou-a: faz dias que não se aproxima dela. Assim, ou ele torna a habitá-la como dantes ou no-la devolve". Disse o rei ao marido: "o que alegais quanto a isso?” Ele respondeu: "eles disseram a verdade, ó majestade: deram-me uma terra que habitei e melhorei até que, certo dia, nela encontrei vestígios da presença de um leão, e foi por medo dele que não mais tornei”. Disse o rei: "por vida minha que dissestes a verdade: o leão de fato esteve em vossa terra, mas nada fez que vos desgostasse, pois ali topou com um 
fosso que o conduziria ao aniquilamento caso ele a habitasse; por isso, deixou-a; retomai, portanto, a posse de vossa terra, e nada temei”. ${ }^{287}$

A fábula exposta demonstra, de modo bastante sintético, os elementos que discutimos: um rei - associado metaforicamente a um leão -, que precisa ser aconselhado e, de certa forma, guiado para que não cometa erros em seu proceder. Cometendo-os ou não, no entanto, mantemse respeitado e temido por aqueles que compõem o seu reino; ilustra-se, assim, o que se espera de uma sociedade e de seus membros constituintes.

${ }^{287}$ In.: ANÔNIMO. Cento e uma noites - Histórias árabes da Tunisia. Tradução por Mamede Jarouche. São Paulo: Editora Hedra, 2002. 


\section{Conclusão}

Encerrado o estudo, diremos agora, de modo resumido, algumas palavras acerca do que foi possível verificar nesse processo. Conforme anunciamos inicialmente, realizamos a análise detalhada de quatro fabulários, e deles pudemos destacar alguns aspectos.

As fábulas, como pudemos observar, abordam uma série de temas pertinentes ao convívio em sociedade; se algo diz respeito às relações travadas entre os homens e mulheres dos diversos povos e dos diversos tempos, esse algo pode ser objeto de uma fábula, e, assim, é possível encontrar fabulários e fábulas que tratem desde as nuances da amizade até a traição e a vingança, passando ainda por uma série de gradações que envolvem esses e outros assuntos. Não à toa a fábula é associada ao início das civilizações: na medida em que as pessoas passavam a se agrupar, passavam a narrar.

Dentre os temas que a fábula abrange, e, especialmente no recorte realizado, foi possível perceber que a política e os seus liames ocupam espaço privilegiado. A fábula oriental, em linhas gerais, evidencia esse assunto de modo bastante exacerbado, mas, mesmo nos ramos clássicos do fabulário - do qual citamos, por exemplo, as fábulas esópicas -, é possível perceber que o gênero não passa indiferente ao assunto.

Não nos escapou também a verificação de que, conforme a fábula aborda um ou outro tema, lida com uma gama específica de personagens, que denominamos personagens-tipo. Ao tratar de política, por exemplo, a fábula aborda certas posições que entabulam relações e, para ocupar essas posições, elenca determinados animais, pois, também de acordo com as nossas observações, é difícil encontrar uma fábula que trate desse tema e que comporte humanos entre seus personagens. Dizer, contudo, que a fábula que aborda a política opta por animais como personagens-tipo ainda é insuficiente: há, de acordo com as posições, desenlaces e morais que se pretende atingir, o condicionamento de utilização de certos animais em detrimento de outros, ou seja, esse não é um mecanismo de seleção aleatória, mas, sim, condicionado a certos aspectos compositivos desses animais.

Destarte, na referida fábula, é possível encontrar uma variedade limitada de animais ocupando determinadas posições: dentre essas posições, se destacam, costumeiramente, saber 
e poder, e, para ocupá-las, se sobressaem alguns animais. Verificamos então o uso constante de certos animais que podem ocupar a posição de detentor do poder, soberano (em facetas alegóricas dos reis que essas sociedades produzem), e de saber, aconselhador: caso não se respeitem essas regras que, pré-estabelecidas, se atualizam na narrativa, é muito possível que a fábula falhe em seu intento moralizante; assim, o animal que ocupa a posição de poder não deve ocupar, ao mesmo tempo, ou mesmo em outras situações, a posição de saber, e o mesmo é válido para o personagem-tipo que alegoriza a sabedoria.

Com base nesses apontamentos, verificamos então que o leão, costumeiro personagemtipo detentor de poder - poder esse que abarca certas características e condições - não pode ser representado em uma posição de saber, e o chacal, que tão rapidamente identificamos como recorrente na posição de saber, não pode ocupar lugar de poder nas fábulas, sob pena de invalidá-las e, consequentemente, fracassar a tentativa de persuasão que move, se não toda a produção do fabular, uma parte considerável dela. Apesar disso, não apenas o leão pode representar o poder, ou o chacal o saber: há, como já dissemos, uma série de condições e situações que permitem a utilização bem-sucedida de outros animais nessas posições, que devem, contudo, respeitar certas normas. Temos então, para cada posição, uma série limitada de animais, personagens-tipo, aptos a assumi-las sem prejudicá-las.

Pudemos verificar também que, ainda no que se refere aos personagens, sua utilização, embora seja condicionada a uma série de regras, não é estática, pois, cada povo, ao se apropriar desses procedimentos e desenvolvê-los de acordo com as suas características e contextos, pode produzir nuances e efeitos muito próprios. Assim, é possível utilizar o leão, por exemplo, tanto sob os seus aspectos mais positivos de governante, ou mais negativos, de tirano, ou mesmo substituí-lo por um tigre que, ainda felino, ainda de força indiscutível, traz consigo possibilidade de desenvolvimento de matizes outros que servem para melhor retratar aquilo que determinada cultura considera próprio e adequado.

Assim, ao analisar um fabulário não apenas como obra à parte, particular - que ainda assim traria muito de relevante -, mas sim ligado a um contexto de produção, a uma tradição histórica e de disseminação do que acabou por se definir como um gênero literário; ao se respeitar o que há de cada povo nas narrativas, foi possível perceber também modos muito próprios de constituição das fábulas: a recorrência de certos elementos nos permitiu verificar a relevância deles na estrutura da fábula e, além disso, os usos diferenciados a partir do que era recorrente pôde apontar para o aspecto que mantém a fábula, até os dias de hoje, tão atual: a 
capacidade de ilustrar, por meio de exemplos moralizantes, o que quer que seja necessário demonstrar, a quem quer que se pretenda fazer isso.

Ainda pudemos traçar um breve caminho da fábula ao longo do tempo, principalmente na época das obras estudadas, e vislumbrar pontos de contato entre os ramos orientais e ocidentais: possíveis bifurcações de uma mesma árvore/origem - mesopotâmica - apresentam tanto similaridades quanto características muito próprias, tal como, no caso do ramo oriental, a forte relação que estabelece com a religião ou mesmo a estrutura-em-cadeia, e a narrativa "em encaixe”.

É importante dizer ainda que a fábula foi encarada de forma diferente e, consequentemente, recebida de modos bastante dissonantes ao longo do tempo e das culturas: se a cultura greco-romana demorou para assimilá-la como uma composição que não funcionava apenas como meio para atingir a um fim, mas também como fim em si mesma, e chegou até mesmo a associá-la às crianças e aos ignorantes do campo, a cultura indiana desde sempre a desenvolveu de modo bastante generoso e, desde suas raízes, ligada à temas elevamos como a conduta, a política e a religião - talvez porque, em um contexto em que a própria religião indiana apresentava uma série de animais humanizados, não fosse estranho para essa cultura considerar animais vivenciando situações humanas. Os árabes, em contrapartida, receberam a fábula de modo bastante desigual, pois, ao mesmo tempo em que ela se disseminava rapidamente, era criticada pelas suas características ficcionais e desmerecida de possíveis méritos. Tal como entre os povos greco-romanos, demorou até que a fábula fosse reconhecida e valorizada, entre os árabes, mas não tardou até que ela se dignificasse, num processo embrionário do que vieram a ser, inclusive, os espelhos de príncipe.

Chegando ao término de nosso trabalho, concluímos que, embora possamos identificar as quatro obras estudadas como manifestações de um gênero literário - a fábula -, graças à observação de traços compositivos bastante característicos e comuns a todas elas, e, além disso, possamos também elencar uma série de relações bastante interessantes que elas estabelecem entre si na constituição de uma tradição, ao realizarmos a comparação entre elas percebemos também o fato de que, não obstante a todos esses elementos, salta dessa comparação a possibilidade de identificar também aquilo que cada uma delas detém de particular: podemos perceber, com isso, a impressão de um tom peculiar que cada povo atribuiu à sua produção fábular, às suas narrativas, de modo que, assim, nos é permitido vislumbrar o que seriam 
elementos genuínos constituintes de diferentes visões de mundo, ou, como dissemos no início deste trabalho: foi possível apontar o que havia de particular na universalidade do gênero.

A universalidade dos temas tratados nas fábulas, porém, não tem, com isso, sua importância relativizada, muito pelo contrário: perceber que, independentemente da forma como cada cultura e cada tempo trata as suas questões, certos temas são inerentes e demandam um tratamento, demandam soluções e demandam, sobretudo, que se fale sobre eles, somos capazes de perceber o quanto é importante que se mantenha esse conhecimento e que se recorra a ele, posto que tão antigos e tão irremediavelmente atuais. Concordamos então com os apontamentos de Aderson, ao sugerir que "a universalidade dos temas e, sobretudo, a maneira de estruturar as histórias são fatores essenciais para a sua permanência”. ${ }^{288}$

${ }^{288}$ VARGAS, M. V. A. DE M. Do Pañcatantra a La Fontaine: tradição e permanencia da fábula. São Paulo: Universidade de São Paulo, 1990. 256 f. Tese (Doutorado em Filologia e Linguística Românica), Faculdade de Filosofia Letras e Ciências Humanas - FFLCH. Universidade de São Paulo, São Paulo, 1990, p. 232. 


\section{Referências Bibliográficas}

ANÔNIMO. Pañcatantra: Fábulas Indianas - Livro I. Tradução de Marianne Erps Flemming; Maria Valíria Aderson de Mello Vargas; Maria da Graça Tesheimer. 2. Ed. São Paulo: Humanitas, 2004. v. 1

ANÔNIMO. Pañcatantra. Tradução de Édouard Lancereau. Paris: Gallimard/UNESCO, 2006.

ANÔNIMO. Livro das mil e uma noites: volume I - ramo sírio. Tradução de Mamede Mustafa Jarouche. 3. ed. 1. São Paulo: Globo, 2006. v. 1

ANÔNIMO. Livro das mil e uma noites: volume 2 - ramo sírio. Tradução de Mamede Mustafa Jarouche. 2. ed. 1. . São Paulo: Globo, 2007. v. 2

ANÔNIMO. Livro das mil e uma noites: volume 3 - ramo egípcio. Tradução de Mamede Mustafa Jarouche. 2. ed. São Paulo: Globo, 2007. v. 3

ANÔNIMO. Pañcatantra: Fábulas Indianas - Livros II e III. Tradução de Marianne Erps Flemming; Maria Valíria Aderson de Mello Vargas; Maria da Graça Tesheimer. São Paulo: Humanitas, 2008. v. 2

ANÔNIMO. Livro das mil e uma noites: volume 4 - ramo egípcio + Aladim e Ali Babá. . Tradução de Mamede Mustafa Jarouche. 2. ed. São Paulo: Globo, 2012. v. 4

ANÔNIMO. Pañcatantra: Fábulas Indianas - Livros IV e V. Tradução de Marianne Erps Flemming; Maria Valíria Aderson de Mello Vargas; Maria da Graça Tesheimer. São Paulo: Humanitas, 2013. v. 3

ARISTÓTELES. Retórica. Lisboa: Imprensa Nacional - Casa da Moeda, 1998.

${ }^{1}$ CASILDO, G. L. Introduccion general acerca de las fábulas griegas como género literário. In.: Fábulas de Esopo. Madrid: Alianza Editorial S.A., 1998. p.8.

DEZOTTI, Maria Celeste Consolin. A fábula grega: da prática discursiva a gênero literário. Revista Organon. [on-line], v.13, n. 27. Porto Alegre: UFRGS, 1999, julho-dezembro 1999. 
< http://seer.ufrgs.br/organon/article/view/30429/18870 >, ISSN 2238-8915.

ESOPO. Esopo - fábulas completas. Tradução de Maria Celeste C. Dezotti. São Paulo: Cosac Naify, 2013.

FRYE, N. Anatomia da Crítica. Tradução de Marcus De Martini. São Paulo: É Realizações, 2014.

FRYE, R. N. The Cambridge History of Iran: Volume 4: The Period from the Arab Invasion to the. . London: Cambridge University Press, 1975.

HĀRŪN, S. BIN. Livro do Tigre e do Raposo. Tradução de Mamede Mustafa Jarouche. São Paulo: Amaral Gurgel Editorial, 2010.

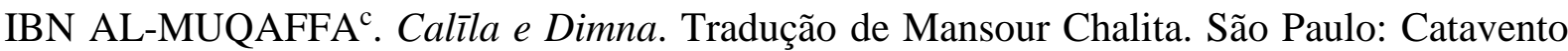
Distribuidora de Livros S/A, 1975.

IBN ALMUQAFFA, A. Kalīla e Dimna. Tradução, organização, introdução e notas de Mamede Mustafa Jarouche. São Paulo: Martins Fontes, 2005.

IBN AL-MUQAFFA, A. Le livre de Kalila et Dimna. Tradução de André Miquel. Paris: Orients; Klincksieck, 2012.

KINOSHITA, S. Translatio/n, empire, and the worlding of medieval literature: the travels of Kalila wa Dimna. Postcolonial Studies, v. 11, n. 4, p. 371-385, 1 dez. 2008.

LA FONTAINE, J. DE. Fables. Paris: La petite collection, 2007.

LA FONTAINE, J. DE. Fábulas. 4. ed. São Paulo: Martin Claret, 2012.

MAQUIAVEL, N. O Príncipe. Tradução de José Antonio Martins. São Paulo: Hedra, 2011.

${ }^{1}$ MUNIZ, M. R. C. em O Leal Conselheiro e a tradição do espelho de príncipe: considerações sobre o gênero. In: PARRILLA, Carmen (org.). Actas del IX Congresso Internacional de La Asociación Hispánica de Literatura Medieval. Noia: Toxo Soutos. 
PERRY, B. E. The Origin of the Epimythium. Transactions and Proceedings of the American Philological Association, 1940, v. 71 p. 392.

PROPP, V. As Raízes Históricas do Conto Maravilhoso. Tradução de Rosemary Costhek Abílio. 2. ed. OP. São Paulo: Martins Fontes, 2002.

RAPSON, E. J. (ED.). The Cambridge History of India: Volume 1, Ancient India. London: Cambridge University Press, 1922. v. 1

SAID, E. W. Orientalismo: O Oriente como invenção do Ocidente. Tradução de Rosaura Eichenberg. 4. reimp. São Paulo: Companhia das Letras, 2013.

SOLALINDE, A. G. Calila y Dimna, fábulas; antigua version castellana. Madrid: Calleja, 1917. 293 p. 29 Disponível em http://www.domíniopublico.gov.br/download/texto/bk000006.pdf >

STEIN, B. The New Cambridge History of India. London: Cambridge University Press, 1990.

THAPAR, R. A History of India: volume 1. New York: Penguin Books, 1990.

TODOROV, T. Introdução à Literatura Fantástica. Tradução de Maria Clara Correa Castello. 4. ed. 1. São Paulo: Perspectiva, 2012.

TODOROV, T. Teoria da literatura: Textos dos formalistas russos. . Tradução de Roberto Leal Ferreira. São Paulo: Editora Unesp, 2013a.

TODOROV, T. As Estruturas Narrativas. Tradução de Leyla Perrone-Moisés. 5. ed. OP. São Paulo: Perspectiva, 2013b.

VARGAS, M. V. A. DE M. Do Pañcatantra a La Fontaine: tradição e permanencia da fábula. São Paulo: Universidade de São Paulo, 1990. 256 f. Tese (Doutorado em Filologia e Linguística Românica), Faculdade de Filosofia Letras e Ciências Humanas - FFLCH. Universidade de São Paulo, São Paulo, 1990.

VERNET, J. Literatura árabe. Barcelona: Editorial Labor, S.A., 1962. 